\title{
O Museu do Estado da Bahia, entre ideais e realidades (1918 a 1959)
}

\author{
Suely Moraes Ceravolo ${ }^{1}$
}

RESUMO: $\bigcirc$ artigo revê a trajetória do Museu do Estado da Bahia de 1918 a 1959, com vistas a identificar as sucessivas práticas museológicas e o engendramento - enquanto se institucionaliza e consolida-se - dos chamados processos de musealização, que estiveram também relacionados à personalidade de gestores e de suas expectativas diante das articulações políticas e sociais, bem como de suas expectativas em relação ao estado da Bahia. Perpassado por conflitos de diversas naturezas, apontam-se as alterações em seu modo de funcionamento. No marco cronológico em foco, caracterizam-se três momentos sucessivos: o da formação como museu histórico; o de consolidação como museu eclético, com olhos voltados para a história, e o caminho em direção à arte, sob a direção de José Valladares.

PALAVRAS-ChaVE: História dos Museus no Brasil. Museologia na Bahia. Museu do Estado da Bahia

ABSTRACT: This article retraces the trajectory of the Museu do Estado da Bahia from 1918 to 1959. The aim is to identify its successive museological practices and the implementation of the so-called processes of musealization during its institutionalization and consolidation, which were also related to the personalities of the administrators and their expectations regarding political and social interactions, as well their expectations toward the State of Bahia itself. Having dealt with a wide range of conflicts, alterations have been observed in how the museum functions. Within the framework in question, three successive periods have been characterized: its establishment as a historic museum; its consolidation as an eclectic museum with a focus on history, and the path towards art under the direction of José Valladares.

KEYWORDS: History of museums in Brazil. Museology in Bahia. Museu do Estado da Bahia.
1. Do Departamento de Museologia e do Programa de Pós-Graduação em História da Faculdade de Filosofia e Ciências Humanas, Universidade Federal da Bahia. E-mail: $<$ suelyceravolo@yahoo.com. br>. 
2.A pesquisa foi desenvolvida no escopo do projeto de pós-doutoramento Matrizes da preservação de bens culturais na Babia (19181959), realizado sob supervisão da Prof. ${ }^{a}$ Dr. ${ }^{a}$ Heloisa Barbuy, Museu Paulista, da Universidade de São Paulo (ago. 2008-ago. 2009). Registro aqui meus agradecimentos à Prof. ${ }^{\text {a }}$ Sylvia Menezes de Athayde, diretora do Museu de Arte da Bahia, à chefe da Biblioteca Maria Helena Povoas Mendes de Souza e sua equipe, e a Josane da Silva Oliveira, pelo apoio e atenção que me foram dados Estendo os agradecimentos à Prof.. ${ }^{a}$ Dr. ${ }^{a}$ Heloisa Barbuy, supervisora da pesquisa de pós-doutoramento e, através de Márcia Medeiros de Carvalho Mendo, à equipe da Biblioteca do Museu Paulista.

3.Ver José Valladares (1946a).

4. Ver Sylvia Menezes de Athayde (1997).

5.Ver Edivaldo M. Boaventura (2004).

6. Cf. Maria Margaret Lopes (1997, p. 12).
Introdução

Sabe-se muito pouco da trajetória do Museu do Estado da Bahia, criado em 1918 e geralmente citado como o embrião do Museu de Arte da Bahia (MAB). Essa lacuna - e, a partir de documentos existentes no $M A B$, a proximidade da figura de José Valladares (diretor de 1938 a 1959) -, incentivou-nos a recuar no tempo para melhor compreender, desde o ponto inicial, o percurso desse que foi o primeiro museu estadual baiano. Nessa retomada, perguntas foram se avolumando, mobilizando a busca por respostas que nos levassem a identificar mudanças e permanências em sua trajetória ao longo de quarenta anos (de 1918 a 1959). Acreditamos que os resultados que ora apresentamos ${ }^{2}$ trazem elementos para apreender os meios pelos quais o Museu se manifestou no espaço social baiano. Dito de outro modo, a procura voltou-se para captar, também, o capital simbólico de que o Museu foi detentor, como resultado de conquistas ao longo de seu processo de institucionalização e consolidação.

É preciso explicar o recorte cronológico, em especial o limite final. Conhecer José Valladares foi o incentivo e princípio da pesquisa, a partir do momento em que vimos registrado seu nome como único representante brasileiro no primeiro número da revista Museum (Unesco), em 1948, e como autor do livro Museus para o povo ${ }^{3}$. Personalidade mais conhecida pelo apoio a uma geração de jovens pintores e escultores baianos, e a salões de arte na Bahia, seu trabalho como diretor do Museu do Estado da Bahia, por duas décadas, ainda é pouco explorado. $\bigcirc$ desenvolvimento da pesquisa foi demonstrando que sua gestão imprimiu novo direcionamento à instituição, a ponto de modificá-la profundamente, realizando uma ruptura com o perfil institucional com que havia the chegado às mãos. Em 1959, o Museu atravessava um período de crise, especialmente por causa de suas instalações, fato denunciado em jornais e do qual, em razão de seu abrupto falecimento, José Valladares não viu a resolução. Sua gestão marcou um ponto de inflexão no direcionamento que o Museu tomou desde então; o que houve depois está relatado sucintamente, por exemplo, em Museu de Arte da Bahia $^{4}$, ou na obra $\bigcirc$ Solar Góes Calmon ${ }^{5}$.

As respostas às nossas perguntas iniciais implicaram dois planos que se conectam: o das práticas museológicas e o das articulações políticas e sociais que deram sustentação ao Museu, ambos vistos em seu contexto cultural. Nessa tessitura, foram engendrados os processos de musealização intimamente relacionados à construção de uma memória social e de patrimônio cultural local, ficando tal processo, no que diz respeito ao Museu, por conta de seus responsáveis, vinculados a correntes de pensamento de seu tempo e dependentes de diretrizes ou expectativas do próprio Estado. Por abordar sucessivos momentos, tal situação motivou nosso interesse, seguindo, como eixo norteador - até onde nos foi possível -, a concepção de museus elaborada por Maria Margaret Lopes, que os entende como "ideais em funcionamento" (ou de instituição) definidos, ou redefinidos, pela dinâmica imposta pela realidade . 
Numa versão já constituída7, o percurso do Museu do Estado da Bahia é apontado como antecessor direto do MAB particularmente por três acontecimentos: o momento fundador, pela lei n. 1255, de 23 de julho de 1918, como anexo do Arquivo Público; posteriormente, pela transferência da coleção ou galeria Abott ${ }^{8}$ para o Arquivo, em 1931, resultando na criação da Pinacoteca e motivando sua abertura (e a do Museu) ao público no Solar Pacífico Pereira; por último, pela compra em 1943, também por parte do estado da Bahia, da coleção e do Solar conhecido como Góes Calmon, fazendo com que o acervo do Museu abrangesse um conjunto suntuoso de objetos e mudasse para novo endereço. Nesse percurso, a direção de José Valladares, iniciada no final de 1938, é - quando citada - sublinhada como condutora de mudanças importantes ${ }^{9}$.

No fluxo da modernização do século XIX e do início do XX, a elite baiana empenhou-se em criar instituições representativas da cultura. $\bigcirc$ Arquivo Público da Bahia foi criado em 15 de janeiro 1890, ano em que a Bahia passou de província a estado federativo ${ }^{10}$; o Instituto Geográfico e Histórico da Bahia (IGHB) o foi em 1894, e, na análise de Aldo José Morais Silva, tratou-se de uma "instituição do saber", constituída "pelas elites e para as elites", funcionando como espaço das letras, do culto ao desenvolvimento, e como promotora da memória ${ }^{1}$. Foi com esses elementos que o IGHB fincou sua presença e a de seus membros, garantindo força e prestígio simbólico frente a uma população em sua maioria analfabeta; e, em razão de sua atuação, realizando a adequação da sociedade ao "ideal de sociedade moderna, civilizada e branca", almejada pela primeira República, mas que ia de encontro à composição étnica da população baiana. Para concretizar e desenvolver essas concepções, a utilidade das instituições foi exemplar, transpassando concepções abstratas para influir nas instâncias práticas da vida social. $\bigcirc$ IGHB foi útil por constituir-se em espaço cultural onde se estabelecia o contato entre segmentos sociais representantes da economia e da política, garantindo com isso a manutenção e o desenvolvimento da teia de relações, o que, por sua vez, afiançava a sobrevivência e a inserção daqueles que estavam nos serviços públicos ${ }^{12}$.

Não é difícil imaginar papel similar para o Museu do Estado, ainda que com outras funções. Instituição subordinada ao governo estadual, esteve à mercê de intenções políticas - entregue à direção de homens destacados para essa função e que, devido à sua formação, faziam parte do grupo social diferenciado, além de balizados por interesses ideológicos que incutiam orientações para o Museu. Na fala de governadores, o Museu do Estado da Bahia surgiu como "necessidade inadiável"13, ligado por um cordão umbilical ao Arquivo, em busca de essência culta, pela preservação de documentos de valor histórico, as "preciosidades" que, bem guardadas, tornavam-no um serviço novo, uma repartição estadual "útil", com alcance para o futuro. Um serviço para os "vindouros"14.

De 1930 a 1940, o empenho político dos grupos de elite na Bahia voltou-se para a retomada do prestígio político, considerado "perdido" em 1930, após o movimento liderado por Getúlio Vargas. Retomar o passado tornou-se uma
7. Como em Sylvia Menezes de Athayde (1997); e em Maria Cecília França Lourenço (1999).

8. Coleção de pinturas formada pelo médico inglês Jonathas Abott, radicado em Salvador e professor da Faculdade de Medicina, composta de quadros de pintores europeus e baianos, adquirida pelo Estado em 1871; cf. Sylvia Menezes de Athayde (1997,p.9).

9. A exemplo de Edivaldo $\mathrm{M}$ Boaventura (2004).

10. Cf. Fábio Paes e Maíta Andrade (1997, p. 14).

11.VerAldo José Morais Silva (2006).

12. Cf.Aldo José Morais Silva (2006, p. 14-15, 59, 129).

13. Ver Antonio Ferrão Moniz de Aragão (1917).

14. Cf. José Joaquim Seabra (1922, p. 71). 
15. Com o movimento de 1930, a Bahia sofreu (com ressentimento das elites) perda de prestígio político. Os intelectuais que se opunham ao governo Vargas organizaram-se na chamada Concentração Autonomista, e A Bahia ainda é a Bahia foi a denominação dada à chapa que reuniu candidatos a deputados federais, em oposição ao interventor Juraci Magalhães em 1933; cf. Paulo Santos Silva (2000, p. 15-16, 145-162).

16. Cf. Hélder do Nascimento Viana (2002, p. 17, 28).

17. Cf. Simona Misan (2005, p. 49-50).

18. Cf. Simon Schwartzman et al. (1984, p. 79).

19. Cf. Paulo Sergio da Silva (2008, p. 41, 115-116).

20.Ver Maria Cecilia Londres Fonseca (2005); Maria Lucia Bressan Pinheiro (2005).

21. Rodrigo M. F. de Andrade, em matéria publicada no Correio da Manbã, Rio de Janeiro, em 12 jan. 1939; cf. Rodrigo M. F. de Andrade (1987, p. 28).

22. Na segunda metade da década de 1940, surgiram o Museu de Arte de São Paulo (1947) e o de Arte Moderna no Rio de Janeiro (1948); ver Alberto Aggio et al. (2002); e Marcos Napolitano (2008). necessidade do presente. A produção historiográfica dessa época - construtora de imagens de um passado idealizado e edificante de uma memória particular - foi expressão desse movimento, encontrando nessa estratégia os meios para a defesa da autonomia política. A intenção era mostrar que a Bahia "era ainda a Bahia", com intensa aproximação entre o plano políitico e a produção intelectual vinculada aos grupos dirigentes locais ${ }^{15}$. A cultura material arquivada no Museu fazia parte desse jogo político, como reforço à identidade cultural local afetada pelas competições políticas entre facções de elites locais ${ }^{16}$. Ambos - cultura material e Museu - foram peças interessantes nesse tabuleiro político.

Outro momento de mudança no percurso do Museu do Estado da Bahia ocorreu após 1934: graças ao vínculo de José Valladares com Rodrigo Mello Franco de Andrade, diretor do Serviço do Patrimônio Histórico e Artístico Nacional (Sphan), o Museu acabou, de alguma forma, alinhado aos objetivos federais. No Estado Novo implantado por Getúlio Vargas, a educação e a cultura prestaram-se diretamente a ser instrumentos de organização social para aplicação das diretrizes do Estado 17. Para um Estado regulador, movido por ideias nacionalistas e de desenvolvimento, a educação e a cultura eram boas ferramentas para construir um povo cujas bases fossem valores como a nacionalidade, a disciplina, o trabalho e a moral. Era preciso modelar um "homem novo", cinzelar mentalidades, cuidar da "alta cultura do país, sua arte, sua música, suas letras"18. A cultura seria elemento de unidade espiritual e, ao mesmo tempo, instrumento para a defesa da pretendida civilização brasileira ${ }^{19}$. Formar mentalidades significou, também, cuidar da preservação dos bens móveis e imóveis, e reafirmar - gosto pelas coisas do país que, por sinal, estavam sendo enviadas para o exterior, fato denunciado por intelectuais ${ }^{20}$. Coube ao Sphan assumir tal projeto. Os museus faziam parte dos planos dessa repartição: os federais, pelo acesso direto; os dos estados, sob forma de colaboração ou apoio, o mesmo valendo para os museus municipais. Todos, idealmente, deveriam valer-se das normas de elaboração de inventários e de catalogação das coleções consideradas de importância a eles incorporadas, com o objetivo de publicar catálogos gerais ${ }^{21}$. Um meio de garantir a não-evasão dos bens para fora do país e dar a conhecer publicamente o patrimônio de bens móveis dos museus.

Política, economia, sociedade e cultura foram se metamorfoseando ao longo do Estado Novo - a redemocratização, por volta dos anos 40, o populismo nos 50 e o desenvolvimentismo no final dessa década e início da seguinte - e cidades foram transformadas pelo surto de urbanização; a indústria, a técnica e a tecnologia foram glorificadas; a população começou a conviver mais proximamente com os meios de comunicação de massa; o rádio se impôs no cotidiano; nascia a televisão; houve florescente produção no teatro, cinema e artes plásticas, e tal conjunção de fatores é tida como propiciatória para o surgimento dos museus de arte no Brasil22. Esse o contexto geral para se redesenhar a trajetória do Museu do Estado da Bahia, cuja dinâmica as fontes utilizadas ajudaram a explicitar. 
Sobre a bibliografia que traz referencias sobre o Museu do Estado da Bahia, encontramos notícias em Silio Boccanera Junior ${ }^{23}$, e em trabalhos do historiador baiano Francisco Borges de Barros ${ }^{24}$, o primeiro diretor do Museu, além de informações em relatórios publicados nos Anais do Arquivo e Museu do Estado. Encontramos outro informe em obra de Laurence Vail Coleman, diretor da American Association of Museums, indicando dois museus classificados como históricos na cidade de São Salvador (Bahia): o do Estado e o do IGHB25.

Outra indicação encontrada foi o guia turístico Beabá da Bahia ${ }^{26}$, publicado num período em que o estado investia na modernização da Bahia, e o turismo já surgia como força impulsionadora. Há, aí, uma nota sobre o Museu, ressaltando a exposição de coleções de "arte antiga local e de arte estrangeira" 27. Ainda como trabalhos que notificam a existência do Museu do Estado da Bahia sem, entretanto, analisá-lo citam-se os de Florisvaldo dos Santos Trigueiros ${ }^{28}$, e Recursos Educativos dos Museus Brasileiros ${ }^{29}$, onde há uma síntese de sua história e informações gerais.

Como parte da série Museus no Brasil, editada pelo Banco Safra, o Museu de Arte da Bahia foi tema de um dos volumes de divulgação ${ }^{30}$, com ênfase nas peças consideradas mais significativas de seu acervo. Na apresentação desse volume há uma pequena referência à criação do Museu do Estado da Bahia no Arquivo Público deste estado. Em Museus acolhem moderno, Maria Cecília França Lourenço teve o objetivo de mapear a arte moderna nos museus brasileiros: o museu baiano surge via pinacoteca, portanto pela arte, retomando como ponto inicial de sua existência a compra da coleção Abott, depois a coleção Góes Calmon; e a direção de José Antonio do Prado Valladares como personalidade ligada ao mundo da $\mathrm{Arte}^{31}$.

Em O Solar Góes Calmon, Edivaldo M. Boaventura delimita duas fases do Museu: a primeira iniciada com a compra do prédio, de 1943 a 1960; e a segunda, de 1970 a 1983. Nesta última, por determinação do governador Luiz Viana Filho, torna-se museu de arte em 6 de novembro de 1970, oportunidade em que a coleção foi "ordenada por especializações", pois, em suas considerações, era até então um museu eclético ${ }^{32}$.

Museu do Estado da Bahia foi examinado de ângulos diferentes nas teses de Helder do Nascimento Viana ${ }^{33}$ e Gabriel Bechara Filho ${ }^{34}$. Em Viana, isso ocorreu em razão de seu estudo sobre os usos da cultura material popular nas coleções e museus na Bahia e Pernambuco. Aqui a abordagem principal foi analisar a construção das identidades culturais locais pelas classes hegemônicas e o interesse do Estado por objetos materiais como elemento simbólico partícipe de lutas políticas, contexto de discussão no qual o museu baiano se insere ${ }^{35}$. Já Bechara Filho trata da construção do campo artístico na Bahia e na Paraíba (1930-1959), focalizando com mais proximidade a Inspetoria de Museu e Monumentos (1927), associada ao Museu do Estado da Bahia e harmonizada
23. Ver Silio Boccanera Junior (1921, p. I-II). Diplomado pela Escola Politécnica do Rio de Janeiro e diretor do Theatro Público S. João, o autor foi membro de várias associações, entre elas a Academia Bahiana de Letras, a Pernambucana de Letras, o Grêmio Literário da Bahia, o Instituto Geográfico e Histórico da Bahia, e clubes ou Ligas de outros estados brasileiros.

24. Ver Francisco Borges de Barros (1928; 1934).

25. Sobre o Museu do Estado da Bahia, o autor apresenta o perfil administrativo, a composição das seções, os nomes do diretor e da publicação,o endereço e horário de funcionamento. Traz também a informação da possível construção - que, de fato, não aconteceu - de um novo edifício para o Museu do Estado; cf. Laurence Vail Coleman (1929, p. 116)

26. Ver José Valladares (1951b).

27. Idem, p. 116-117. Os outros museus aí recomendados por José Valladares foram o do Instituto Histórico, o de Arte Sacra (na Catedral), o do Instituto Feminino da Bahia e o do Instituto Nina Rodrigues.

28. Cf. Florisvaldo dos Santos Trigueiro (1956, p. 84; 1958, p. 185); na publicação de 1956, estão listados cinco museus para o estado da Bahia: o do Estado, o de Arte Sacra da Catedral Basílica, o do IGHB, o do Instituto Médico Legal Nina Rodrigues e o do Instituto Feminino; na de 1958 , há mais dois: o Museu de Arte Popular (do Instituto Feminino da Bahia) e o Museu da Casa dos Sete Candeeiros.

29. Cf. Guy de Hollanda (1958, p. 66-67, 267-268); trata-se de publicação encomendada pela Unesco.

30. Ver Sylvia Menezes de Athayde (1997). 
31. Ver Maria Cecília França Lourenço (1999).

32. Cf. Edivaldo M. Boaventura (2004, p. 49-60, 91-96).

33. Ver Hélder do Nascimento Viana (2002).

34.Ver Gabriel Bechara Filho (2007).

35 . Cf. Hélder do Nascimento Viana (2002, p. 43-44, 129148, 133).

36. Cf. Gabriel Bechara Filho (2007, p.163,165-168, 285286).

37. As concepções de José Valladares sobre museu e museologia, expressas por ele em crônicas publicadas em jornais soteropolitanos, foram apresentadas por Suely Ceravolo e Daisy C. Santos (2007).

38. Ver Anadelia Romo (2009).

39. Ver Anadelia Romo (2010). ao pensamento mais abrangente de preservação da memória artística e cultural do país. Aqui, José Valladares é apresentado como crítico de arte, museólogo 36 e personagem dos mais importantes para a arte baiana do pós-guerra ${ }^{37}$.

Em artigo de sua autoria ${ }^{38}$, Anadelia A. Romo examina o Museu do Estado da Bahia na Era Vargas para perscrutar um momento conflituoso da história desse estado e as disputas sobre representações da cultura afro-brasileira e da cultura popular. Os museus, de modo geral, são compreendidos por Romo como arenas de cultura e de lutas de representação, refletindo um passado idealizado em contraponto às ideologias do presente. Ela defende o argumento de que a política estatal baiana, durante o Estado Novo, encorajou a inclusão da cultura afro-brasileira e, nesse aspecto, o Museu do Estado da Bahia, sob a direção de José Valladares, teve um papel central, funcionando como antítese do que era propagado pelo Museu Histórico Nacional, que dava relevo não à cultura popular, mas às figuras políticas e militares. Ao ousar a junção de representações populares com as elitistas, José Valladares teria sido inovador, mas encontrou obstáculos políticos para levar a bom termo suas ideias. A autora conclui que, provavelmente por pressões, foi levado a silenciar sobre quaisquer aspectos que dissessem respeito à presença do negro na Bahia.

Em Brazil's Living Museum ${ }^{39}$, Romo aprofunda a discussão pendular entre tradição e modernidade (e modernização), tendo como eixo o debate sobre raça desde o ponto de vista da medicina até o dos cientistas sociais, seguido pelo dos antropólogos nacionais e estrangeiros. Nesse campo de tensões, parte da preservação do passado, segundo a autora, deu-se por interesse do Estado, que teve em José Valladares uma espécie de paladino a defender a apresentação de objetos afro-baianos (afro-bahians) na exposição do Museu, situação que se alterou após sua ida para os Estados Unidos.

que se tem, portanto, nesse restrito conjunto de referências bibliográficas são informações de ordens distintas. Dos pontos principais aqui reproduzidos, as obras de Helder Viana, Bechara Filho e Anadelia Romo, ainda que tratem do Museu do Estado da Bahia, não o fazem como um organismo museológico em funcionamento - que é nossa proposta de análise, considerando as atividades que, entendemos, the são próprias. Foi esse o eixo de articulação que procuramos salientar aqui.

O Museu do Estado da Bahia em três momentos sucessivos

Não há como separar a compreensão dos ideais de funcionamento se eles forem isolados das concepções de gestores. Isso, no marco cronológico definido, leva-nos à seguinte sucessão: Francisco Borges de Barros, diretor de 1918 a 1930; Gabriel Ignacio Godinho, de 1931 a 1935, ocasião da constituição da Pinacoteca associada ao Museu; e José Valladares, de meados de 1938 a 1959. 
Na gestão de Borges de Barros, a quem coube o início de formação do Museu - e na continuidade, com Gabriel Godinho -, ele foi sendo delineado, segundo expressões da época, nos moldes de um "museu oficial", para funcionar ao modo dos institutos históricos e geográficos, guardando registros do passado da Bahia e da pátria. A instituição veio à luz como "templo do civismo", com a função de recolher objetos relativos aos feitos, tradições gloriosas e emblemas do heroísmo do povo baiano, que, do mesmo modo, deveriam rememorar e agradecer os "grandes filhos" representados nas estátuas e monumentos das praças públicas na cidade de Salvador ${ }^{40}$. José Valladares teve em mente outro modelo: o dos museus norte-americanos, voltados, como dizia, para "a difusão e a democratização da cultura" ${ }^{41}$. Com esse modelo decorrente dos cursos de especialização que, de 1943 a 1944, realizou nos Estados Unidos, sua gestão distinguiu-se das anteriores. Todavia, não se pode deixar de considerar o condicionamento às ideias que eram concebidas para os museus, emanadas não só do Estado Novo mas, também, do Sphan, que, se não inventou uma filosofia para a salvaguarda de um determinado patrimônio brasileiro considerado histórico e artístico, teve força para agir espalhando-a, ou melhor, nacionalizando-a com autoridade indiscutível por vários estados federativos. Era de se esperar que, na Bahia, fosse sentida a influência de Rodrigo M. F. de Andrade, que via, além do valioso patrimônio arquitetônico, até seus bens artísticos sendo rondados pelos "gringos", visando vendê-los a colecionadores estrangeiros ${ }^{42}$. Nos destinos do Museu, devem ser considerados o carisma, a presença e a influência de Rodrigo e do Sphan, uma vez que José Valladares esteve muito próximo deles, como comprovam correspondências guardadas no arquivo do $\mathrm{MAB}^{43}$.

Em se tratando das mudanças que tiverem efeito sobre os modos de funcionamento, vamos considerátas nos três momentos destacados: o da formação do Museu do Estado da Bahia como histórico; o de consolidação, como eclético, mas com os olhos voltados para a história; e o caminho em direção à arte sob a direção de José Valladares. Mas antes se faz necessário um comentário sobre o encaminhamento do presente texto: o detalhamento a seguir pauta-se em relatórios oficiais, mesmo que os dados, como se acredita, sejam filtrados pelo próprio redator (ou redatores), tal como pode acontecer nas correspondências ou nos livros. Entretanto, mesmo assim, em muito eles elucidam as atividades e a prática museológica interna de museu que, regra geral, vai da aquisição (formação de coleções), pesquisa, documentação e conservação chegando à exposição, qualquer que seja a rubrica que o identifique (história, arte, etnografia, arqueologia, biologia e outras). Nesse movimento (se não dos dias, mas dos anos sob um mesmo diretor) estão as ideias e as práticas explicitando o funcionamento, dando concretude às decisões, às escolhas e seleções, e aos valores atribuídos, que são os fatores significativos para o caminho escolhido, ajustado (ou não) às contingências. Entendemos que não se trata de detalhes, mas sim de elementos explicativos, justamente, da prática cultural de uma instituição inserida no lugar le em tempos sucessivos) onde se desenvolveu e atuou.
40. Cf. Silio Boccanera Junior (1921, p. 64-65).

41. Ver o Prefácio, em José Valladares (1946).

42. Cf. Rodrigo M. F. de Andrade (1987, p. 26); grifado no original.

43. A correspondência entre José Valladares e Rodrigo M. F.de Andrade existente no arquivo do MAB está em pasta sem numeração, sob o título Correspondências Recebidas e Expedidas. José A. P. Valladares para Rodrigo M. F. de Andrade, e cobre o período de 1944 a 1958. 
44. Francisco Borges de Barros é reconhecido no quadro dos historiadores baianos pelo IGHB; cf. Renato Berbert de Castro (1978, p. 185-187); e Paulo Santos Silva (2000, p. 115).

45. Cf. Silio Boccanera Junior (1921, p. 62-63); grifado no original.

46. Cf. Francisco Borges de Barros (1934, p. 574).

47. Cf. Annaes do Archivo Publico (1917, p. 230); grifo nosso.
Arquivo Público da Bahia e o "tabernáculo de honra": a modelagem do museu histórico (1918-1930)

O Museu da Bahia, outra denominação do Museu do Estado da Bahia, foi dirigido de 1918 a 1930 por Francisco Borges de Barros, membro do GHB $^{44}$, que assumiu a direção do Arquivo Público em 27 de setembro de 1915, passando a reorganizá-lo. No ano seguinte, iniciou a reunião de material criando a seção Museu do Archivo Publico. Segundo Silio Boccanera Junior, o museu do Arquivo foi inaugurado em 19 de novembro de 1917, por iniciativa de Borges de Barros, para ser o lugar de guarda de honra de "relíquias" que estavam esquecidas, desconhecidas ou perdidas "a mercê do indifferentismo criminoso de pretéritos governos, e dos homens, também, em geral, nesta terra, por nóssas gloriósas tradições"45. Borges de Barros atribuiu essa criação ao aumento de objetos de valor histórico "em varios ramos da archeologia", fazendo com que, em 1918, o governo do Estado sancionasse lei instituindo o Museu do Estado ${ }^{46}$.

As nofícias de Borges de Barros sobre suas primeiras tarefas no Arquivo nos dão um panorama das condições precárias em que se encontrava esse órgão: era preciso retirar o pó, refazer maços de documentos, encadernando-os com capas de papelão e escrever dizeres para facilitar buscas, solicitar às instâncias superiores mais espaço para guardar coleções de documentos e pedir armários e mobiliário novos para guardar livros e papéis. Nas mesmas instalações do Arquivo, Borges de Barros passou a recolher objetos históricos para formar "um pequeno museu":

Por terem cunho histórico aproveitei o "divan" que pertenceu a D. João VI e obtive de V. Exa. a ordem necessária para mandar restaural-o, e trouxe dos commodos inferiores do Palácio Rio Branco uma peça antiga de finíssima madeira, a qual já se acha nesta Directoria completamente reformada e recolhi duas figuras de mármore. Organizei um pequeno museu para medalhas e moedas, de accordo com o regimento interno da repartição, um outro maior para autographos e documentos importantes e dei inicio a uma collecção de memórias históricas, livros de geographia, chorographia e historia escriptos em nosso Estado47.

Essa declaração, que pode ser compreendida como o ato inaugural do que viria a ser o Museu do Estado da Bahia, esclarece-nos que organizar um museu sob o mesmo teto e espaço era função prevista para o Arquivo a partir de objetos tidos como históricos. Aqui "museu", parece referir-se a conjuntos de determinados objetos - medalhas, moedas, autógrafos, documentos importantes, memórias e livros. Fica subentendido que o mobiliário e a estatuária dele fariam parte.

Enquanto Borges de Barros cuidava de ajeitar um lugar para o museu dentro do Arquivo, o governador Antonio Ferrão Moniz de Aragão, em 1917, compartilhava com seus pares a necessidade de criá-lo tendo como modelos os três grandes museus do período: "Com referência ao Museu, de inadiável 
necessidade, o plano de sua organização está elaborado consoante os mesmos moldes adoptados na instalação do Museu Nacional, do Museu do Ypiranga, de S. Paulo, e do Museu Goeldi, do Pará. De vós depende a autorização para leval-o a effeito" 48 .

O ponto essencial era preservar os chamados "troféus" - representantes de "gloriosas tradições" -, como bandeiras das mais antigas às mais recentes, que contariam uma história bem visível da participação do povo baiano em eventos de dimensão local (tal como Canudos), mas também da monarquia e da República, e outros relativos à vida da cidade de Salvador. Ao lado dos estandartes, figuravam outros objetos guardados, preferencialmente, longe dos olhos. O próprio diretor Borges de Barros escreveu: os "trophéus gloriosos, vivem, se bem zelados, em logares affastados dos olhares dos interessados"49, aproximando as funções de guarda de documentos de um arquivo com o que a mesma significa para um museu.

O Museu do Estado foi criado pela lei n. 1255, de 23 de julho de 1918, e efetivamente inaugurado em 16 de janeiro do ano seguinte, em dia escolhido propositalmente pela comemoração do vigésimo nono ano da criação do Arquivo Público. Entretanto, a cerimônia teve de ser postergada para o dia 21, em razão do falecimento de Francisco de Paula Rodrigues Alves, o Presidente da República. Oficialmente, foi aberto com retratos de personalidades locais, como secretários da polícia, da Fazenda e uma lápide comemorativa em mármore. O novo museu, que substituia o anterior (o do Arquivo), daria para a Bahia e para a Pátria, ao recolher os estandartes de guerra e "relíquias sagradas" consideradas parte do patrimônio histórico da Bahia e do Brasil, um lugar oficial, um "tabernáculo de honra"50, nas palavras de Silio Boccanera Junior, no nível dos institutos históricos. De acordo com Boccanera, o deputado Fiel Fontes apresentou o projeto de criação do Museu do Estado à Câmara Legislativa do Estado em junho de 1918, após visita ao Arquivo Público, onde constatou que ali se guardavam "relíquias do Estado". Teria sido sua sugestão criá-lo como anexo ao Arquivo Público, sob a direção de Borges de Barros, em razão da situação financeira do Estado. No discurso intitulado Museu do Estado - Discurso de Fiel Fontes, reproduzido nos Annaes do Archivo Publico da Bahia (Sessão de 13 de Junho de 1918), o deputado Fontes declarou ter sido influenciado por recomendações de Boccanera Junior, publicadas no jornal Democrata, para que fossem recolhidas as bandeiras espalhadas por igrejas da cidade do Salvador e mesmo em sociedades particulares, o que ficou firmado no artigo 2. da lei n. 1255 de criação do Museu. Em defesa de tal criação argumentou que o Museu traria

progresso do Estado, para aquelles que aqui vierem visitar esta Capital possam admirar o valor da Bahia, que é grande, em tudo, nas artes, na sciencia, e mesmo na occasião em que tem sido preciso demonstrar o seu valor cívico tem sido inexcedível, tem sido extraordinária. Que fiquem nos nossos museus, como patrimônio do Estado, documentos dos nossos antepassados e que isto nos sirva de estimulo para que procuremos cumprir o nosso dever; para que possam coroar de brilho, de dignidade esta tradição; e que as gerações futuras, nos
48. Cf.Antonio Ferrão Moniz de Aragão (1917, p. 17).

49. Cf. Francisco Borges de Barros (1918, p. 294).

50. Cf. Silio Boccanera Junior (1921, p. 64-65). 
51. Cf. Silio Boccanera Junior (1921, p. 64-65); Fiel Fontes (1918, 285-287).

52. Cf. Isaias Alves (1939, p. 123).

53. O artigo 3. revogava as disposições em contrário; cf. Leis do Estado da Babia... (1921, p. 184).

54. Ver Francisco Borges de Barros (1928).

55. Borges de Barros apresenta uma subdivisão da história em: a "história própria", explicando causas e efeitos dos fatos históricos; e a "história especial", de cada nação ou época da história universal A arqueologia seria a "ciência das antiguidades”. cf. Francisco Borges de Barros (1928, p. 1ss).

56. O historiador Luiz Monteiro da Costa, membro do IGHB, escreveu que Borges de Barros tinha qualidades de pesquisador e revelou documentos para a historiografia baiana, mas era, "algumas vezes, confuso"; cf. Renato Berbert de Castro (1978, p. 187).

57. Cf. Francisco Borges de Barros (1928, p. 55-61)

58. Cf. Silio Boccanera Junior (1921, p. 66). fazendo justiça, enveredem pelo mesmo caminho, sigam a mesma rota e a Bahia possa figurar como primeira entre os Estados da Federação Brasileira ${ }^{51}$.

O regulamento foi baixado posteriormente, pelo Decreto 2.220, de 26 de junho de $1920^{52}$.

A lei - composta por três artigos e parágrafo único, assinada pelo governador Antonio Ferrão Moniz de Aragão - estabelecia o Museu como anexo do Arquivo Público sob as seguintes condições: não deveria gerar aumento de pessoal e contrair novas despesas. A mesma lei autorizava a realização de acordos do Estado com sociedades particulares existentes na Bahia, de modo a transferir o que fosse de interesse para a história local, além de acordos com a Arquidiocese para que as bandeiras recolhidas nas igrejas fossem enviadas para a nova instituição ${ }^{53}$.

A concepção de museu de Borges de Barros pode ser depreendida na análise de sua obra Archeologia e História ${ }^{54}$. Para Barros os museus destinavamse ao estudo e à reunião dos monumentos de belas artes, ciências e objetos antigos, e funcionavam como índices "de valores antigos de civilizações extintas e do gráo de sua cultura" que qualquer povo civilizado devia ter; os museus históricos tinham a finalidade de classificar cientificamente e expor ao público os objetos que interessavam à história de um país. De linha positivista, a história "verdadeira" era aquela que relatava o movimento da humanidade e seu progresso nas ciências, artes e indústrias, as revoluções sociais e políticas, a queda dos impérios, a influência das nações, estudando-se suas causas e consequências ${ }^{55}$. Borges de Barros, com seu espírito compilador ${ }^{56}$ incluiu, nessa mesma obra, informações sobre o Arquivo, a Biblioteca e o Museu, comentários sobre a proteção "ás obras de arte retrospectiva", e a súmula do regulamento da Inspetoria de Monumentos Nacionais criada pela lei 2.032 de 8 de agosto de 1927. No trecho Do Museu Histórico do Estado da Bahia está a sequência de seis artigos definindo a finalidade do Museu Histórico da Bahia (O Museu e seus fins): um instituto anexado ao Arquivo Público com o qual constituía uma única repartição, para classificar cientificamente, conservar e expor ao público todos os objetos que interessassem à história da Bahia e do Brasil ${ }^{57}$.

Inicialmente, era formado por três seções: a Histórica, para as bandeiras, troféus, armas e artefatos da Independência e de outros feitos baianos; a Numismática, para moedas, medalhas, papel-moeda, títulos emitidos no país; e a de Antiguidades, que recebia mobiliário, objetos e artefatos indígenas, lápides com ou sem inscrições e "outros objetos cabíveis" 58 . Posteriormente, na obra de 1928, Borges de Barros cita uma seção de História lque deve ter substituído a de Antiguidades) e uma Etnográfica, indicando modificações dez anos após a instalação do Museu, ainda dentro do Arquivo. A leitura das notas publicadas em livros ou a do Regulamento sugere que as alterações no tipo de material colhido ou recebido mudavam a ordem do encaixe classificatório das peças do acervo, levando-nos a supor que, aos poucos, ficava mais evidente e menos generalizado o que correspondia a "objetos cabíveis". Assim, por exemplo, a seção Ełnográfica abre-se para acolher os artefatos indígenas, além dos de uso dos sertanistas e dos 
africanos, ainda que permanecesse a possibilidade de encaixe de "quaesquer outros [...] nesta classificação". Para a seção Numismática, o que muda e fica mais definido é sua amplitude, passando a incluir modelos de apólices do governo, ações e títulos lançados de bancos e companhias, pesos e medidas antigos e modernos ${ }^{59}$.

É longa a lista de objetos que poderiam entrar na seção histórica e, para contar com elementos de comparação entre a concepção de História e a sua materialização no Museu (já que emanadas do mesmo autor, o diretor Borges de Barros), importa apresentá-la. Nela podiam ser classificados: medalhas comemorativas de acontecimentos pátrios, de fatos e prêmios de serviços relevantes; modelos de patentes, cartas e diplomas emitidos por estabelecimentos públicos ou autorizados; modelos de trajes e de "usos da população civilizada"; vestimentas e fardas civis e militares, também antigos ou modernos; bandeiras, armas militares, troféus, petrechos bélicos que tivessem participado de campanhas do exército ou da polícia e os da época da Independência; retratos e bustos de brasileiros notáveis, estampas de edifícios ou monumentos comemorativos de acontecimentos pátrios; cópias de inscrições; fac-símiles; distintivos; utensílios; quaisquer objetos que tivessem valor histórico ou pudessem tê-lo no futuro; telas a óleo; fotogravuras; trabalhos em zincografia sobre assuntos históricos e considerados importantes. Já estátuas, bustos e retratos a óleo de personalidades brasileiras que haviam prestado serviços à Pátria merecendo, por isso, o culto de suas memórias, dependiam de autorização prévia do governador do estado para serem expostos, desde que julgados por uma comissão de pessoas tidas como competentes $^{60}$. $\bigcirc$ conceito de história evolutiva em direção ao progresso e à civilização torna-se, no Museu, a história patriótica, materializada em objetos para atestar os feitos passados, alimentando a memória e enchendo de orgulho as futuras gerações. Na prática, a história aderia-se a objetos emblemáticos relativos a aspectos particulares da história brasileira, nacional e local. Entende-se, nessa modelagem, a proximidade do "culto à tradição", como aponta Regina Abreu, no sentido de enaltecimento de pessoas e eventos exemplares no contexto de uma certa ideia de imortalidade conferida a eles pelos museus, muitas vezes, através das coleções doadas ${ }^{61}$.

Entre o Arquivo e o Museu havia uma perceptível porosidade, ainda que, nos primeiros relatórios, como o de 1919, o que the fosse correspondente não se misturasse a outras seções, como a Indianista ${ }^{62}$ e a de Numismática, ou ao Panteão de Pirajá (incorporado ao Arquivo em 1918)63, sugerindo de relance uma separação definida, com critérios tais que determinados objetos ou seções não se mesclavam. Todavia, essa impressão se desfaz quando se lê a notícia, no texto sobre a seção de Numismática, de que foi acrescentada ao Museu "uma secção de objectos praieiros e sertanistas", na expectativa de aumentar tal seção e "satisfazer a curiosidade dos visitantes"64, dando-nos a dimensão daquela permeabilidade provavelmente decorrente de certa imprecisão quanto àquilo que, de fato, constituiria o Museu. É interessante observar que os objetos etnográficos (indígenas, afro-brasileiros, praieiros e sertanistas) parecem ocupar uma única
59. Cf. Francisco Borges de Barros (1928, p. 55-61).

60. Idem, p. 59-60.

61.Ver Regina Abreu (1996).

62. A seção Indianista constava de um pequeno conjunto de quatro machados indígenas identificados por sua matéria prima (divrite e nephrite), um vaso indígena, e uma flecha dos índios Paxunis; cf. Francisco Borges de Barros (1919, p. 296).

63. No Pantheon do Visconde de Pirajá repousam os restos mortais do general Pedro Labatut ou Pierre Labatut, herói da campanha pela independência (1823), que prestou serviços militares a D. Pedro I, liderou as tropas brasileiras contra as portuguesas que resistiam contra a Independência ocorrida em 1822. Faleceu na Bahia. As lutas para consolidar a Independência na Bahia, tidas como memoráveis, marcam o dia 2 de julho como aquele em que se festeja a Independência na Bahia.

64. Cf. Francisco Borges de Barros (1919, p. 299). 
65. Cf. Annaes do Archivo Publico... (1928, p. 3).

66. Decreto 7.025, de 20 de janeiro de 1931; cf. Annaes do Archivo Publico... (1931, p. 590-591).

67. Cf. Francisco Marques de Góes Calmon (1926, p. 8).

68. Ver Acto (1923, p. II).

69. Cf. Francisco Borges de Barros (1928, p. 75). Isso está no Regulamento do Arquivo Público, Capitulo I, Natureza e Organização item 'l' e 'm', e 'a'e 'b', respectivamente para medalhas e patentes para o Museu Histórico da Bahia; cf. Diario Oficial... (1920, p. 3862 e 3864) categoria: a de "curiosos", isto é, provenientes de culturas outras que não a vigente, excluindo-as da concepção do que seria a moderna cultura baiana. E o Museu era o lugar oportuno para quem quisesse ver esses objetos.

Leis, decretos e regulamentos ora anexavam, ora separavam ou atribuíam novas denominações às seções do Museu, é o caso da Indianista, que, pelo regulamento de 1920, passou à Etnográfica, migrando para o Museu junto com a seção de Numismática e formando com a seção Histórica um grupo de três segmentos. Posteriormente, por força da lei 2.052, de 20 de março de 1928, a denominação do Arquivo e do Museu foi alterada para Museu da Bahia. A reforma do regulamento previa três seções - agora denominadas Arquivo, Museu e Gabinete de Numismática - e mais uma quarta, a seção de "arte retrospectiva e militaria sertaneja", a ser oportunamente montada no Castelo Dias d'Avila, que deveria ser restaurado e incorporado ao patrimônio do Estado seguindo determinação dessa lei estadualos.

Tempos depois, em 1931, a Pinacoteca foi criada por decreto ${ }^{66}$, mas, antes disso, houve a Secção de Pinacotheca, ligada ao Museu desde 1926, segundo a Mensagem do governador Francisco Marques de Góes Calmon, um dos sócios efetivos, fundador do IGHB. Ele fez referência à lei que a instituíra (1.730, de 29 de abril de 1926), e determinava que as telas passariam à Sala do Museu e lá ficariam para incrementar a cultura artística na Bahia, algo indispensável ao progresso do povo ${ }^{67}$.

Havia certa convergência de atribuições entre o Arquivo e o Museu, talvez induzida pela pretendida função científica a ser empreendida por ambos. O Regulamento de 1920, que dava formato às funções do Arquivo Público e Museu do Estado, determinava que a missão do Arquivo era a de salvar da "ruína" as fontes da história da Bahia, adquiri-las ou reavê-las, para isso conservando e executando a classificação sistemática de documentos relativos ao direito público, à legislação, à história e geografia da Bahia ou de outros estados, caso indicados pelo governo estadual ${ }^{68}$. O Arquivo era formado por quatro seções: a legislativa, a administrativa, a judiciária e a histórica. Na seção histórica, segundo o Regulamento, arquivava-se uma série de documentos, entre eles uma coleção de medalhas cunhadas ou a cunhar, as comemorativas dos acontecimentos pátrios, as relativas a prêmios de serviços relevantes, uma coleção de medalhas do Brasil (metálicas ou em papel), e modelos de apólices da província. Exatamente esses itens, até com a mesma redação, foram consignados como atribuições a serem cumpridas também pelo Museu. $\bigcirc$ mesmo regulamento estabelecia que o Museu Histórico do Estado da Bahia, além de formar junto com - Arquivo uma única repartição subordinada à Secretaria do Interior, da Justiça e da Instrução Pública, deveria classificar cientificamente, conservar e expor - com indicações impressas - objetos que fossem de interesse à história da Bahia e do Brasilb9. Aqui, podemos entender que a exigência das indicações revela a intenção de, com a mostra dos objetos, ensinar algo - naturalmente para quem soubesse ler. 
Se havia uma mescla de atribuições entre o Arquivo e o Museu, como a coleta de medalhas e moedas, aspectos distintos os diferenciavam no entanto. $\bigcirc$ Arquivo devia recolher e guardar livros e documentos dispersos, perfazendo uma missão patriótica incômoda, pois levava os funcionários a conviverem com "logares infectos"70, situação que Borges de Barros deixou registrada em relatório. Ao Arquivo cabia também providenciar cópias de certidões, rendendo dividendos para o Estado, e a compra de livros, como obras de "incontestável valor histórico, jurídico, geographico e etnographico"71 e importantes fundamentalmente para o estudo de questões relativas aos limites da Bahia, tema vital e caro ao IGHB. A compra desses livros, por parte do Arquivo, pode ser vista como indício da aproximação com o Instituto; e não se tratava de aquisição aleatória, mas de compartilhamento com a mesma perspectiva de história. Outra atribuição específica do Arquivo era a publicação de documentos em Anais, que seriam divididos, inclusive, pelas três seções do Museu ${ }^{72}$. Por sua vez, a função do Museu era a de guardar as preciosidades que poderiam interessar à História, sendo que a ampliação das coleções ficava sob a responsabilidade do diretor.

As funções, as atribuições do pessoal, o acesso às exposições públicas e os cuidados com o Panteão Labatut foram regimentados em 1920. Ao se ler esse regulamento, estruturado em dois capítulos - o primeiro, sobre o Museu e seus fins; e o segundo, sobre o Pessoal -, percebe-se que as regras estavam claramente constituídas no que diz respeito aos objetivos (classificar cientificamente, conservar e expor), às seções (etnográfica, numismática e histórica) e ao que caberia a cada uma delas, transmitindo-se a ideia de que as normas estabelecidas cobriam as funções gerais esperadas de um museu. $\bigcirc$ mesmo não acontece com as atividades práticas, em que se mesclam ações de natureza mais diversa, levando-nos a pensar que o exercício do dia a dia foi normalizado mais em razão das condições peculiares do trabalho do Museu dentro do Arquivo do que para seguir à risca algum modelo de funcionamento em vigor em outros museus nacionais. As condições locais exigiam adaptações. No tópico das funções "do Contínuo"73, vê-se claramente essa mescla, pelo leque de atividades a cumprir: da solicitação de força policial às normas de visitação; das regras para retirada de objetos ao uso da biblioteca; do recolhimento de objetos eventualmente encontrados nas dependências das salas de exposição à decisão de ministrar palestras por parte do diretor; da publicação dos Anais à nomeação de comissões a serem consultadas sobre a economia e o progresso "do estabelecimento"74.

Ocorre, como vimos acima, que o Museu foi criado somente como um anexo. Sua existência e funcionamento limitava-se a funcionários já existentes no Arquivo, a começar pelo diretor, que acumulava funções. Para trabalhar diretamente no Museu, destinava-se um amanuense; e um contínuo do Arquivo seria deslocado para servir de "contínuo zelador". $\bigcirc$ amanuense, funcionário a quem se atribuíam competências mais especializadas devido a seu grau de formação, tinha o encargo de registrar as ofertas de objetos em livro próprio, distribuí-los nas seções e executar a catalogação, além de cuidar do expediente para o Diário Oficial. $\bigcirc$ "contínuo zelador" ficava com a responsabilidade de
70. Ver Francisco Borges de Barros (1919).

71. Ibidem.

72. Idem, p. 295.

73. Está no artigo 11, do capítulo II do Regulamento do Museu, que trata das funções do contínuo; cf. Diário Oficial... (1920, p. 3864).

74. Ibidem. 
75. Ibidem.

76. Ibidem.

77. Cf. Francisco Borges de Barros (1919, p. 298; 1934 , p. 575).

78. Cf.Antonio Ferrão Moniz de Aragão (1920, p. 69). Em 1937, o Arquivo vagava de "déo em déo" e ainda lutava por um lugar adequado, segundo a declaração de Alfredo Vieira Pimentel, sucessor de Borges de Barros, registrando sua instalação em lugares imprestáveis, antiquados, em ruínas, ainda que, por vezes, sofressem reformas. O Arquivo ocupou espaço na Escola de Belas Artes até 1915, depois parte do prédio do Estado junto à Secretaria do Tesouro e Fazenda; em 1916 foi transferido para o andar térreo de um edifício na Rua Thomé de Souza, na Ajuda; em 1919 foi para prédio arrendado à Associação dos Empregados do Comércio (rua Carlos Gomes, 19) posteriormente vendido ao estado. Pimentel foi enfático ao afirmar que o local era impróprio e escreveu que o Arquivo "carece de um prédio incombustível”, o que garantiria a segurança dos inestimáveis documentos ali guardados; cf. Annaes do Archivo Publico (1937, p. 371). ordenar os armários, de cuidar das coleções e de efetuar a "polícia interna" do Museu 75 . Tratando-se de uma única repartição e ocupando por muitos anos o mesmo espaço físico, os contínuos e serventes do Arquivo trabalhavam inclusive para o Museu. Não havia especialistas, a exemplo do que acontecia no próprio Arquivo; e essa questão não foi resolvida tão cedo.

Nesse período, a pouca discriminação das tarefas do Museu a serem cumpridas pelo amanuense, como os registros de entrada, a catalogação (ou "classificação") e a "distribuição" pelas seções, indicam que, entre a entrada da peça e sua apresentação, ou então sua guarda em algum armário (e vale observar que a responsabilidade de "manter a boa ordem dos armários" era do contínuo zelador, sem que saibamos exatamente a que corresponderia essa tarefa), não havia outros cuidados no trato das coleções. Não se tem referência a nenhum depósito em separado, o que nos faz imaginar, numa tentativa de reconstrução, que esse Museu, dividindo o mesmo espaço do Arquivo, não seria mais do que um mostruário.

Sobre as exposições, nesse mesmo Regulamento, há somente normas, como apontamos acima, relativas aos dias de exposição pública, à informação da existência de um guia das seções, e às penalidades, caso houvesse algum dano às coleções ${ }^{76}$.

As condições de instalação precárias, os poucos funcionários disponíveis, o recebimento de móveis para expor determinadas peças ou estantes para guardar documentos são indícios das difíceis condições de funcionamento entre 1918 a 1930. Por outro lado, as preocupações em estabelecer as normas para seu funcionamento abrem a perspectiva para supor que, em alguma medida, havia interesse do governo em investir no Arquivo e no Museu, no que diz respeito às suas acomodações, a fim de se cumprirem suas tarefas.

A ampliação do acervo, como dissemos, era função atribuída ao diretor do Arquivo e ocorria com a entrada de objetos diversos. Quadros, telas, bandeiras e adereços de bandeiras, pia de pedra, armas, instrumentos bélicos ou musicais, como o tambor e a corneta do 5. Corpo de Polícia, uma fechadura antiga são exemplos de peças que realizavam tal expansão, da mesma forma que peças etnográficas (como as coletadas por Borges de Barros por ocasião de sua viagem à Amazônia e ao Pará), dando mostras de que se mantinha a tendência inicial de coletar objetos considerados representativos da história nacional e local77.

O dia a dia dos trabalhos no Arquivo e no Museu estava imbricado. As dificuldades começavam pelas instalações, o que acarretava sucessivas mudanças de local; e, como o Museu estava no Arquivo, a mudança de um implicava, até então, na mudança do outro. $O$ problema das instalações era tido como do Arquivo, que ia sendo transferido de uma casa alugada para outra, apesar de o governo ter consciência da necessidade de construir um edifício com segurança tal que protegesse os documentos e objetos ${ }^{78}$. Para o Museu, a situação perdurou até a criação da Pinacoteca, em 1931, quando ambos foram instalados no Solar Pacífico Pereira. 
A recomposição das atividades do Museu indica-nos as práticas efetuadas para fazê-lo funcionar, respondendo à missão de ensinar a importância em cultuar o passado. Segundo o Regulamento, os serviços (internos) deviam funcionar das $9 \mathrm{~h}$ às $15 \mathrm{~h}$, correspondendo exatamente aos horários de trabalho no Arquivo. As visitas poderiam acontecer nas seguintes condições: somente em dias previamente determinados pelo diretor, das $11 \mathrm{~h}$ às $2 \mathrm{~h}$ da tarde, com o acompanhamento deste ou do funcionário designado. Nos dias comuns, o Museu podia ser visitado por autoridades, alunos de estabelecimento de ensino acompanhados de seus professores e por pessoas de "alta representação". Nos dias de "exposição pública", correspondentes às datas de 2 de julho, 7 de setembro, 15 e 19 de novembro, as visitas aconteciam se o diretor fosse ordenado pelo governador. Pessoas não decentemente trajadas, menores desacompanhados e os ébrios teriam a entrada negada. Qualquer dano que os visitantes causassem às coleções gerava uma indenização obrigatória pelos estragos, colocando-os sob as regras do Regulamento Geral das Secretarias do Estado. Estava previsto, pelas normas de funcionamento, um "guia das seções" a ser impresso para ser utilizado nas visitas ${ }^{79}$.

Nenhum objeto podia ser retirado do Museu, mesmo que houvesse duplicatas (cuja serventia era a de prestarem-se a permutas). Retiradas só aconteceriam com a autorização do Secretário do Interior, da mesma forma que era do governador do Estado, a instância maior, que dependia a autorização para cópias de telas, passando o ofício de solicitação pelas mãos do secretário do Interior, que o assinaria. Os "empregados do Museu" não poderiam retirar para uso pessoal qualquer objeto "de valor científico" das coleções "feitas" por eles, e deveriam entregar objetos porventura encontrados durante excursões (supõe-se de alunos ou outros visitantes). Quanto às consultas na biblioteca, poderiam ocorrer na sala para visitantes - e somente nela -, desde que o interessado se submetesse às disposições do Regulamento Geral das Secretarias do Estado e do Arquivo. Na dependência do julgamento do diretor ficava a determinação de proferir gratuitamente conferências para o público, com temas relativos às matérias existentes no Museu, e a de promover comemorações para datas nacionais, com prévia anuência do Governo. Os Anais do arquivo e do museu, outra responsabilidade do diretor, apresentariam os documentos "referentes às três secções do Museu, às memórias, aos estudos, às photogravuras e a contribuições outras de interesse para os fins da instituição" 80 , além de trabalhos de especialistas nacionais ou estrangeiros que tivessem realizado algum estudo com peças do Museu. A cargo da direção do Arquivo ficava a manutenção do Panteão Labatut, incluído o pagamento dos serviços do zelador; e os pedidos para pintá-lo ou caiá-lo deveriam ser dirigidos ao Secretário do Interior.

Como repartições estaduais, os serviços do Arquivo e Museu passaram a ser incorporados nas mensagens ou exposições dos governantes, dentro do quadro geral das ações administrativas. De certo modo, isso os oficializava e, ao mesmo tempo, capitalizava-os, em discursos plenos de retórica que criavam, por meio da palavra, o elo entre as funções propriamente técnicas e as boas intenções
79. Cf. Diário Oficial... (1920, p. 3864).

80. Está no Artigo 21, $\int$ único; cf. Diário Oficial (1920, p. 3864). 
81. Cf. José Joaquim Seabra (1922, p. 71).

82. Ibidem.

83. Cf. Francisco Borges de Barros (1922, p. 107-108).

84. O texto sobre a visita e o discurso de Affonso Taunay foi publicado pela revista do Instituto Histórico e Geográfico da Bahia (1928, p. 343 370). Sobre questões envolvendo a derrubada da igreja da Sé, ver Fernando da Rocha Peres (1987).

85. Está no Artigo1. da.Lei 2.052; cf. Annaes... (1928, p. 3-4)

86.Trata-se do Decreto 7.150, de 24 de dez. de 1930; cf. $A n$ naes... (1931, p. 585)

87. Ver Mario Barata (1986). voltadas à história da Nação - postura bastante conveniente para demonstrar a escalada em direção a um almejado aprimoramento cultural. Dois exemplos: o governador J. J. Seabra, no decorrer de 1922, ano da comemoração da Independência, prometeu a instalação definitiva do Arquivo e do Museu numa "Torre do Tombo" soteropolitana, para guardar as preciosidades do passado remoto, ideia que vinha ao encontro dos úteis serviços desenvolvidos pelo diretor, dedicado a reorganizá-los com "boa vontade e carinho"81. Pelo mesmo relato, o Arquivo e o Museu estavam bem instalados, recebendo do governo os móveis apropriados para a guarda de documentos, enquanto as coleções se ampliavam, pelo empenho do governo, recolhendo "objetos de valor" em outras repartições e outros lugares do estado para enviá-los ao Arquivo, ou adquirindo telas para a pinacoteca ${ }^{82}$. Foi igualmente em nome do aprimoramento dos conhecimentos e serviços que Borges de Barros acompanhou o governador J. J. Seabra de norte a sul do país para que observasse as mais "velhas instituições brasileiras", entre elas - Museu do lpiranga, onde foi recebido por Affonso Taunay ${ }^{83}$. $\bigcirc$ governador Francisco Marques de Góes Calmon (1924-1928) foi outro governante que, em suas falas públicas, deu apoio ao Arquivo, ao Museu e, em particular, à questão da salvaguarda do patrimônio histórico e artístico instituindo, em 1927, a Inspetoria de Monumentos Nacionais. Em nome dessa salvaguarda, convidou o confrade Affonso Taunay, historiador e diretor do Museu Paulista, para fazer uma visita à Bahia, numa época em que o IGHB debatia problemas sobre a evasão de bens e outras questões, como a derrubada da igreja da Sé baiana, que estavam em combustão ${ }^{84}$.

A lei que autorizou o governo a reformar o Regulamento do Arquivo e Museu do Estado denominando-os Museu da Bahia ${ }^{85}$, sofreu alteração dois anos depois. Por decreto, passaram a Arquivo Público e Inspetoria dos Monumentos ${ }^{86}$. A decisão foi tomada com base neste argumento: além de ainda não existir material suficiente para constituir um museu em conformidade com seus congêneres do país e que representasse a cultura da Bahia, não havia, naquele momento, como custear despesas imprescindíveis para a organização de um museu. A justificativa para agregar a Inspetoria ao Arquivo foi a de que os serviços que esta prestava ajudavam a coibir a dispersão do precioso patrimônio baiano de arte antiga, e tal acoplamento nos leva a pensar que, por trás dessas decisões, havia aspectos práticos, funcionais e administrativos para que um só organismo centralizasse quaisquer assuntos (e problemas) sobre o patrimônio histórico, artístico e cultural baiano. Contudo, não era de todo estranho que a Inspetoria fosse anexada ao Arquivo - e não se pode esquecer que ao Arquivo ficaram igualmente vinculados o Museu e a Pinacoteca -, pois, a princípio, essa inspetoria executava serviços de proteção de objetos valorizados como históricos ou artísticos. De fato, não era novidade formarem-se "museus especiais" dentro de arquivos, reunindo materiais ou elementos históricos e artísticos, menos para estudá-los do que para constituir "museus ecléticos", segundo Mario Barata, ao analisar as origens dos museus históricos e de arte no Brasil ${ }^{87}$. No sentido inverso, mais recentemente, Ana Cláudia F. Brefe explica que, os arquivos históricos, 
poderiam ser complementos de museus históricos ${ }^{88}$. A reunião de arquivos, museus e bibliotecas pode ser sustentada pelo entendimento de que a função de preservação para construção da História se realizava por meio de documentos, objetos e livros.

É preciso lembrar que o tema do patrimônio como proteção aos monumentos e objetos de valor histórico e artístico contou, desde 1920, com o envolvimento do Estado, fato reconhecido por Rodrigo M. F. de Andrade e relembrado por outros autores ${ }^{89}$, muito em razão da evasão de bens para fora do país. Na Bahia, como apontamos acima, foi criada a Inspetoria Estadual dos Monumentos Nacionais -segundo Borges de Barros, "a primeira no Brasil", instituída pelo governador Francisco Marques de Góes Calmon, na Lei 2.032, de 8 de agosto de 1927, para abrir novos horizontes para a proteção do patrimônio artístico da Bahia ${ }^{90}$. Borges de Barros cumpria sua missão cuidando da história pátria pela via dos documentos e objetos, guiado, assim nos parece, por uma filosofia bastante próxima à do IGHB e pelo espírito de defesa da nação, da memória dos antepassados e da garantia de uma herança para os jovens do futuro. Pode-se supor que sua proximidade com o instituto baiano o tenha incentivado no cumprimento de suas tarefas junto ao Arquivo e ao Museu.

Nessa primeira fase do Museu (1918-1930), a ênfase está na promoção da história, ajustando-se às expectativas locais e, diga-se, seguindo bem de perto a mesma trilha por onde enveredou o instituto local ${ }^{91}$. Todavia, tendo em vista os modelos de museu de história natural tomados como referencia (o Paulista, o Nacional e o Goeldi) ${ }^{92}$, é perceptível, nesse período, o ajuste das coleções do Museu do Estado da Bahia a essas matrizes, como bem sinalizam as mudanças de nome das suas seções em sucessivos decretos. Só em 1931 , depois da conquista de um novo endereço no Solar Pacífico Pereira, no Campo Grande, decorrência também da centralização num só lugar da já citada coleção Jonathas Abott, ficou como tarefa da Pinacoteca centralizar as coleções de arte, compreendidas como telas, enquanto o Museu ia materializando os gestos de patriotismo, de exaltação da nação e de personalidades, com anvência do poder público. As várias limitações de espaço, de funcionários e mesmo de condições de trabalho não parecem ter impedido seu desenvolvimento, em razão do empenho pessoal de Borges de Barros, elogiado, como ja dito, por seu diligente trabalho, nas falas de governadores; e, se dermos crédito às falas oficiais, tendo o apoio do governo.

Conclui-se que a junção, ao Arquivo, da Inspetoria, do Museu e da Pinacoteca formou uma estrutura relativamente coesa para assegurar a preservação dos bens patrimoniais baianos, ao pensar-se em sua salvaguarda e na memória social a ser respeitada no seu tempo e no futuro. $\bigcirc$ ideal de instituição dessa fase ficou mais centrado na coleta e no agrupamento de objetos do que em pesquisas ou exposições para o público. Entretanto, pelo menos no que diz respeito a exposições, isso mudaria no novo endereço do Campo Grande.
88. Cf. Ana Claudia Fonseca Brefe (2005, p. 43, 55).

89. Ver Rodrigo M. F. deAndrade (1987); Mariza Veloso Motta Santos (1992); Maria Cecilia Londres Fonseca (2005); e Maria Lucia Bressan Pinheiro (2005).

90. Cf. Annaes... (1931, p 555 ss).

91.Ver Aldo José Morais Silva (2006).

92. A seção de História do Museu Paulista foi criada oficialmente em 1922; cf. Ana Claudia Fonseca Brefe (2005, p. 23). O Museu Histórico, Nacional nesse mesmo ano ver Regina Abreu, (2001); e Mariza Veloso Motta Santos (2006). Já o Museu Goeldi (depois, em 1931, Museu Paraense Emílio Goeldi), sob a direção de Emílio Augusto Goeldi, teve estabelecidas em 1894, como seções: Zoológica, Botânica, de Etnologia, Arqueologia, Geologia e Mineralogia; cf.Guilherme M. S. M De La Penha (1986, p. 9). 
93. Cf. Correspondência da Loja Mattos para Gabriel Godinho, 30 jun 1931. Arquivo MAB-BA.

94. Cf. Annaes... (1931, p. 589).

95. A aposentadoria de Gabriel Godinho como jornalista foi motivo de noticias em periódicos soteropolitanos em razão de ter sido a primeira moção integral requerida por essa classe de profissionais. Ele sofreu um "insulto congestivo" nas vésperas de 2 de julho de 1935 ; verAposentadoria (1937). Há menção também no Imparcial, 14 nov. 1935. Biblioteca do MAB. Godinho faleceu em 9 de abril de 1943; cf. Relatório das Atividades da Inspetoria de Museu e Monumentos (1943,p.4),Arquivo MAB-BA.

96. cf. Isaias Alves (1939, p.124).

97. Segundo Borges de Barros, houve, anteriormente, iniciada em 1923, a partir do projeto Mansos Chastinet (sancionado só em 1925), uma seção destinada as telas anexa ao museu; cf. Francisco Borges de Barros (1934 p. 576). Não foram encontrados outros comentários que elucidem a natureza desse projeto.

98. Cf. José Valladares (1951a).
Um museu eclético e o espírito cívico (193 1-1938)

Loja Mattos, fundada em 1892

Sapataria e Casa de Modas

Bahia, 30 de Junho de 1931

Ilmo. Snr. Gabriel Godinho

M. D. Encarregado da Pinacotheca do Estado da Bahia

Nesta

Amigo e Senhor

Temos o prazer de accusar o recebimento o officio que sob o No. 98 nos foi dirigido.

A Pinacoteca e o Museu Histórico da Bahia foi, das instituições recentes, a que maiores sympathias obteve de todas as Classes Sociais, uma vez que tem ella a sublime finalidade de insentivar o amor-patrio, avivando o culto das cousas bellas da nossa Bahia e do nosso Brasil.

Desse modo, não podíamos deixar de acquiescer ao desejo de V.S. offertando a "Bandeira Nacional de tamanho médio" para uso d'essa patriotica instituição, o que fazemos sobremodo desvanecidos.

Que os poderes Públicos, continuem entregues ao cuidado carinhoso das bellas cousas e das bôas causas da Bahia, e, terão sempre a nossa satisfação patenteada nos momentos em que nos sejam offerecidas opportunidades.

Queria V.S. acceitar e transmitir ao Exmo. Snr. Dr. secretário do Interior, as homenagens de nossa admiração e os nossos protestos da maior estima e da mais alta consideração.

Somos com prazer, de V.S.

Amos. Attos. e Obrs.

Antonio Franco [...] luy93

Em 1930, Borges de Barros indicou Gabriel Ignácio Godinho ${ }^{94}$ para cuidar da Pinacoteca e do Museu. Sabe-se que foi jornalista e, uma vez aposentado95, a função foi entregue a Antonio de Araújo de Aragão Bulcão Sobrinho e, em seguida, à professora Guiomar de Carvalho Florence, do Instituto Normal da Bahia, também responsável pela Inspetoria até a nomeação de José Valladares em 1938\%6. Nota-se que a junção Pinacoteca, Museu e Inspetoria se refletia confusamente nas expressões que abriam as correspondências não oficiais enviadas a Godinho, identificado ao cargo de Encarregado, Diretor ou Organizador da Pinacoteca do Estado, ou do Museu da Bahia, Museu Histórico, Museu do Estado ou, ainda, Inspetor da Pinacoteca e do Museu do Estado.

A criação da Pinacoteca ${ }^{97}$ teve como objetivo pôr fim à dispersão da coleção Abott. Depois da compra pelo estado, parte desta coleção foi para o Liceu de Artes e Ofícios (antigo Paço do Saldanha), para servir de modelo para aulas de pintura, e parte para o Liceu Provincial, onde haviam ficado vinte e dois quadros, de acordo com as informações de José Valladares ${ }^{98}$. Pelo decreto $\mathrm{n}$. 7.205, de 20 de janeiro de 1931, foi concedida a autorização para o envio das obras do Liceu Provincial (a essa altura, Ginásio da Bahia) e do Liceu de Artes 
e Ofícios para formar a Pinacoteca do Estado, chegando a ela um número reduzido de obras: só chegou o que "sobreviveu"99.

Na concepção de Borges de Barros, ainda responsável pelo Arquivo e, assim, com cargo superior ao do novo Encarregado, a função de uma pinacoteca era a de deixar em exposição as coleções de telas antigas e modernas $^{100}$. No discurso oficial consignado pelo decreto, a abordagem foi outra, legitimando fatores que enalteciam o acervo baiano, ressaltando (como numa escala de valores) a importância da história, os bens e a existência de um conjunto de obras prontas para servir à educação. Os argumentos sobre a história e os bens exaltavam a cidade do Salvador como a capital mais antiga da América Portuguesa, detentora de rica iconografia - "a melhor da América do Sul" 101 -, incluindo a dos templos religiosos, formando um bloco tão significativo que "nem mesmo 60 anos de monarquia e 40 de republica" 102 haviam conseguido reunir, mesmo que espalhadas pelas repartições públicas. A partir desses critérios de valor, a ênfase foi dada à utilidade pública de uma pinacoteca que, da mesma forma que os museus e as bibliotecas, tinham a função de tornar-se índice de evolução e "fino gosto artístico". Uma vez que o Arquivo já vinha reunindo obras há mais de quinze anos, era o momento de apresentá-las para estrangeiros de passagem pelo porto, ou mesmo os "nacionais", a fim de que pudessem ter a medida daquele gosto. Mais um serviço útil.

Com a instalação da Pinacoteca foram criadas novas seções: a Histórica e a Contemporânea, acrescidas da seção Museu Histórico. A cronologia foi o critério para separar as pinturas: as telas constituídas no Império e na República, representativas de fatos da vida política brasileira, da baiana e de "assuntos conexos" iriam para a seção Histórica; e, para a seção Contemporânea, iriam as obras produzidas nos últimos cinco anos, de qualquer natureza e relativas a assuntos brasileiros ou baianos. A seção Museu Histórico abrigaria outra subdivisão, em arqueologia e etnografia. Na subseção arqueológica, poderiam ser "colocadas" armas militares, mobiliários, fardamentos, bandeiras históricas, modelos de navios, velhos candelabros, lustres, colunas de altares, pias de prisões, marcos divisórios de freguesias, fechaduras de casas coloniais, cofres, entre outros objetos. Na etnográfica, os artefatos indígenas lassociando-se o indígena ao passado em perspectiva evolucionista) e a cerâmica "moderna". Segundo as instruções provisórias, poderiam ser incluídas nessa seção fotografias de velhos edifícios dos monumentos nacionais da Bahia, de seus interiores, e dos templos religiosos, ou seja, das igrejas ${ }^{103}$.

Se não havia dúvidas de que as telas e quadros iriam para a pinacoteca, o mesmo não ocorria em relação às subseções arqueológica e a etnográfica. $\bigcirc$ que chama a atenção é a mescla de objetos que, do ponto de vista oficial, poderiam ser recebidos e "encaixados" nessas subseções. Pela letra da lei, material indígena poderia ser oficialmente aceito, mas não objetos de candomblé; contudo eles vão fazer parte do acervo do Museu.

Uma decorrência da criação da Pinacoteca foi a necessidade de obterse outro espaço para abrigá-la e ao Museu. Ainda que se encontrasse em
99. Idem, p. 31ss.

100. Cf. Francisco Borges de Barros (1928, p. 59).

101. Cf. Annaes... (1931, p. 590-592).

102. Ibidem.

103. Idem, p. 593. 
104. Primeiro por um "batalhão de sertanejos" e, depois, por outro de "revolucionários"; cf. Francisco Borges de Barros (1934, p. 575).

105. Em meados do século XIX, o Campo Grande (antes Campo de São Pedro) foi prioridade do governo que, nivelando terrenos, procurou tornar mais fácil o deslocamento da elite que se mudara do centro (agora visto como insalubre) para a arejada estrada da Vitória, região de chácaras e de grandes propriedades de moradias de ingleses; $c$. Consuelo Novais Sampaio (2005, p. 80). Jorge Amado descreve a região da Vitória como o "suprassumo do grã-finismo"; $c$ f. Jorge Amado (1980, p. 72).

106. O dia 2 de julho, envolto em forte simbolismo, era escolhido para marcar acontecimentos políticos ou de outra natureza, a exemplo do lançamento, em 1921, da pedra fundamental do prédio a ser construído para o IGHB; e, em 1923, para sua inauguração; cf Aldo José Morais Silva, (2006, p. 147, 149). Sobre essas comemorações, ver Wlamyra R.Albuquerque (1999).

107. Cf. José Valladares, Relatório sobre as Atividades Administrativas... (7 jul. 1939). Arquivo MAB-BA.

\section{Ibidem}

109. Que estão arquivadas no Museu de Arte da Bahia, sob o título Correspondências do Arquivo do MAB-BA de 1931 a 1934. Pasta Dr. F. Borges de Barros.Anos 1931 a 1934. Correspondências expedidas, s. n. péssimas condições devido às sucessivas ocupações ${ }^{104}$, o Solar Pacífico Pereira, uma antiga residência de dois pavimentos, rodeada de muros e gradis de ferro, localizada na praça Dois de Julho, no Campo Grande n. 11, próxima à área nobre da Cidade Alta ${ }^{105}$, foi conquistado por negociações entre a direção do Arquivo e o governo. Em 2 de julho, dia de festa cívica para a Bahia ${ }^{106}$, Pinacoteca e Museu foram aí inaugurados.

A mudança para um espaço próprio sugere melhores instalações, para ambos, do que as que dividiam com o Arquivo. Anos depois, em 1938, quando se tornou diretor, ainda nas instalações do Solar Pacífico Pereira, José Valladares registrou que o espaço era compartilhado, no primeiro andar, "pela família de um contínuo do Palácio, em cumprimento à determinação do Gabinete da Interventoria"107. Esse não era, entretanto, o único inconveniente: ainda que o espaço fosse amplo e tivesse sofrido reformas e modificações - e aqui cabe o parâmetro das condições apertadas em que vivia o Arquivo -, não era adequado às funções de um museu e suas exposições ${ }^{108}$. $O$ partido arquitetônico do solar, projetado para moradia, tinha seus espaços internos seccionados em cômodos separados, o que nos dá a dimensão do que representou essa mudança. Mas foi ali que a Pinacoteca e o Museu se abriram para a visitação pública - como vimos, bastante sujeita a restrições quando no Arquivo. A localização do Solar junto a uma praça ampla, ornada por monumentos, onde a festa cívica acontecia, facilitava o maior afluxo de pessoas; além disso, por ser esse um ponto de referência para passeios e lazer da cidade do Salvador, garantia maior visibilidade para as instituições então acopladas.

Para recompor aspectos do cotidiano e compreender o funcionamento de 1931 a 1938, pode-se contar com as correspondências emitidas e recebidas 109

Na data festiva, um dia especial, era o momento de envidar esforços para deixar a Pinacoteca e o Museu bem arrumados, com boa aparência e muito material exposto; e, em nome dessa boa arrumação, o Encarregado recorria às lojas da cidade. Foi quando a loja Mattos, respondendo à solicitação de empréstimo de uma bandeira a ser posta na fachada do edifício, doou uma "Bandeira Nacional de tamanho médio", em nome dos serviços "patrióticos" e do incentivo ao "amor-pátrio", indicando-nos a receptividade com que estava sendo acolhida a nova instituição, bem como a partilha com os ideais projetados desde a sua criação em 1918 e, a essa altura, ainda em vigor. Era preciso aprimorar também a exposição e, para isso, recorria-se ao Arquivo e a outras instituições, como o IGHB, a Escola de Belas Artes e o Liceu de Artes e Ofícios, para conseguir mais quadros ou documentos, devolvidos no final do evento com os devidos agradecimentos. Igualmente era necessário aumentar o reforço policial, devido ao afluxo de visitantes, o que era feito com antecedência, e por anos a fio, por meio do Secretário do Estado, da Polícia e Segurança Pública, encaminhando o pedido à Guarda Civil. Expressa nas correspondências consultadas, a civilidade era um dos argumentos usados para assegurar essa colaboração: servir ao Museu era uma maneira patriótica de se apresentar a 
Guarda Civil perante a sociedade e oportunidade para a demonstração pública da moral e da formação intelectual de futuros servidores do Estado, no caso de alunos que se formavam em policiamento. $\bigcirc$ dia da festa cívica, quando visitado por autoridades, alterava ainda mais a rotina do Museu, levando Godinho a pedir o uso do uniforme de gala para os guardas. A festa era oportuna também para convidar a visitar o Museu aqueles a quem tivesse sido encaminhado um pedido ou solicitação, como forma de retribuição ao apoio obtido, sendo os agradecimentos encaminhados posteriormente.

À parte o dia festivo, os pedidos para policiamento eram recorrentes por outros motivos, como para reforçar a segurança, a exemplo da solicitação para enviar mais reforços num domingo em que o Museu seria aberto em caráter de experiência, seguindo o exemplo do que ocorria nos museus do mundo. Como esse trabalho não poderia ser exigido dos funcionários, Godinho e sua família assumiram a tarefa domingueira. Os reforços eram solicitados igualmente quando a situação o exigia, como aconteceu com a derrubada do gradil ao redor do Solar ${ }^{110}$. $\bigcirc$ Encarregado prontamente agradecia e elogiava os guardas por sua presteza e eficiência no atendimento ao público. A relação com a Guarda Civil era bem cuidadosa, ficando a Corporação informada de alterações que porventura ocorressem - troca de guardas ou seu desempenho, suspensão temporária dos serviços, ou mudanças no policiamento diurno e noturno -, e de confiança a ponto de, na sua ausência, a chaves ficarem entregues aos guardas de plantão. Os eventos extraordinários, como arrombamentos ${ }^{111}$, ou do miúdo cotidiano eram também notificados, como é o caso da informação de que a porta lateral do museu seria deixada aberta aos guardas em serviço para que se protegessem das intempéries ${ }^{112}$.

Mas o apoio dessa corporação ultrapassava o policiamento, sendo chamada a auxiliar na manutenção e em reparos, como o conserto de móveis. Das tarefas corriqueiras, havia que cuidar da limpeza do jardim, da manutenção, e providenciar melhorias na edificação, como a instalação de água, o que exigia recorrer a diferentes instâncias administrativas ou, então, criar soluções que dessem conta do funcionamento da infra-estrutura, como sugerir a cobrança da entrada e o recolhimento de tributos devidos ao Estado para consertar o calçamento do entorno. ${ }^{113}$.

A ampliação do acervo é outro fator significativo para se compreender em que moldes ocorriam as práticas museológicas sob a gestão de Gabriel Godinho: os objetos provinham de doações, oferecimentos, transferências, empréstimos e até "estadias" (palavra que dá a entender um empréstimo de prazo curtíssimo, já que para quinze dias ${ }^{114}$ ), e movimentava as entradas e saídas da Pinacoteca e do chamado Museu Histórico. Mais uma vez é a diversidade de objetos que chama a atenção. Podemos deduzir que quadros, telas e esculturas solicitados para a Escola de Belas Artes tinham como destino a Pinacoteca; mas - destino das armas, bandeiras e estandartes, cofres, tinteiros, insígnias, documentos, elementos de decoração os mais variados, esculturas, fotografias e fotogravuras, indumentária e fardas, instrumentos de medição, mobiliário,
110. Ver Correspondências (30 maio 1933). Pasta Dr. F. Borges de Barros.Anos 1931 a 1934. Correspondências expedidas, s. n. Arquivo MAB-BA

111. Fato ocorrido na Pinacoteca na noite de 6 para 7 de abril de 1935 .

112. Ver Correspondências (16 maio 1931). Pasta Dr. F. Borges de Barros.Anos 1931 a 1934. Correspondências expedidas, s. n. Arquivo MAB-BA.

113. Ver Correspondências (15 jan. 1931; 1 mar. 1932; 14 out. 1933,3 jun. 1932). Pasta Dr. F. Borges de Barros. Anos 1931 a 1934. Correspondências expedidas, s. n. Arquivo MAB-BA.

114. Ver Correspondências (3 mar. 1931; 17 jul. 1934). Pasta Dr. F. Borges de Barros. Anos 1931 a 1934. Correspondências expedidas, $\mathrm{s}$. $\mathrm{n}$. Arquivo MAB-BA. 
115. Ver Correspondências (19 set. 1933; [s.d.] mar. 1934). Pasta Dr. F. Borges de Barros. Anos 1931 a 1934. Correspondências expedidas, s. n.Arquivo MAB-BA.

116. Cf. Mario Barata (1986, p. 22).

117. Segundo Ana Brefe, esses museus eram mais voltados para as ciências naturais do que para etnografia ou antropologia; cf. Ana Claudia Fonseca Brefe (2005, p. 51-52).

118. Ver Correspondências (17 set. 1931). A "seção de Zoologia" vai merecer um comunicado enviado ao Secretário do Interior e Justiça sobre o péssimo estado do espaço, dos armários e dos animais, o que leva a Diretoria do Interior e Justiça do Estado a solicitar uma relação das coleções de aves e animais que se achavam "imprestáveis"; ver Correspondências (28 out. 1937). Quanto à coleção mineralógica, ver Correspondências (12 nov. 1937). Pasta Dr. F. Borges de Barros.Anos 1931 a 1934. Correspondências expedidas, s. n.Arquivo MAB-BA.

119. Cf. Francisco Borges de Barros (1928, p. 58).

120. Ver Correspondências (5 maio 1932). Pasta Dr. F. Borges de Barros.Anos 1931 a 1934. Correspondências expedidas, s. n. Arquivo MAB-BA

121. Cf. Ademir Ribeiro Junior (2008, p. 17).

122. Ver Hélder do Nascimento Viana (2002). miniaturas, moedas e medalhas, relógio, retratos e troféus teria sido a parte histórica? É possível perceber que a definição das seções ou subseções - a de arte e a de história, com arqueologia e etnografia - era, na prática, bastante fluida, tanto para a instituição, que recebia as peças, como para os doadores que as enviavam. Um exemplo pode trazer esclarecimentos: sete grandes quadros da Irmandade de Nossa Senhora da Ajuda e Senhor dos Passos foram aceitos e enviados para "galeria religiosa", recebidos pelo "Diretor da Exposição Sacra da Pinacoteca do Estado"115. Para tal amplitude de possibilidades, a "compreensão" do que seria a arte e a valorização dos aspectos artísticos dos objetos pode ter contribuído para o surgimento das pinacotecas e o ensino das academias de belas artes. Essa é a explicação apresentada por Mario Barata, ao analisar os museus de história, e o motivo para que a categoria arte fosse aplicada a objetos indígenas ou artefatos arqueológicos, mesmo nos museus ecléticos no Brasil 116 . Seja como for, se a expectativa era a de constituir um acervo histórico, desde a fase anterior o que se tem, tomando como critério a diversidade de objetos recebidos, só reforça a ideia de se tratar, aqui, da permanência do modelo de museus enciclopédicos, enraizados no modelo dos museus de história natural disseminados no século XIX, e que foi o padrão explicativo para museus também no Brasil ${ }^{17}$. Nesse aspecto, vale lembrar que o Museu Nacional, o do Ipiranga (Paulista) e o Goeldi (todos então museus prioritariamente de História Natural) foram a seguir citados como modelos, no momento do surgimento do Museu do Estado da Bahia, inaugurado em 1918. Teria sido outra a razão para a aceitação de uma "galha de veado", de um "peixe fóssil", enviado por membros do IGHB, ou de uma coleção mineralógica para a "seção de Zoologia" 18 ? De acordo com Borges de Barros, havia uma Coleção de História Natural anexa ao Museu, que serviria para criar um museu específico quando fosse fundado 119.

Por sua vez, não teria sido para alinhar as coleções do Museu às práticas do IGHB que o Encarregado se empenhou em solicitar, diretamente ao secretário da Polícia e Segurança Pública do Estado, objetos "curiosos" de "candomblé", apreendidos em batidas policiais e recolhidos às delegacias ${ }^{120}$ ? Era comum, na Bahia, a repressão direta aos terreiros de candomblé, para prender os participantes e recolher os objetos usados nos rituais, como provas de práticas ilegais, de idolatria e politeísmo ${ }^{121}$, mas não há explicações, na documentação consultada, para as razões de seu aceite no acervo do Museu naquele momento. Para formar esses conjuntos nos museus, há uma situação de fundo, e nos valemos da análise de Helder Viana para o que ocorreu com o recolhimento desse tipo de objeto por parte do instituto baiano e do pernambucano que, no nosso entender, se aplica à situação do Museu do Estado da Bahia' ${ }^{122:}$ não se trata de analogia, mas de diretriz de época, se lembrarmos que a mola propulsora do surgimento dos museus, por parte dos institutos ou por parte do Estado, era acionada pela necessidade de, por motivos políticos, esculpir a identidade regional.

Essa era uma das razões para recolher objetos locais de valor histórico e artístico, dando garantias às respectivas memórias estaduais, além de artefatos 
etnográficos, para ter em mãos demonstrativos da ocupação territorial e humana nacional, o que se tornou praxe inclusive para os museus de história natural ${ }^{123}$. E também "troféus", no sentido de artefatos de índios, negros e mestiços, do homem pobre do campo, de revoltosos, subalternos, desordeiros e incivilizados que resistiam à ordem civilizatória (classe em que se encaixavam aqueles retirados dos terreiros de candomblé pela repressão policial). Com isso, de acordo com Hélder Viana, foram criadas categorias ideológicas e hierárquicas, perfilando os objetos em dois patamares sociais polarizados: de um lado, os objetos referentes à elite (os históricos, os de arte, os "notáveis"), carreando o modelo exemplar de civilização; e, em posição oposta, os "troféus" 124 . Recolhê-los tornou-se uma prática, e a filosofia dos institutos, com força para formar opinião, não deveria encontrar obstáculos para disseminá-la para os museus estaduais, uma vez que o campo daqueles que se lançavam em empreitadas culturais era restrito, as instituições eram poucas e relacionavam-se entre si $^{125}$.

Na busca de dar aos objetos em doação o caráter de testemunhos fidedignos do passado, o "tempo" aparece como atributo a que continuamente se recorria para reforçar tal caráter, havendo, nessa gestão, expressões "temporais" registradas em correspondências - os objetos eram do "período colonial", do "Império", dos "antepassados", do "tempo do pai" - , que agiam como que impregnando-os de uma qualidade específica lque não deixa de ser um dispositivo simbólico) para que indivíduos comuns, através de doações, se sentissem inseridos na história da Bahia e na história pátria. E as doações aos museus não são sem razão. Segundo Solange F. de Lima e Vânia C. de Carvalho, a ação de doar é significativa para o doador, que sabe o lugar social ocupado pelo guardião a quem remete seus pertences, especialmente se o museu acumula objetos que significam algo para uma cidade e para a nação ${ }^{126}$ - regra que, entendemos, aplica-se ao Museu do Estado da Bahia.

Outra qualidade atrelada aos objetos era "primitivo"127, como que tecendo o tempo na mesma trama de um estado de desenvolvimento a ser superado por "civilização". A aceitação de objetos tidos como históricos ou primitivos, de amostras ou espécimes coadunava-se com a matriz enciclopédica dos museus de história natural, apontando, simultaneamente, para uma demonstração de anacronismo, pois nos museus, desde 1920, a tendência temática passou à história e à arte nacional ${ }^{128}$.

Voltando ao cotidiano do Museu, mais uma vez as correspondências nos dão exemplos de membros da sociedade baiana que se dispuseram a colaborar: funcionários públicos (engenheiros, diretores, oficiais, inspetores, encarregados, secretários, provedores), ao lado de associações particulares (como clube carnavalesco), estão nessa lista. $\bigcirc$ alfaiate Rafael da Costa Lima, por exemplo, emprestou "sete quadros de moedas e um dito de cédulas" 129 . Bem mais próximos da sociedade baiana, o Museu e a Pinacoteca ampliavam as coleções, e era de bom tom, por parte do Encarregado, garantir esse elo que alimentava e dava visibilidade à instituição. Vinham a calhar as homenagens ou agraciamentos pedidos às instâncias superiores para honrar determinadas
123. Ver Maria Margaret Lopes (1997).

124. Cf. Hélder do Nascimento Viana (2002, p. 37).

125. Ver Paulo Santos Silva (2000).

126. Cf. Solange Ferraz de Lima e Vânia Carneiro de Carvalho (2005, p. 85-86).

127. A exemplo de um "tembetá dos índios"; ver Correspondências (5 jun. 1931). Pasta Dr. F. Borges de Barros. Anos 1931 a 1934. Correspondências expedidas, $\mathbf{s . n}$. Arquivo MAB-BA.

128. A criação do Museu Histórico Nacional em 1922 teria dado abertura para os temas da brasilidade com ênfase na história e na arte nacionais; ver Regina Abreu (1996).

129. Ver Correspondências (26 jul. 1934); ver Pasta Dr. F. Borges de Barros. Anos 1931 a 1934 . Correspondências expedidas, s. n. Arquivo MAB-BA. 
130. Ver Correspondências (6 ago. 1931); ver Pasta Dr. F. Borges de Barros. Anos 1931 a 1934 . Correspondências expedidas, s. n. Arquivo MAB-BA

131.A título de exemplo: no mês de abril de 1932, foram 752 visitantes; no mês posterior, 941; cf. Relatório para o Interventor Federal então Tenente Juracy Magalhães (24 abr. 1931). O documento está na Pasta Dr. F. Borges de Barros. Anos 1931 a 1934 . Correspondências expedidas, $s$. n.Arquivo MAB-BA.

132. Cf. Annaes... (1931, p. 592-593).

133. Ibidem. pessoas, tornando enaltecidos e públicos os atos de colaboração para com o Museu. A senhora Marietta Pacífico Pereira foi convenientemente agradecida pelas sucessivas doações dos mais variados objetos ao longo de 1931 (maio, junho, agosto, novembro), mesmo que sobrasse para o Museu o encargo de providenciar o transporte ${ }^{130}$. As doações ou promessas de doações vindas de pessoas de destaque social - a exemplo de industriais e comerciantes, ou de um juiz de Direito - eram comunicadas rapidamente ao Secretário do Interior, Justiça, Instrução, Saúde e Assistência Pública.

Sobre a visitação de pessoas de destaque, especialmente no dia 2 de Julho, os dados chegam a impressionar, como ocorreu em 1937, quando o Museu recebeu 2.048 pessoas. Nos demais meses, a frequência ficava em torno de 700 a 900 visitantes $^{131}$.

No que diz respeito à exposição, as instruções provisórias de 20 de janeiro de 1931, dando formato à Pinacoteca, estabeleciam que a coleção Abott teria uma sala única e que nenhum objeto de outra coleção poderia dela compartilhar. A seção histórica receberia o nome de Pacifico Pereira, em honra ao médico baiano, antigo proprietário do Solar; e a seção contemporânea, o de Alexandre Roiz Ferreira, em homenagem ao "sábio bahiano"132. Outro recurso para agraciar, no espaço do Museu, a elite baiana.

Uma preocupação mais ampla com o patrimônio artístico diz respeito à feitura de um cadastro geral das telas e quadros existentes no estado da Bahia, para que houvesse o "conhecimento exacto da existência dessas preciosidades artísticas" 133 , a serem divulgadas para propaganda da Bahia. Tal fato mobilizou Gabriel Godinho a solicitar o envio de servidores para a Pinacoteca, a fim de, a partir de questionário previamente elaborado, poder confeccionar um catálogo geral. Não se tem confirmação se esse levantamento foi realizado; mas, por outro lado, com a criação da Inspetoria, faz sentido essa preocupação com vistas ao mapeamento do patrimônio. Todavia esse é um caso a ser ainda investigado.

A mudança do Inspetor foi assunto comunicado através de ofícios datados de 24 de novembro de 1937, e cópias foram enviadas simultaneamente para várias instâncias administrativas: ao Secretário do Estado da Polícia e Segurança Pública, ao comandante da Guarda Civil, ao Diretor da Penitenciária do Estado, ao Diretor Geral e ao Secretário de Segurança Pública e ao comandante da Polícia Militar do Estado, informando-os de que o engenheiro Antonio Bulcão Sobrinho assumia o cargo de Inspetor de Museu e Monumentos do Estado da Bahia. No mesmo ano em que entrou em vigor o Estado Novo, foi José Valladares quem passou a responder pelo cargo.

As fontes consultadas comprovam que a Pinacoteca e o Museu do Estado da Bahia estavam em plena atividade entre 1931 e 1937, e que o intercâmbio com a sociedade local, através dos pedidos, solicitações e doações (como no caso da Loja Mattos), foi maior. Os registros referem-se à capacidade dessas instituições de captarem as simpatias "de todas as Classes Sociais", guardando cuidadosamente e "com carinho", "as coisas belas e boas" da Bahia. Foi, portanto, uma fase de movimentação intensa e distinta da fase anterior, 
quando o museu esteve voltado para si mesmo e seu interesse alcançava um número pequeno e restrito de visitantes. Pelas correspondências relativas a esta última fase, captam-se as dificuldades, os vínculos administrativos e burocráticos com interventores e suas secretarias, a movimentação da rede de sociabilidade como mecanismo para sustentar o museu ou ampliar suas coleções; infere-se o quadro rareado de funcionários, da mesma forma que a presença do seu gestor administrando as questões diárias. No Solar Pacífico Pereira, as atividades do Museu (e Pinacoteca) ficaram mais definidas e complexas, podendo-se supor, pela quantidade de entradas de objetos, obras de arte, amostras minerais e mesmo de espécimes animais, que as exposições eram, possivelmente, sobrecarregadas, mas, visitadas.

De forma geral, as duas instituições não estão consideradas no quadro daquelas produtoras da historiografia baiana, ao contrário do que ocorria com - IGHB e a Academia de Letras da Bahia. No período de 1930 a 1940, a produção desses dois últimos organismos foi de uma história pautada em biografias (aquelas de expoentes), recolhendo na própria Bahia a matéria para seus trabalhos, com vistas a revelar e definir o grupo social baiano de elite anelado à Nação e à civilização ${ }^{134}$. Não era função da Pinacoteca e do Museu, nesse momento, produzir pesquisas, mas dar continuidade à captação de vestígios para exemplificar a Bahia e a cidade do Salvador em poucas salas que incluíam as particularidades dos sujeitos sociais que ali deixavam seus bens preciosos.

Com a passagem da Inspetoria Estadual de Monumentos Nacionais (ou simplesmente Inspetoria de Monumentos Nacionais) para a Secretaria de Educação e Saúde (Decreto n. 10.744, de 16 de maio de 1939), além da Pinacoteca e do Museu - os três constituindo a Inspetoria de Museu e Monumentos ${ }^{135}$-, o governo da Bahia instituiu, quase ao mesmo tempo, e de forma centralizada, dois mecanismos de preservação de bens culturais de funções diferenciadas mas complementares.

Desde 1930, quando foi instituído no Brasil outro tipo de Estado, trocando sem grandes rompimentos a elite no poder, as questões de educação ganharam espaço no campo centralizador do novo governo, nas palavras de Boris Fausto ${ }^{136}$. A Bahia não se engajou no processo revolucionário: ao contrário, as classes dominantes "conservadoras em toda a sua essência", foram repentinamente apanhadas pela vitória da revolução e receberam o tenente Juracy Magalhães como Interventor (193 1-1937), iniciando o que Consuelo Novais Sampaio identificou como fase de "acomodação" entre as ideias revolucionárias e a oligarquia local ${ }^{137}$. No plano federal, 1937 foi o ano a partir do qual o Sphan, criado no ano anterior, passou a lutar em todo o território brasileiro pela preservação do conjunto dos bens móveis e imóveis de interesse público, vinculados a fatos memoráveis da história do país, seja pela excepcionalidade arqueológica ou etnográfica, seja pelo valor bibliográfico ou artístico, de acordo com a definição de patrimônio nacional do próprio Rodrigo M. F. de Andrade. Sphan pretendia que a ideia de proteção fosse difundida de todas as maneiras possíveis, para incentivar o gosto pelos elementos que geravam admiração: o
134. Cf. Paulo Santos Silva (2000, p. 145ss).

135. Cf. Francisco Borges de Barros (1928, p. 61); e Isaias Alves (1939, p. 123-124).

136. Cf. Boris Fausto (1996, p. 327, 336).

137. Cf. Consuelo Novais Sampaio (1992, 57ss). 
138. Cf. Rodrigo M. F. de Andrade (1987, p. 27-28).

139. Cf. Paulo Sergio da Silva (2008, p. 91).

140. Cf. Marieta Alves (1977, p. 160).

141. A expressão "Casa do Passado" foi usada em reportagem publicada no jornal $A$ Tarde (27 out. 1952). Biblioteca do MAB-BA.

142. Isaias Alves de Almeida, irmão de Landulpho Alves de Almeida (interventor nomeado por Getúlio Vargas de 1938 a 1942), foi idealizador e professor da Faculdade de Filosofia da Bahia (depois incorporada à Universidade Federal da Bahia), inaugurada em 15 de março de 1943 com corpo docente exclusivamente baiano. Aderiu ao Integralismo, por crença na autoridade e na disciplina como fundamentos da construção do nacionalismo e do patriotismo. Estudou na Universidade de Columbia (em 1931), especializando-se em filosofia da educação; ver André L. M. Dias (2008, p. 245-246).

143. Bibliotecas e museus populares estavam previstos no projeto inicial da Diretoria de Cultura e Divulgação do Estado da Bahia, com objetivos mais amplos dos que aqui apresentados; cf. Isaias Alves (1939, p. 125-128).

144. Cf. Gabriel Bechara Filho (2007, p. 166). Ver também Anadelia Romo (2009).
Brasil possuía "joias de arte e monumentos"138. A identidade nacional se relacionava com o "pensar o Brasil", abrindo espaço para a cultura popular que, no entanto, deveria ser alvo de intervenção ou domesticação, e o Estado se tornou - lugar da renovação, da vanguarda, onde ideias seriam aplicadas - desde que não fossem contra o regime ${ }^{139}$. Tal foi o cenário político e ideológico em que José Valladares, em meados de 1938, foi chamado a dirigir a Inspetoria, célula baiana estadual de proteção aos bens históricos e culturais e, com ela, a Pinacoteca e o Museu ${ }^{140}$. Ele iria aproximar-se inevitavelmente do Sphan. Com outra matriz em mente - e, pela primeira vez, uma matriz especializada para trabalhos em museus -, José Valladares, no início de sua gestão, cuidou diretamente de reorientar a "desorganização" que entendia ter encontrado. É o que vamos acompanhar agora.

\section{Museus no Estado Novo. José Antonio do Prado Valladares, a formação especializada e as crônicas para ensinar Arte e Patrimônio: o ideal de funcionamento da "Casa do Passado"141 de 1938-1959}

Não se pode deixar de associar os destinos do Museu do Estado da Bahia aos objetivos da cultura política do Estado Novo. No ano de 1938, foi criada a Diretoria de Cultura e Divulgação do Estado da Bahia, composta pelas seçães de Divulgação e Serviços Culturais, sob a direção de Isaías Alves ${ }^{142}$, com objetivos precisos de divulgar os princípios do Estado Novo sobre turismo, educação e cultura. Na área da educação e cultura, a Diretoria devia responder por obrigações relativas aos aspectos científicos, artísticos, sociais e econômicos do Estado para a Bahia e para a União. Dentre suas atribuições estavam: dirigir a documentação histórica e social; preservar e divulgar o patrimônio histórico e artístico, mesmo de particulares; e promover e dirigir exposições que estimulassem o movimento artístico e cultural. Segundo suas diretrizes, o povo e a arte popular seriam tirados do limbo. Em sua programação estava prevista a realização de exposição etnográfica, ao modo de ensaio sociológico e econômico, para apresentar aspectos diversos da arte popular, recolhendo aquilo que fosse relativo à "capacidade de invenção e habilidade do povo" em locais como feiras livres, fazendas, candomblés, pequenas indústrias, escolas, e entre colecionadores particulares e coleções oficiais. O Museu do Estado da Bahia, com as funções educativa, cultural e cívica, seria o destino final do material recolhido e da documentação fotográfica produzida nesse evento ${ }^{143}$. A passagem do Museu para a Secretaria da Educação e Saúde, em termos administrativos, também referendou um vínculo maior com a missão pedagógica e cultural do governo baiano em relação ao plano federal ${ }^{144}$.

O Estado Novo contava com um projeto de ação assentado na filosofia de uma ordem social a ser posta no lugar da desagregação do mundo moderno. 
Para isso, argumentou Paulo Augusto de Figueiredo em 1941, era preciso identificar a "alma brasileira", e essa era a diretriz para que os brasileiros não se confundissem com outros povos ${ }^{145}$. Tais premissas - fundamentadas em racionalidade, evolução social, intelectual e artística resultando na unidade do país - assentavam-se em duas crenças: a do domínio do meio pelo homem, forjando-o mental ou espiritualmente (representado pelo social, intelectual, artístico e religioso); e a de que o subconsciente e a memória coletiva formavam o esteio da responsabilidade consciente que os historiadores interpretavam cientificamente $^{146}$. A aproximação do passado ao presente criava o ambiente social favorável para normalizar o Brasil internamente, provendo a condição para o homem expandir-se, ou seja, dar vazão às manifestações artísticas, colocandonos em meio às nações civilizadas, sem ficar devendo nada à arte europeia. Aí estava o meio para se alçar o progresso, a almejada evolução ${ }^{147}$. As instituições, inclusive os museus, deveriam, pois, cumprir a missão de corporificar esses ideais e praticá-los.

Em um artigo seu, Mario Barata, como Secretário do Instituto Brasileiro de História da Arte, técnico em museus e formado pelo curso do Museu Histórico Nacional, dá-nos uma ideia do papel dos museus no Estado Novo ${ }^{148}$. Em pinceladas, fala do anacronismo em pensá-los como "lugar de coisas velhas" ou "torres de marfim", sustentando a ideia oposta de que os museus, naquele momento, eram guiados por princípios de eficiência, técnica, especialização, racionalidade e pesquisas científicas e, além disso, contavam com representação e aporte de congressos e associações internacionais específicos ${ }^{149}$. Também traz a notícia de que, no mundo ocidental, vivia-se plenamente o museum-movement. Educar era a forma de, em cada país, os museus contribuírem para as diretrizes da vida moderna ${ }^{150}$, distribuindo cultura às massas populares e estudando cientificamente os objetos. Os museus - então situados no seio da sociedade e não à sua margem - tinham responsabilidade pela melhoria dos homens, formando seu gosto artístico e sua cultura, aperfeiçoando a vida interior das novas gerações, transmitindo-lhes o melhor das gerações passadas. Úteis ao progresso da ciência, pelas pesquisas a realizar, difeririam do cinema por sua objetividade, oferecendo "unicamente ação educativa"; era, de fato, opção melhor do que tavernas e salões de jogo. Ainda que tal movimento fosse pouco conhecido no Brasil, o Sphan - num esforço de zelo patriótico - cumpria esse papel investindo nos museus ${ }^{151}$.

Se antes, muito sob a inspiração do IGHB e de seus mentores, o Museu do Estado da Bahia partilhava o ideal de construção da história pátria reforçando, nessa história, a participação baiana, na gestão de José Valladares não houve como ficar à margem das aspirações "rodriguistas"152, aquelas emanadas de Rodrigo M. Franco de Andrade. As edificações e obras de arte da Bahia tinham sobre si o olhar atento do Sphan e eram bastante valorizadas. Os intelectuais do "grupo do patrimônio" ou "academia Sphan"153 acolhiam os museus como peças importantes para a cultura no Brasil e como recurso para reter a evasão de bens ${ }^{154}$. Tal leva de intelectuais se tornou mentora e idealizadora, inclusive, dos
145. Cf. Paulo Augusto de Figueiredo (1941, p. 133-138).

146. Cf. Influência politica... (1942, p. 342).

147. Cf. A Ordem politica... (1942, p. 403-404).

148. Ver Mario Barata (1942a). Vale observar que dois artigos de Mario Barata (1942a; 1942b) constam da bibliografia de José Valladares (1946).

149. Mario Barata noticia a existência do Office International des Musées, seção especializada do Instituto de Cooperação Intelectual da Liga das Nações, e, ainda, do Congresso Internacional de 1934 , realizado em Madrid, reunindo os diretores e conservadores dos principais museus do mundo, com teses para o trabalho museográfico, além do Board of Education (Inglaterra) e de diversas associações norte-americanas; cf. Mario Barata (1942a, p. 406).

150. São as seguintes tendências da vida moderna que influenciaram na mudança dos museus: a) todos os homens têm o direito e dever de atingir seu máximo, para o que necessitam de cultura, saúde e um ambiente confortável;b) todos os seres e coisas devem utilizar todos os seus minutos e sua capacidade. Devem usar a ciência, a máquina, a organização racional, a especialização e a cooperação, c) todos os homens devem pensar cientificamente, procurar a verdade pelo esforço, ao contrário de julgar possuí-la pela revelação. Devem ter a atitude espiritual de dúvida $\mathrm{e}$ de crítica construtiva. Devem basear sua reflexão em fatos, ter cautela e consciência no que dizem e no que fazem. Devem agir em conformidade com a ideia de que vivem numa civilização sempre em mudança para o melhor; cf. Mario Barata (1942a, p. 407).

151. Barata faz longo relato dos trabalhos do Sphan, in- 
cluindo aquele com os museus; cf. Mario Barata (1942b, p. 327-354).

152. Expressão talhada por Gilberto Freyre, segundo Marcus Vinicios R. Vilaça (1987, p. 5).

153. Ver Mariza Veloso Motta Santos (1992).

154. Cf. Rodrigo M. F. de Andrade (1987, p. 154).

155. Cf. Antonio Candido (2000, p. 207).

156. Para Ângela de Castro Gomes (2004, p. 51), estar inserido no mundo cultural é condição para garantir o estatuto de intelectual, uma vez que as práticas culturais orais ou escritas, introduzem a pessoa assim considerada em "associações, mais ou menos formais, e numa série de outros grupos", que o influenciam e à sua produção. Aceitando essa conceituação, entendemos que José Valladares esteve plenamente in serido no mundo intelectua de seu tempo, pelas suas atividades e suas obras, e pelos laços que criou, comprovados pelas correspondências hoje arquivadas no MAB

157. Cf. Paulo Santos Silva (2000, p. 79). José Valladares nasceu em 1917 e cursou humanidades no Colégio Antonio Vieira, em Salvador; cf. Marieta Alves (1977, p. 160); ver também Renato Berbert de Castro (1994).

158. Cf. Afrânio Coutinho e José Galante de Souza (1981. p. 1332); e Robert C. Smith (1960, p. 435-438)

159. Os pintores citados são Lasar Segall, Portinari, Noêmia, Di Cavalcanti, Santa Rosa, e o grupo do Recife, com Cícero Dias, Luis Jardim, Manoel Bandeira. A exposição foi organizada pelo pintor Cícero Dias, auxiliado por Clarival Valladares, irmão de José Valladares; cf. Gilberto Freyre (1937, p. 348-352). museus, e dos que tinham preparo para criá-los e movimentá-los. Como se vê, houve uma ruptura ideológica e um deslocamento das forças intelectuais para esse grupo que, ao redor do eixo do patrimônio brasileiro, articulava-se por "questão de amizade", tendo como ponto de partida um "grupo de pessoas integradas em certa atmosfera e certo modo de ser"155. Essa rede deu forma, no Brasil, a um determinado "mundo cultural", intensamente alimentado pela troca de correspondência entre seus participantes. José Valladares era integrante dessa rede, mantendo ligações com os mais diversos especialistas - antropólogos, sociólogos, folcloristas, historiadores de arte brasileiros e estrangeiros, pesquisadores, intelectuais, jornalistas, escritores, editores, livreiros, instituições nacionais e estrangeiras, políticos e governantes -, fazendo expandir as relações em várias direções, articulando pessoas e interesses lainda que nem sempre os mesmos, mas dando vigor ao trânsito das ideias e ao campo profissional) 156 .

Para compreender o terceiro momento do Museu do Estado da Bahia como ponto de ruptura frente a trajetória que até então vinha trilhando, faz-se necessário apresentar melhor José Valladares, o diretor que seguiu a rota aberta para a formação e entrada de indivíduos na comunidade intelectual baiana: escolas de referência no secundário, a formação em Direito ou Medicina, a carreira jornalística como início para a dedicação às letras. Escola e jornal eram oportunidades de socialização, e foram a liga para a coesão de grupo que atingiu postos importantes na Bahia nas décadas de 1930 a 1940157. Ao estudar Direito no Recife, iniciou a carreira jornalística no Diário de Pernambuco ${ }^{158}$, convivendo de perto com Gilberto Freyre, que o chamou para participar como secretário geral do 1. Congresso Afro-Brasileiro (Recife, 1934). Para esse evento, foi organizada uma exposição de objetos afro-brasileiros e de pintores brasileiros ${ }^{159}$. Na correspondência consultada (até por ser posterior ${ }^{160}$ ), não há indicações sobre ter ou não sido a primeira vez que o jovem José Valladares entrou em contato com a arte. Entretanto, se as questões de arte não foram assunto de relevo entre ele e Gilberto Freyre naquele momento, depois serviram de motivos para comentários, quando enviava suas publicações ao mentor pernambucano ${ }^{161}$.

Ao voltar para a Bahia, assumiu os trabalhos da Inspetoria, sem se restringir a ela. Foi ganhando terreno como cronista e crítico de arte, organizador de salões de arte moderna em Salvador, amigo, incentivador e divulgador do grupo de artistas modernos da Bahia ${ }^{162}$, professor de Estética na Faculdade de Filosofia da Bahia, e ativo colaborador do Sphan. A arte foi o tema predominante nas mais de duas centenas de crônicas que escreveu, exercendo sua divulgação e crítica.

Acreditamos que a ida de José Valladares para os Estados Unidos, de 1943 a 1944, tenha mudado, ou reforçado, sua aproximação com as questões de arte no Brasil, pois lá, além de cursos e estágios realizados, passou a conviver com Robert Smith, seu supervisor do programa de estudos e expert em arte colonial latino-americana e portuguesa, com quem passou a se corresponder assiduamente como amigo ${ }^{163}$. A "América" foi um mundo surpreendente, apresentando-se como experiência da qual pretendeu tirar o maior proveito ${ }^{164}$. Os cursos de arte e os 
treinamentos realizados, o que viu em termos de organização e de coleções, a proximidade com Robert Smith, tudo isso aponta para a forte possibilidade de que a viagem tenha se transformado num marco decisivo de mudanças. Estudar a arte brasileira tornou-se um objetivo, seguindo o método "histórico-crítico" para dar ao estudo cunho científico - posição afinada aos propósitos da "academia Sphan" -, e o levou a produzir obras comentadas e incentivar a produção de monografias sobre aspectos específicos da arte, fator que conduziria a Bahia a ultrapassar a imagem atrelada à sua arte colonial ${ }^{165}$.

Detemo-nos, rapidamente, nessa fase de estudos, pois ela mostra a formação do seu repertório especializado e explica o modelo de museu que Valladares trouxe consigo e esforçou-se por implementar. Em sua volta ao Brasil, ensinar arte para os baianos usando o caminho das crônicas foi uma função assumida por ele para atualizar seus conterrâneos e vencer as distâncias, verdadeiras ou imaginadas, entre a Bahia e o sul do país ou o exterior.

A formação especializada e as crônicas para ensinar Arte e Patrimônio

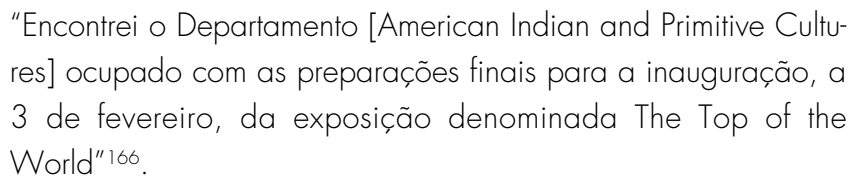

José Valladares

De setembro de 1943 a outubro de 1944, José Valladares cumpriu extenso programa de especialização nos Estados Unidos, propiciado por apoios institucionais relevantes ${ }^{167}$. Desse programa, fizeram parte cursos sobre história da arte, estágios práticos e um roteiro de visitação a museus e casas históricas ${ }^{168}$. Do relatório preparado para o governo baiano ${ }^{169}$, extrai-se todo o conjunto de atividades e treinamento, o que nos dá uma visão do preparo técnico que adquiriu, constituindo fator que o distingue de seus antecessores no que diz respeito à profissionalização pessoal e à especialização para a gestão do Museu.

plano de estudos que Robert Smith e Laurence V. Coleman ${ }^{170}$ the sugeriram foi realizado em etapas (de 30 de outubro de 1943 a 20 de setembro de 1944) ${ }^{171}$, a serem cumpridas parte em cursos e parte em treinamento. Os cursos foram ministrados no Institute of Fine Arts (da New York University); as conferências, no Metropolitan Museum; e o treinamento no Brooklyn Museum.

$\bigcirc$ repertório adquirido nos museus norte-americanos trouxe-lhe uma visão ampla das peculiaridades "dos métodos de exibição, etiquetagem e atividades educacionais" 172 , das formas pelas quais esses museus conseguiam abranger vários ramos do conhecimento, e dos meios empregados para ensinar arte, ciência e história. Os cursos eram criteriosamente escolhidos, para que tivessem serventia para os museus em nosso país, pois era preciso "estudar
160. Pasta Dr. José Antonio do Prado Valladares, Correspondências Recebidas e Emitidas,Anos 1944 a 1954, pasta s. n.Arquivo MAB-BA,

161. Entre outros livros, José Valladares enviou a Freyre: Museus para o Povo (1946); Dominicais. Crônicas de Arte (1951); e o relativo à Galeria Abbott, também de 1951.

162. Cf. Mario Cravo (2001, p. 121-125).

163. Robert Chester Smith (1912-1975) dedicou-se à pesquisa da arte e da arquitetura (portuguesa e brasileira). Lecionou na Universidade da Pensilvânia entre 1947 e 1975, foi Curador do Archive of Hispanic Culture, da Biblioteca do Congresso, em Washington. José Valladares deixou nele tão boas impressões, que Smith declarou ter seu estágio como a melhor experiência com estudantes latino-americanos; ver Correspondências (22 dez. 1944); ver Dr. José Antonio do Prado Valladares. Correspondências Recebidas e Emitidas. Anos 1943-1958, pasta 04.Arquivo MAB-BA.

164. Carta a Odorico Tavares, diretor do jornal Estado da Bahia, em Correspondências (26 jan. 1944); Dr. José Antonio do Prado Valladares. Correspondências Recebidas e Emitidas. Anos 1943-1958, pasta 04.Arquivo MAB-BA.

165. Há uma obra de José Valladares (1960), em que ele procura demonstrar que havia estudos de arte em nosso país e linhas de contato com o exterior, pelas referências existentes em autores estrangeiros (693 entradas); na edição anterior (1955), ele citava 506 entradas.

166. Ver José Valadares, Relatório de Viagem (2 fev. 1945). Correspondências 1945-1949. pasta s. n. Arquivo MAB-BA.

167. José Valladares agradece o apoio do represen- 
tante William Berrien da Fundação Rockefeller, do general Renato Aleixo pelo governo da Bahia, e de Isaias Alves, diretor da Faculdade de Filosofia; ver o Prefácio, em José Valladares (1946a). As atividades desenvolvidas nos Estados Unidos foram apresentadas em conferência na Faculdade de Filosofia, e mereceram duas publicações $(1945 ; 1946 a)$.

168. No roteiro estava o Buffalo Museum of Science, dirigido por Chauncey J. Hamlin, mentor para a criação do Conselho Internacional de Museus (Icom), o que pode ter sido a porta para José Valladares participar, em 1948, da Comissão Editorial da revista Museum.

169. Ver José Valadares, Relatório de Viagem (2 fev. 1945). Correspondências 1945-1949, pasta s. n. Arquivo MAB-BA.

170. Membro do Smithsonian Institution; presidente da American Association of Museums.

171. Na volta para o Brasil, depois de passar pelo México e Peru, aproveitou para conhecer a cidade de São Paulo, onde visitou o Museu Paulista (Museu do Ipiranga) e a Pinacoteca de São Paulo. No Rio de Janeiro, cidade que já conhecia, visitou o Museu Histórico Nacional, o Nacional de Belas Artes, o Museu da Cidade e, em Petrópolis, o Museu Imperial.

172. Cf. José Valladares, Relatório de Viagem (1945, p. 2, 9). Correspondências 1945 1949. pasta s. n. Arquivo MAB-BA.

173. Ibidem. Aí, José Valladares relata ter deixado de frequentar, no primeiro período de seu estágio, o curso History of Research in the FineArts, em razão de tratar de Antiguidade Grega-Romana, Oriente Próximo e Idade Média, sem relação com a arte brasileira. Na elaboração de questões que pode[ria]m surgir nos problemas de arte brasileira", critério que o fez escolher ou desistir de cursos que nada tinham a acrescentar para a arte no Brasil173.

Sobre as técnicas em museus participou de cursos e de treinamento intenso, com aulas expositivas, palestras ou conferências em museum training, em parte ministradas no Metropolitan Museum, versando sobre historia da arte, museus e coleções, documentação, arquitetura de museus, exposição, segurança, administração, serviços educativos, conservação, restauro e o arranjo dos então chamados "depósitos", ampliando ainda mais seus conhecimentos nas visitas realizadas a outros museus. Ressaltamos, em particular, seu aprendizado sobre o que hoje chamamos de expografia, ao ter contato com a filosofia e influência de Wilhelm Boden ${ }^{174}$ para a criação de "quartos de época" (period rooms) e "instalações compósitas", além de métodos de instalações expositivas, entre outros aspectos relativos a esse assunto. No Brooklyn Museum, como tarefas decorrentes das formalidades do estágio, prestou alguns serviços: limpou coleções, numerou objetos, praticou catalogação e registro de objetos, diagramou mostruários e mobiliário expositivo (executando sua instalação), enfim, exercitou a parte prática das atividades de museu.

Foi uma fase produtiva e elogiada. Rodrigo ficava a par do andamento dos trabalhos e ia tecendo comentários nas correspondências que trocava com Valladares, assim se manifestando:

Creio que ninguém ainda, entre nós, terá correspondido tão pronta e brilhantemente quanto você à espectativa das instituições que concedem a brasileiros bolsa de estudos no estrangeiro. Estou certo de que a influência de suas publicações e conferências sobre questões que nos competem já terá sido muito proveitosa e será cada dia obra mais benemérita ${ }^{175}$.

A Bahia ganhava um especialista em museus ${ }^{176}$ - e o Sphan, depois, um colaborador prestimoso.

A arte e o patrimônio histórico e artístico nacional conjugaram-se na vida de José Valladares e foram fontes de reflexão e críticas em alguns de seus escritos. As crônicas tinham a função de incentivar o progresso cultural, informando - público leitor sobre temas do mundo da Arte: história, artes plásticas, arte moderna, artistas plásticos e personalidades desse universo, estética, exposições, falsificações, restaurações, museus, galerias. Enfim, noticiando o que circulava nos debates então contemporâneos. Por exemplo, em Crônica de aniversário, publicada em 8 de maio de 1949, ele explicita que a seção Artes Plásticas tinha o objetivo de familiarizar o público com problemas fundamentais de História da Arte, Crítica e Estética, apontando exemplos ilustrativos da "evolução do pensamento e gosto artístico"177. Atualizado nas novidades e continuamente informado sobre as mais recentes publicações no Brasil e no exterior, justamente por participar do círculo de intelectuais do patrimônio, posicionou-se criticamente diante de uma Bahia que julgava em atraso, o que lhe causou conflitos entre o amor por sua terra, como declarou nessa mesma crônica, e a defasagem que considerava haver em relação a outros estados brasileiros ${ }^{178}$. 
A "substância Sphan" ou o modo de lidar com as questões de arte, arquitetura e cultura desse órgão federal, resultante de trabalhos investigativos daquele serviço, mostra-se plenamente presente nesses escritos, particularmente em notas que se referem à defesa do patrimônio cultural baiano ${ }^{179}$.

José Valladares conquistou sua parcela de prestígio associando arte e patrimônio ${ }^{180}$. Parte desse prestígio deve-se à sua atividade como diretor do Museu do Estado da Bahia, concebendo-o dinamicamente, para atuar como propulsor de ensinamentos e atividades que movimentassem a vida cultural da cidade do Salvador. Às suas mãos chegou um conjunto de peças ecléticas e blocos constituídos - como a coleção Abott, com inflexão na pintura, e a coleção Góes Calmon, nas artes decorativas. As duas coleções eram conhecidas e foram elevadas à condição de signos da cultura baiana. Abria-se a possibilidade de agir e, assim, mudar completamente o direcionamento do Museu. Ele tinha planos, e sonhos. Entretanto, não foi simples enfrentar contingências ou circunstâncias decorrentes de decisões políticas ou administrativas superiores e, ao mesmo tempo, fazer funcionar o Museu nos moldes em que aprendera.

\section{José Valladares e o ideal para o funcionamento da "Casa do Passado"}

"O ano de 1939 foi, por excelência, um ano de organização." 181 "Vamos ver o que acontece com nosso sonhado Museu..." 182

José Valladares

trabalho de José Valladares no cargo de Inspetor de Museu e Monumentos respondia por duas funções: a de inspetor propriamente dita, para fiscalizar, por meio de vistorias, o embarque para o exterior de peças nacionais que tivessem valor histórico ou artístico; e a de diretor do Museu. Fixamo-nos na função de diretor, iniciada pela reorganização do Museu que, em 1938, ainda ocupava o Solar Pacífico Pereira, no Campo Grande.

Das informações colhidas na documentação existente no MAB, priorizamos aspectos que refletem ora as dificuldades que ele encontrou para implantar seu programa de ação, como aconteceu com o regulamento, ora os trâmites da prática museológica, envolvendo questões de administração e de curadoria, da acomodação física do Museu, de atividades de documentação e ampliação de acervos, além daqwuelas de conservação, exposições e funções educativas. seu programa, foi desaconselhado por Walter Cook, diretor do Institute of Fine Arts (New York), de participar de um curso de Antropologia Geral, pelo pouco tempo de que dispunha.

174. Durante as primeiras décadas do século XX,Wilhelm Boden foi diretor da Gemälde Galerie, de Berlin, e teve repercussão internacional por suas pesquisas teóricas e propostas de remodelação. Para exposições em museus, priorizou o arranjo de acordo com o aspecto estilístico, em defesa do que julgava serem critérios mais técnicos; cf. Maria Bolaños (2002, p. 45-46).

175. Rodrigo M.F.de Andrade para José Valladares, 18 out. 1946. Arquivo MAB-BA.

176. A qualidade do estágio americano de José Valladares fez com que criasse (e conservasse) vínculos com instituições norte-americanas, razão de ser chamado a dar pareceres sigilosos para a John Simon Guggenheim Memorial Fondation, em relação a pretendentes brasileiros à bolsa de estudos nos Estados Unidos (como Regina Real, Mario Cravo Junior, George Julien Simoni); cf. correspondência de Henry Alen Moe, Secretário Geral da Fundação NY para José Valladares; 5 mar. 1948; ver Dr. José Antonio do Prado Valladares. Correspondências Recebidas e Emitidas. Anos 1944-1954, pasta 06, Arquivo MAB-BA.

177. José Valladares, Crônica de aniversário, 8 maio 1949. Recortes de Jornais, I.Artigos de José Valladares. Biblioteca MAB-BA.

178. A declaração de atraso da cultura baiana em relação a outros estados brasileiros ou países no exterior aparece em crônicas como As bibliotecas da Bahia ( $A$ Tarde, 5 out. 1946); ver Recortes de Jornais. Artigos de José Valladares, I. 1945-1951. Biblioteca do MAB-BA. 
179. Os conjuntos de notas sobre o patrimônio arquitetônico baiano ilustradas com fotos de sua autoria ou de fotógrafos baianos foram dois, publicados no jornal $A$ Tarde, com os sugestivos títulos de Conhece Tua Cidade e Bahia Ameaçada (final de 1958, a início de 1959); ver Recortes de Jornais. Artigos de José Valladares, II. 1945-1951. Biblioteca MAB-BA.

180. O patrimônio artístico da Bahia foi tema de entrevista de José Valladares para o jornal $A$ Tarde (Um problema em foco, em 22 de janeiro de 1959); ver Recortes de Jornais. Artigos de José Valladares II. 1945-1951. Biblioteca do MAB-BA.

181. Relatório da Inspetoria de Museus e Monumentos 1940, pasta s. n. Arquivo MAB-BA.

182. Correspondência José Valladares e Robert Smith, 9 jun. 1949; ver Dr. José Antonio do Prado Valladares. Correspondências Recebidas e Emitidas. Anos 1943-1958, pasta 04.Arquivo MAB-BA.

183. Relatório encaminhado ao Secretário de Educação e Saúde em resposta ao ofício no. 432 , relativo ao período de 1938 até junho de 1939 , 7 jul. 1939; ver Inspetoria, pasta s. n.Arquivo MAB-BA.

\section{Ibidem}

185. Para ir ao Rio Janeiro, obteve afastamento aprovado por decreto. Cf. Relatório ao Secretário de Educação e Saúde, 7 de julho 1939; ver Oficios Expedidos 19401959. José Antonio do Prado Valladares, pasta s.n.Arquivo MAB-BA

186. Godofredo Rebelo de Figueiredo Filho foi poeta modernista baiano; incorporou projetos de modernização social e cultural da Revolução de 30; dirigiu o 2. Distrito do Sphan-Dphan-Iphan de 1936 a 1974; cf. Marta Maria da Silva Brasil (2006, p. 28-

\section{Elaboração de normas}

Em missivas enviadas a Rodrigo M. F. de Andrade, José Valladares compartilhou suas dúvidas em relação ao conteúdo do regulamento. Aí fica explicita a intervenção dos meandros políticos no destino do Museu. A mudança de endereço do Campo Grande (Solar Pacífico Pereira) para o bairro de Nazaré (Solar Góes Calmon), por conta da compra da coleção e da casa Góes Calmon, foi uma situação difícil de contornar e causou efeitos profundos. Paralelamente a essa contingência, as tarefas internas - documentação das coleções; criação de um novo tratamento expositivo, muito dirigido pelas características de artes decorativas da Coleção; divulgação, em forma de programação cultural - podem ser consideradas atividades bem sucedidas que, se não chegaram a cumprir as expectativas do diretor, deixaram sua marca positiva na vida cultural baiana.

Do primeiro relatório (1939), entende-se que a instituição encontrada por José Valladares estava aquém das funções que ele poderia cumprir. Em sua opinião, havia potencial para o Museu tornar-se um "órgão vivo de educação popular, um centro de estudos históricos e etnográficos, onde se terá à mão uma documentação abundante sobre a história social da Bahia" 183 e, para que fossem cumpridas essas finalidades, precisava do apoio efetivo da Secretaria de Educação e Saúde, o órgão superior ${ }^{184}$. Seu programa de ação era amplo e cheio de alterações: era preciso mudar o horário de atendimento, fazendo abrir - Museu aos sábados e domingos (para aumentar o número de visitantes), cuidar da catalogação do acervo, "arrumar" as salas e galerias de exposição, criar atividades culturais complementares, instituir e manter uma linha de publicações, investir na propaganda, aumentar o quadro de funcionários e obter verbas para compra de material, livros e peças para o acervo.

Essa visão dos trabalhos de museu, anterior ao estágio nos Estados Unidos, evidencia que ele tinha conhecimentos para fazê-lo funcionar. Ao que tudo indica, esses conhecimentos foram obtidos no Rio de Janeiro, onde foi "estudar a organização dos serviços sob sua superintendência"185. $\bigcirc$ fato de ir para a capital do país - embora a documentação consultada não indique quem o incentivou ou convidou nem qual a instituição ou instituiçães visitadas - pode ser lido como atestado de sua proximidade com o "grupo do parrimônio", interligado através de amigos, como afirmou Antonio Cândido, formando a rede de contatos e de influências que, no Nordeste, tinha duas figuras proeminentes: Gilberto Freyre, respondendo pela 4. Região do Sphan, no Recife; e Godofredo Filho, dirigente da 5. regional, abrangendo Bahia e Sergipe ${ }^{186}$. Ambos se articulavam com Rodrigo.

Ter reunido (por decreto, em 1938), numa só repartição - a Inspetoria de Museu e Monumentos -, a Pinacoteca, o Museu e a Inspetoria Estadual dos Monumentos Nacionais, passando-os para a Secretaria de Educação e Saúde (em lugar da Secretaria do Interior e Justiça), requeria nova regulamentação. $\bigcirc$ quadro administrativo era novo, e os regimentos estavam defasados. A nova Inspetoria encontrava-se sob instruções datadas de 1927 (regendo a antiga 
repartição), e o Museu seguia instruções provisórias de 1931. Na relação entre a Inspetoria e o Museu, a implantação de novas regras poderia estipular normas para dar fluxo aos objetos recebidos via a recém-criada Inspetoria, que precisava ficar alinhada às diretrizes federais do Sphan: momento oportuno e interessante do ponto de vista político. José Valladares recorreu a Rodrigo para pedir colaboração nessa empreitada. Ir ao Sphan significava consultar os "estudiosos de nossa história e tradições, escritores, diretores de serviços públicos" 187 e obter a orientação dos que dirigiam os principais museus do país, argumentos que usou perante os superiores. Mas havia um problema: era preciso resolver questões locais no que competia à proteção do patrimônio histórico e artístico baiano. Não há referências sobre as instituições ou pessoas a quem teria recorrido, mas foi a Rodrigo que entregou o anteprojeto do novo regimento do Museu, quando este passou por Salvador, em agosto de 1939, para que opinasse sobre os dispositivos da legislação estadual de proteção aos monumentos históricos e artísticos, já que no Decreto-lei federal n. 25 (30 nov. 1937) havia indicações estabelecendo a criação de acordos entre a União e os estados para melhor coordenação e desenvolvimento da proteção ao patrimônio, ajustando a legislação estadual à federal.

Na correspondência entre José Valladares e Rodrigo, o tema "regulamento" perdurou por um tempo. $\bigcirc$ assunto era tenso, um "caso" a ser enfrentado ${ }^{188}$; mais parecia um quebra-cabeça de difícil resolução. Devido a entendimentos locais, não era fácil chegar ao consenso, deixando Valladares imprensado entre a intenção de trabalhar de acordo com os "pontos de vista do Serviço do Patrimônio" e as opiniões, ou determinações, da administração estadual baiana. A questão foi sendo empurrada, num ir e vir constante por caminhos oficiais e oficiosos. Para que o regulamento fosse aprovado, seria preciso antes definir a reforma geral da Secretaria de Educação, e a Inspetoria estava subordinada a ela. A certa altura, José Valladares foi consultado para dar sua opinião sobre as seções que comporiam a Inspetoria, e indicou três: a Administrativa, a Técnica e a de Extensão Cultural. A sugestão foi incluída no quadro geral da Secretaria, sem que fosse estipulado o que competia a cada uma delas; e o quadro não ficou "preenchido"189. A mesma proposta, porém mais completa, foi apresentada e discutida antes com Rodrigo, que a considerou "acertada", acrescentando algumas sugestões. A seção Técnica, que correspondia ao Museu, gerou toda uma discussão em torno da denominação das subdivisões no interior do organograma específico da Inspetoria: elas deveriam ser chamadas de "museus" (de história, de arte etc.) ou de "exposições" (de história, de arte etc.)? Rodrigo recomendou o uso de "exposições" já que a palavra "museu" compreendia a instituição no seu todo e não somente a exposição de peças ${ }^{190}$. Não se tratava, porém, somente de denominações, havia outro fator a considerar: José Valladares precisava da compreensão e da aceitação de seus superiores, como se lê em sua resposta a Rodrigo:

No que se refere à questão das denominações, sua sugestão para se dizer Arqueologia e Etnografia, em vês de Ciência, tem toda a razão de ser. Dizer porém, exposição de historia,
29). Bahia e Sergipe formavam a quinta seção do Sphan; cf. Rodrigo M. F. de Andrade (1987, p. 31).

187. Ibidem.

188. José Valladares para Rodrigo M. F. de Andrade, 4 dez. 1944.Ver Correspondências Recebidas e Expedidas, 1944-1958, pasta s. n.. Arquivo MAB-BA.

189. José Valladares para Rodrigo M. F. de Andrade, 19 nov. 1944.Ver Correspondências Recebidas e Expedidas, 1944-1958, pasta s.n.Arquivo MAB-BA

190. Rodrigo M.F.deAndrade para José Valladares, $18 \mathrm{dez}$. 1944. Ver Correspondências Recebidas e Expedidas 1944-1958, pasta s.n.Arquivo MAB-BA 
191. José Valladares para Rodrigo Melo F. de Andrade, 5 jan.1945.Ver Correspondências Recebidas e Expedidas, 1944-1958, pasta s.n.Arquivo MAB-BA; grifado no original.

192. Ibidem.

193. Ibidem.

194. José Valladares para Rodrigo Melo F. de Andrade, 19 nov. 1944.Ver Correspondências Recebidas e Expedidas, 1944-1958, pasta s.n.Arquivo MAB-BA

195. José Valladares para Rodrigo Melo F. de Andrade, 5 jan. 1945.Ver Correspondências Recebidas e Expedidas, 1944-1958, pasta s.n.Arquivo MAB-BA

196. José Valladares para Rodrigo Melo F. de Andrade, 19 nov. 1944; e Telegrama, 16 nov. 1944.Ver Correspondências Recebidas e Expedidas, 1944-1958, pasta s.n.Arquivo MAB-BA

197. Gabriel Bechara Filho (2007, p. 167), referindo-se a um artigo de José Valladares (1940), comenta que a reforma do Solar Pacífico Pereira fazia parte da política de Vargas para modernizar as instituições culturais herdadas da Velha República.

198. Ver tópico Edifício, em Relatório de 7 de julho de 1939. Ver Gestão 1939-1959, pasta s. n.Arquivo MAB-BA exposição de arte, etc., em vez de Museu de Historia, Museu de Arte, etc., - não creio que receba acolhida favorável da parte de meus superiores hierárquicos. Todavia, a fim de evitar a palavra Museu, vou sugerir Galeria, forma que se me afigura conciliatória ${ }^{191}$.

Se a sugestão conciliatória daria conta de prováveis incompreensões por parte das instâncias administrativas, no entanto, não era o principal: para ambos, a questão das divisões das seções não se limitava a um problema administrativo e, sim, ao devido enquadramento das coleções em campos específicos do conhecimento (arqueologia, etnografia), caracterizando o Museu. Na correspondência, tal discussão não teve continuidade, sendo suplantada por questões mais urgentes e operacionais, envolvendo outros aspectos. José Valladares tinha muito claro para si - levando a Rodrigo suas preocupações - que as interferências políticas poderiam dificultar o desenrolar cotidiano do Museu, por isso a ideia, a constar do regulamento, de um Conselho Consultivo. A intervenção política, questão séria discutida entre eles, teria (nas atribuições desse conselho) um mecanismo para frear o capricho de governantes "hoje muito bem intencionados, mas, amanhã, possivelmente menos esclarecidos e bem capazes de realizar compras, determinar publicações e promover comemorações, que somente far[iam] custar dinheiro e diminuir o renome que o Museu possa vir a ter $^{\prime \prime} 192$. Era preciso pensar no número de conselheiros, e, se alguns deles fossem colecionadores, talvez pudessem beneficiar o Museu em algum momento ${ }^{193}$. As preocupações de José Valladares com a intervenção de políticos e da política o fizeram pensar na possibilidade de vincular o Museu diretamente ao interventor ${ }^{194}$.

Fato é que as sugestões - pedidas a Rodrigo, e respondidas por ele, com o cuidado de não interferir no processo -, nem sempre iam adiante a ponto de chegar ao estrato oficial. Uma etapa a ultrapassar era a necessária consulta a personalidades do quadro administrativo local, que podiam (ou não) corroborar as formulações de José Valladares, preocupado em incluir as sugestões recebidas de Rodrigo. Nem tudo poderia ser acompanhado conforme os padrões federais; era preciso considerar as "dificuldades provincianas"195. Rodrigo era a figura de autoridade e interlocutor respeitadíssimo por suas opiniões - aspectos que saltam aos olhos dos leitores da correspondência - e também pelo apoio, muitas vezes direto, ao intervir em relação aos problemas do Museu, quando da passagem de políticos baianos pelo Rio de Janeiro ${ }^{196}$.

\section{Edifício-sede}

Enquanto corria o debate sobre o regulamento, que se estendeu anos a fio, acontecia, em 1945, a mudança do Museu para o Solar, Palacete ou Casa Góes Calmon. A acomodação do Museu, que desde os tempos do Arquivo já era ruim, não se encontrava bem no Solar Pacífico Pereira, mesmo com reparos em andamento 197 , o que possibilitaria a transferência da parte administrativa, da biblioteca e do laboratório de restauração para a "casa que the fica anexa"198 - informação indicativa da divisão de serviços dentro do próprio Museu, agora formado por uma estrutura mais complexa. Mas os reparos foram suspensos pelo 
uso do primeiro andar pela família de um contínuo do palácio do governo que, como vimos, havia sido determinado pelo gabinete do interventor. Além dessa ocupação indevida, o andar térreo, onde se encontrava a exposição permanente, foi cedido por ordem do interventor ao Departamento Estadual de Estatística, o que inviabilizou a visitação. Mais um fator empurrava a mudança: o prédio do Campo Grande, pertencente à Prefeitura, iria ser derrubado para dar lugar ao Teatro Municipal199.

Com a compra da Casa Góes Calmon, parecia que o estado resolveria o problema de instalação do Museu (e Pinacoteca), todavia não foi o que aconteceu, e essa transação foi outro tema nas cartas com Rodrigo. Para José Valladares, o governo da Bahia mostrava-se empenhado em dotar a cidade do Salvador de uma "instituição condigna"200. Rodrigo não foi tão otimista, vendo a mudança com "pesar", considerando a casa imprópria para a instalação do Museu e, desde o princípio, demonstrou a esperança de que fosse em caráter temporário ${ }^{201}$. Ambos criticaram a compra da casa, mas não da coleção. Rodrigo assim se expressou a respeito da Casa:

Você tem razão de receiar que os visitantes sejam induzidos em lamentável equívoco diante das simulações de colonial que o palacete abriga. Por isso mesmo desaconselhei muito a compra do imóvel juntamente com a coleção. Uma vez, porém, que se fez a aquisição e que houve a necessidade de transferir para ali o estabelecimento, você terá de suportar os inconvenientes aludidos, pelo menos durante algum tempo. Convirá, entretanto, insistir sempre pela mudança do museu para prédio mais adequado; si não para a velha fortaleza alvitrada pelo Interventor, para qualquer outra casa adequada e sem o defeito grave da nova séde 202 .

$\bigcirc$ prédio era "difícil", um "caso clínico muito sério", com "defeitos graves" 203 , eclético, cheio de compartimentos que dificultavam as exposições, e cheio de sobreposições de estilos, criando verdadeiros problemas que poderiam confundir os visitantes. Esse fato levou o diretor a escrever, no Guia do Visitante, uma introdução que explicava tal composição204. As condições eram tão inapropriadas, que José Valladares e Rodrigo aventaram a possibilidade de outro endereço, antes mesmo que a transferência para o Solar, no bairro de Nazaré, se concretizasse; e os dois exploraram algumas possibilidades junto a políticos: uma delas foi o Forte de São Pedro, visto com bons olhos por Rodrigo, que pôs - Sphan à disposição para elaborar um estudo, desde que fossem enviadas as plantas e a documentação fotográfica do local. $\bigcirc$ uso do Forte, um imóvel federal ficava, no entanto, na dependência de negociações diretas entre o interventor da Bahia e o presidente Vargas. $\bigcirc$ Forte foi uma possibilidade que acabou não vingando. Durante certa fase, José Valladares chegou a ficar esperançoso: a mudança para o Forte era um plano bom, mesmo havendo o receio da interferência política ${ }^{205}$. Em 1946, nova promessa, desta vez pelo governador Otávio Mangabeira, agora em torno do Paço do Saldanha (Liceu de Artes e Ofícios) e recebida com entusiasmo por José Valladares e Rodrigo ${ }^{206}$. Mais uma vez resultou em nada.
199. Cf. Relatório sobre as atividades da Inspetoria de Museus e Monumentos, entre agosto de 1943 a setembro de 1945, e Relatório do Movimento da Inspetoria de Museus e Monumentos, de 14 de outubro a 31 de dez. de 1944. Ver Gestão 1939-1959, pasta s. n.Arquivo MAB-BA.

200. José Valladares para Robert Smith, 15 out. 1944. Dr. José Antonio do Prado Valladares. Correspondências Recebidas e Emitidas. Anos 1943-1958, pasta 04Arquivo MAB-BA

201. José Valladares para Rodrigo Melo F. de Andrade, 14 mar. 1945. Correspondências Recebidas e Expedidas, 1944-1958, pasta s.n.Arquivo MAB-BA.

202. Rodrigo Melo F. de Andrade para José Valladares, 26 jun. 1945. Correspondências Recebidas e Expedidas, 1944-1958, pasta s. n.Arquivo MAB-BA.

203. José Valladares para Rodrigo Melo F. de Andrade - 19 e 26 de junho, 1945 Correspondências Recebidas e Expedidas, 1944-1958, Arquivo MAB-BA

204. Em uma Nota, José Valladares ([1946?b]) explica que, seguindo o exemplo dos museus, preocupados com a aprendizagem, exibia somente parte do acervo, $\mathrm{e}$ as informações constantes diziam respeito, em sua grande maioria, à Coleção Góes Calmon.

205. José Valladares para Rodrigo Melo F. de Andrade, 4 dez.; 18 dez.; 7 mar. 1944; 1. fev.; e 7 mar. 1945. Correspondências Recebidas e Expedidas. José A. P. Valladares-Rodrigo M. F. de Andrade. 1944 a 1958, pasta s.n.Arquivo MAB-BA.

206. José Valladares para Rodrigo Melo F. de Andrade, 19 ago. 1946. Correspondências Recebidas e Expedidas. José A. P. Valladares-Rodrigo M. F. 
de Andrade. 1944 a 1958, pasta s. n. Arquivo MAB-BA Em novembro do mesmo ano, José Valladares comunica que havia escrito para Otávio Mangabeira pedindo intervenção direta junto ao Interventor Cândido Caldas para a desapropriação do Paço (18 nov. 1946). Correspondências Recebidas e Expedidas José A. P. Valladares-Rodrigo M.F.deAndrade. 1944 a 1958 pasta s. n.Arquivo MAB-BA.

207. O custo do que era possível antever incluia 130 viagens de caminhão; 120 com 4 carregadores; 30 caixões vazios; 10 balaios; 5 quilos de corda de $1 / 2$ polegada; 2 quilos de corda fina; 3 de arame n. 18; sete quilos de pregos diversos; 2 martelos; 1 serrote $27 ; 1$ alicate "izolado"; 1 talhadeira 9 pelo preço de Cr\$20.115,00; Carta assinada pelo Zelador e Porteiro, encaminhada ao Diretor José Valladares, 20 abr. 1945. Arquivo MAB-BA

208. Relação dos objetos de maior volume, da coleção do Museu para calculo das despesas com a mudança para a Casa Góes Calmon (1943) Arquivo MAB-BA.

209. Ibidem.

210. Relatório sobre as atividades da Inspetoria de Museus e Monumentos, entre Agosto de 1943 e Setembro de 1945 .

211. José Valladares para Rodrigo Melo F. de Andrade, 7 mar.; 13 set. 1945 . Arquivo MAB-BA

212. O especialista chamado foi Pedro A. José Ghislandi; ver Relatório de Vistoria do Prédio à Avenida Angélica, $\mathrm{n}$. 198, Salvador, 21 fev. 1951 Arquivo MAB-BA.

213. A Tarde, 27 out. 1952 Recortes de Jornais. Biblioteca MAB-BA.

214. A Tarde, 14 nov. 1952 Recortes de Jornais. Biblioteca MAB-BA.
A transferência das coleções para a Casa Góes Calmon, definida em 1943, requeria cuidados especiais. O transporte das obras exigia responsabilidade, não era uma "carga" qualquer, não poderia ser levada "completa e à vontade, como se fosse[m] pacotes de papeis e livros sem importância". Seriam necessárias várias viagens de caminhão, e o custo era alto 207. Na Relação dos objetos de maior volume, da coleção do Museu para calculo das despesas com a mudança para a Casa Góes Calmon 208, com uma longa lista de itens, antes de apresentar o Resumo do cálculo, uma frase explica a dificuldade de se apresentar um orçamento completo em razão da dispersão do acervo: "Ainda existe o triplo que não foi possível relacionar, devido à arrumação com a ocupação do prédio por outra Repartição"209.

Para que a mudança acontecesse, seria preciso limpar o espaço e executar pequenas reformas na Casa, solicitadas em 1944. Quando José Valladares acabou a medição dos cômodos para as obras de limpeza liniciadas no mês seguinte), corria o mês de março de 1945. O que a princípio estava previsto para dois meses só se completou em setembro, quando foram transferidas as coleções e a biblioteca ${ }^{210}$. No dia 13 de setembro, José Valladares se disse "atrapalhado" e já percebia as dificuldades "irremediáveis" do novo endereç̧211.

Se desde o início a Casa Góes Calmon já não era apropriada, no decorrer do tempo iria apresentar problemas ainda mais sérios, a ponto de, em 1951, ter sido solicitada a visita de um especialista em restauração de edifícios históricos para dar seu parecer. Ele diagnosticou "lesões", fraturas nas paredes, cupins no travessão principal do telhado, problemas no escoamento das águas pluviais, nos esgotos, fuga de terras afetando as fundações deixando o terreno úmido, e a inadequação da instalação elétrica. A situação era de perigo e colocava em risco as coleções; era urgente um programa de reparos, que foi só parcialmente concretizado utilizando o próprio orçamento do Museu, sem que esse cobrisse o total das despesas ${ }^{212}$

As condições cada vez mais precárias da "Casa do Passado" foram denunciadas em reportagens no ano de 1952, com ênfase no valor das coleç̃eses para a Bahia. No jornal A Tarde, a manchete noticiou um fato "triste": o edifício Museu do Estado estava para desabar, e as coleções, equiparadas às melhores dos museus no país, estavam ameaçadas. Eram quadros, porcelanas, joias, objetos antigos e preciosos que ofereciam aos visitantes "um conjunto de trabalhos verdadeiramente artísticos, reveladores do bom gosto do povo baiano"213. Outra reportagem, quase um mês depois - com o extenso título de Fendas ameaçadoras põem em perigo a segurança do prédio. O edifício do Museu do Estado, onde se guardam tantas relíquias valiosas, está precisando de urgente conserto apresenta-o como monumento público baiano, um atestado da grandeza da Bahia em séculos passados, onde estavam guardados tesouros de valor histórico e material como "objetos de templos católicos" e de famílias "economicamente poderosas de condes e viscondes e da aristocracia rural de nossa terra"214.

Devido às condições sabidamente precárias do prédio, o tema de sua impropriedade voltou à baila em 1956. Desta vez, além de reforçar que as 
instalações não eram apropriadas, o argumento maior foi o de que não havia como escapar da necessidade de ampliação, a fim de poder o Museu ir além do que já era. $\bigcirc$ aumento do espaço significava apresentar peças que estavam guardadas, acomodar a biblioteca especializada, o arquivo, os serviços administrativos e técnicos, criar a galeria para exposições temporárias ou para terceiros que precisavam "do patrocínio do estabelecimento". José Valladares foi taxativo, declarando que, sem ampliação,

qualquer Museu se vê reduzido a uma função estática, sem que possa desenvolver um programa dinâmico, capaz de atrair a atenção do público. Fica na condição de simples repositório de peças de maior ou menor valor, mais ou menos bem arrumadas, que se visita uma vez na vida e não há razão para novidade para se voltar outra vez $z^{215}$.

As condições da edificação - de conservação, de iluminação desfavorável para as obras de arte especialmente as de pintura, a deteriorização da estrutura por conta dos "pequenos roedores", os efeitos do tempo sobre um material de qualidade inferior - não deixavam qualquer ilusão: "o edifício que [...] era chamado de palacete, entrou numa decadência física difícil de sustar"216. Mesmo que ocorressem obras, o problema da instalação do Museu permaneceria irresolvido ${ }^{217}$. Para a instituição não se atrofiar, a expansão era premente, e a questão era estudar se essa ampliação deveria acontecer na própria Casa ou se o estado deveria conseguir outra edificação, fazendo o Museu retornar ao centro da cidade, onde a "afluência de visitantes seja naturalmente maior, não sendo assim preciso fazer uma viagem especial a um bairro residencial"218.

Nos anos subsequentes, o problema continuou a agravar-se. Em 1956, as obras solicitadas à Secretaria de Viação e Obras Públicas - conservação, limpeza do edifício e galerias - não podiam ser realizadas, por dependerem da atualização do orçamento anterior, realizado pelo especialista. Em 1957, o governo continha as despesas e nenhuma obra podia ser realizada. De um ano a outro, os problemas existentes na Casa Góes Calmon eram literalmente transcritos do relatório. $\bigcirc$ Museu mal conseguia continuar as atividades de rotina, e os próprios funcionários foram chamados a trabalhar realizando reparos mais urgentes no telhado e refazendo a caiação externa: para melhorar a aparência que "recomendava mal um serviço público"219. Mais um ano se passou, e, em 1958, os problemas chegavam mais agravados 220 levando à transferência das coleções, após a morte de José Valladares ${ }^{221}$.

\section{Atividades de documentação do acervo}

Ainda no Solar Pacífico Pereira, amparado por um programa cujo objetivo de elevar o conceito do Museu perante a sociedade, José Valladares investiu simultaneamente em várias frentes de trabalho. Uma delas foi a classificação das coleções para deixar as peças "lado a lado", organizando-as de tal forma que não ficassem desconectadas entre si, e separando objetos em dois grupos: os "objetos de exposição" e "objetos de documentação"222. A
215. Inspetoria de Museus e Monumentos. Relatório relativo ao ano de 1956.13 ago. 1956. Gestão 1939-1959, pasta s. n.Arquivo MAB-BA

216. Ibidem

217. Ibidem. Foi enviado engenheiro de obras do Serviço de Obras da Secretaria, a quem o edifício foi mostrado em detalhes, que tomou notas para posterior orçamento. Com verbas do próprio orçamento do Museu, foram providenciados, nessa ocasião, reparos urgentes nos telhados e condutores de águas pluviais, e trancas nas portas e janelas.

218. Ibidem.

219. Cf. Inspetoria de Museus e Monumentos. Relatório relativo ao ano de 1957; ver tópico Instalações, Gestão 1939-1959, pasta s. n. Arquivo MAB-BA

220. Ver Inspetoria de Museus e Monumentos, Dados relativos ao ano de 1958 . Gestão 1939-1959, pasta s.n. Arquivo MAB-BA.

221. A Casa Góes Calmon passou por reformas em 1970, na gestão de Carlos Eduardo da Rocha, momento em que, para sua exposição, as coleções foram para locais provisórios. Na década posterior, o Museu foi transferido para o Palácio da Vitória, na avenida Sete de Setembro, no trecho conhecido como Corredor da Vitória, onde está até hoje.As coleções foram separadas: a de arte contemporânea passou a integrar o Museu de Arte Moderna da Bahia; e outras, em comodato, foram para o Museu do Recôncavo Wanderley Pinho, criado em 1971; cf Sylvia Menezes de Athayde (1997, p. 11).

222. Cf. Relatório Inspetoria de Museus e Monumentos, 1940; tópico Classificação. Ver Gestão 1939-1959, pasta s. n. Arquivo MAB-BA. 
223. No tópico em que constam essas informações (Catalogação), José Valladares noticia o envio de relatório específico sobre os trabalhos realizados no Rio de Janeiro (de 15 de julho a 15 de agosto), como membro de comissão do governo e participante como Inspetor de Museus e Monumentos; cf. Relatório Inspetoria de Museus e Monumentos, de julho a dezembro de 1939 Ver Gestão 1939-1959, pasta s. n.Arquivo MAB-BA

224. Idem. Ver tópico Classificação.

225. Idem.Ver tópicos Classificação, e Catalogação.

226.A título de exemplo, em 1948 foram catalogados 642 objetos e 100 peças fotografadas; em 1949, 1091 objetos catalogados e 160 fotografados, especialmente na seção de cerâmica; cf. respectivamente os relatórios de 1948 e de 1949 do Museu do Estado. Ver Gestão 1939-1959, pasta s. n.Arquivo MAB-BA.

227. Em 1948, o acervo da biblioteca especializada era de 2.500 volumes, catalogados pelo sistema decimal, com fichas bibliográficas adquiridas à Biblioteca do Congresso, Washington; cf.. Museu do Estado. Dados relativos ao ano de 1948; tópico Biblioteca. Ver Gestão 1939-1959, pasta s. n.Arquivo MAB-BA.

228. Cf. Relatório sobre as atividades da Inspetoria de Museus e Monumentos, entre agosto de 1943 e setembro de 1945; ver tópicos Relatório 1943, H. Batista-Catalogação, e 1945. em Gestão 1939-1959, pasta s.n., Arquivo MAB-BA. Dentre os documentos no MAB há correspondências com a Divisão de Pinturas e Fotografias da Biblioteca do Congresso, o Departamento American Wing, do Metropolitan Museum of Art, o Brooklin Museum, National Gallery of Art comentando o envio de ima- catalogação das coleções foi outra ação logo iniciada, com vistas à publicação do catálogo que, na segunda metade de 1939, já estava esboçado223, apesar da dificuldade, apontada pelo diretor, de não contar com fichários, deixando-nos entrever que $o$ ato de catalogar não prescindia do registro em fichas e de seu acondicionamento num arquivo.

Nos primeiros relatórios, os termos "classificar" e "catalogar" surgem separadamente sendo que, pelo primeiro, compreende-se o "parentesco" dos objetos - um trabalho que, por natureza, era demorado, mas trazia consequências positivas para a exposição 224 . Para catalogação não há explicações, não sendo possível apreender se era algo mais aprofundado, exceto pela informação de que, para ser realizada, demandava a relação completa dos objetos que compunham o acervo, atividade a ser iniciada ${ }^{225}$. $\bigcirc$ trabalho de catalogação foi tarefa continuada, tanto que os relatórios trazem dados sobre a quantidade de peças processadas; e, por assim dizer, ele foi aprimorado pelo rigor científico e pelo registro fotográfico das peças 226 .

O apoio para apurar o trabalho de pesquisa e de catalogação encontrava suporte em dois recursos que se complementavam: a biblioteca especializada e um "fichário de estampas". A biblioteca mereceu, por parte de José Valladares, cuidados e investimentos em aquisições, em doações e também em permutas, ampliadas após a viagem de José ao exterior ${ }^{227}$, quando o Museu passou a ter suas próprias publicações. $\bigcirc$ "fichário de estampas" (também chamado "coleção iconográfica"), oferecido em grande parte por instituições norte-americanas, era formado por cartelas com imagens de mobiliário, pintura, gravura, tapeçarias, têxteis, cerâmica e escultura ${ }^{228}$.

\section{Exposições}

Para melhor se compreender as diretrizes que foram sendo escolhidas na ampliação do acervo, é preciso antes comentar as intervenções nas exposições ocorridas nos dois espaços, o do Solar Pacífico Pereira e o da Casa Góes Calmon. $\bigcirc$ empenho de José Valladares para melhorar a exposição do acervo começou ainda no endereço do Campo Grande, ou seja, no Solar Pacífico Pereira. A organização da exposição acompanhou a divisão das seções, distribuídas em histórica (8 salas), numismática (1 sala), etnográfica (6 salas), história natural (1 galeria e 4 salas) e arqueológica (3 salas)229. Mais tarde aparece nos relatórios uma seção de "artes plásticas". No entender do Inspetor, uma boa exposição deveria seguir classificação rigorosa, sendo assim, o estudo prévio dos objetos é que daria condições para organizá-los e ajustá-los nas diferentes seções.

Para impressionar os visitantes, as exposições deveriam ser bem cuidadas, daí a importância do "arranjamento artístico de seus mostruários" 230, para os quais era preciso encontrar o ponto de equilíbrio entre o lado artístico e o científico, a fim de provocar o interesse ${ }^{231}$. Uma boa exposição seria a melhor e a mais convincente propaganda do Museu, servindo para incentivar novas 
ofertas. Prova irrefutável da utilidade do Museu e resultado da propaganda foi a constatação, no segundo semestre de 1939, de duas doações por dia ${ }^{232}$.

No solar do Campo Grande, José Valladares deu continuidade à participação do Museu nos festejos do Dois de Julho, data que passou a coincidir com a de sua inauguração e a da Pinacoteca. A reordenação das salas de exposição e o preparo de material de divulgação (como cartões com imagens de objetos relativos à tradicional festa baiana, para serem distribuídos aos visitantes) surtiram efeito: em 1939, o Museu recebeu 1.176 visitantes que perceberam as modificações ${ }^{233}$. Seguindo a tradição, a exposição comemorativa da data cívica era inaugurada com a presença de autoridades militares e civis; o Museu, como instituição pública, deveria harmonizar-se com certos rituais cívicos e expressar solidariedade a outras instituições culturais baianas ${ }^{234}$.

Veio a mudança para o Solar Góes Calmon, um outro sobrado e outro espaço complexo para instalar as exposições. Não seriam mais as seções que iriam dirigir a concepção da exposição, mas a Coleção, adquirida pelas mãos do interventor federal general Renato Onofre Pinto Aleixo. A Coleção era o destaque maior e deveria ter as qualidades artísticas ressaltadas, considerando que havia terminado o tempo das seções por áreas de conhecimento, com as mais diferentes peças formando "amontoados desagradáveis à vista", que criavam confusão. $\bigcirc$ arranjo expositivo deveria, agora, impregnar os visitantes com sensações de "ordem, clareza e bom gosto"235, para facilitar o aprendizado. Como nem tudo poderia ser mostrado, havia margem para renovações periódicas.

No novo endereço, o circuito expositivo foi concebido de modo completamente diferente, aproveitando a disposição dos cômodos da antiga residência, e pontualmente explicado no já referido Guia do visitante: a Sala de Entrada, a de Jantar, o Fumoir, a Primeira Ante-Sala, o Quarto Antigo, o Hall, a Segunda Ante-Sala, o Quarto do Oratório, a Sala de Visita e de Música, a Escada, o Patamar, as Salas do Segundo Andar e de Pintura Religiosa. Pelas salas, apresentavam-se peças recolhidas ainda nos tempos de Borges de Barros, como o sino da Câmara Municipal, de 1615, e as da nova Coleção. Porcelanas chinesas, japonesas, alemãs, inglesas, francesas e portuguesas; louça das Índias; camafeus, broches e outras joias; peças de mobiliário do século XVIII; lustres; pinturas e estampas de autores de renome ou seguidores de escolas europeias do início do XIX; objetos de uso eclesiástico; imagens sacras cristãs; tapetes; um piano de cauda. Esses são alguns dos elementos, dispostos de forma a auxiliar o visitante a entendê-los em contexto, ambientados e associados. Acoplado à Coleção, um elemento importante (a informar publicamente) era a procedência das peças, seu antigo pertencimento: objetos de antigas famílias baianas, muitas com títulos nobiliárquicos, condição que se tornou fator para agregar valor histórico às características artísticas ${ }^{236}$.

Foram esses o luxo e a riqueza divulgados no artigo Bahia and its Museum, ilustrado com fotos de Voltaire Fraga ${ }^{237}$. Numa Bahia de "sociedade mestiça", reunindo conceitualmente portugueses, índios e africanos - na linha promulgada por G. Freyre e o Sphan -, o Museu surge como a "representação gens ou fotos para o Museu do Estado da Bahia.

229. Cf. Relatório Inspetoria de Museus e Monumentos, 1940; ver tópico Classificação. Ver Gestão 1939-1959, pasta s. n. Arquivo MAB-BA. Arquivo MAB-BA

230. Cf. Relatório de julho a dezembro de 1939; tópico Arrumação. Ver Gestão 1939-1959, pasta s.n.Arquivo MAB-BA

231. Ibidem

232. Cf. Oficio de 20 de janeiro de 1940, tópico Propaganda.Ver Gestão 1939-1959, pasta s. n.Arquivo MAB-BA

233. Cf. Relatório de julho a dezembro de 1939; tópico Classificação. Ver Gestão 1939-1959, pasta s.n.Arquivo MAB-BA

234. Cf. Relatório... ano de 1943; tópico Iniciativas culturais. Ver Gestão 1939-1959, pasta s. n. Arquivo MAB-BA. Nesse espírito foi inaugurado o retrato do "Chefe da Nação" na sala do Inspetor, em comemoração ao seu aniversário (19 de abril) prestigiado por autoridades e seus discursos. Em relação a outras instituições baianas, a homenagem ao historiador João da Silva Campos, do IGBH, com a inauguração de retrato e de sala em seu nome, contou com a presença de membros do Instituto baiano, da Ala das Letras e das Artes, e do Sphan. Nesse evento, Isaías Alves dispôs o custeio de publicações para o Museu, a começar pelo livro do historiador homenageado, publicado com o titulo Procissões tradicionais da Babia (1941).

235. Ver Nota, em José Valladares ([1946?b]).

236. José Valladares, no espaço do Hall, incorporou elementos decorativos da Casa, como o teto pintado pelo artista baiano Prisciliano Silva, as grades reconsti- 
tuídas por Góes Calmon, a porta de duas folhas com rosáceas entalhadas com uma bandeira ao gosto do século XIX, criando um "arranjo moderno"; ver José Valladares ([1946?b]).

237. Ver José Valladares (1948)

238. Idem, p. 449-458.

239. As verbas do Museu aumentaram de 1946 a 1949. Em 1946, o custo foi de Cr\$ 129.800,00; em 1947, de Cr\$ 201.860,00; em 1948, de Cr\$ 613.316,00; e em 1949 . de Cr\$ 982.310,00. Nesse último ano, o aumento foi tão significativo que foram adquiridos " 1 camionette, 1 armário de aço, 1 aspirador, 1 ventilador, 1 câmara fotográfica 'Speed Graphic' e um ampliador fotográfico". Ver tópicos Progresso obtido e Material de expediente, de exposição e de ensino; em Museu do Estado. Dados relativos ao ano de 1949. Arquivo MAB-BA. Em 1950 , houve redução para $\mathrm{Cr} \$$ 546.462,00, o que interferiu no andamento de publicações e na participação do Museu no Salão de Belas Artes; o Museu foi socorrido pela intervenção direta do Gabinete da Secretaria de Educação e Saúde; ver tópico Dificuldades financeiras; $\mathrm{em}$ Museu do Estado..., 1950.Ver Gestão 1939-1959, pasta s.n. Arquivo MAB-BA.

240. O destino das verbas, no que se refere aos equipamentos, aponta para o programa de atividades do Museu. Foram comprados " 5 mostruários, 6 fichários, 3 máquinas de escrever, 1 câmara fotográfica, 1 máquina de projeções para diapositivos $5 \times 5$ e 4.642 [...] para o ensino de História da Arte, todos adquiridos na América do Norte"; cf. tópicos Progresso obtido e Material de expediente, de exposição, e de ensino, em Museu do Estado..., 1948.Ver Gestão 1939-1959, pasta s.n. Arquivo MAB-BA. da riqueza do passado da cidade", onde o visitante poderia ver itens de "grande distinção". Nesse artigo, a coleção Góes Calmon foi referenciada como uma das mais completas no país, e seu antigo proprietário, como pioneiro na preservação da herança histórica e artística. As fotos das peças devem ter sido selecionadas com rigor, para transmitir as qualidades constitutivas dos materiais nobres: madeiras de lei, ouro, prata em trabalhos de preciosa artesania, referendando a procedência do passado de elite - tal o contexto para apresentar um bracelete de crioula, em ouro, e uma penca em prata, do século XIX. No final do artigo, mencionava-se uma "pequena coleção de peças etnográficas", sem outros comentários $^{238}$. $O$ discurso, assentado na preciosidade das peças, para apresentar a Coleção fora do país foi o mesmo empregado no guia que deveria acompanhar o visitante no bairro de Nazaré, onde o Museu estava então localizado.

Depois do período dessa montagem, nada há nos relatórios sobre mudanças que alterassem a proposta expositiva. A indicação da compra de novas vitrines ("mostruários"), como aconteceu nos relatórios de 1948 e 1949, sugere a preocupação com a atualização do mobiliário expositivo para, talvez, reorganizar a disposição de peças, ou mesmo como garantia de segurança, mas, isso, fica no terreno das suposições.

\section{Ação Cultural}

A verba destinada ao Museu em 1948, um ano considerado de "progresso", aumentou consideravelmente ${ }^{239}$, possibilitando o desenvolvimento das atividades de extensão cultural e investimentos na compra de peças para o acervo, de mobiliário para o expediente e para a exposição, e para a "investigação técnica" e o ensino ${ }^{240}$. No ano seguinte, comemorava-se o IV Centenário da cidade do Salvador, o que se traduz numa boa oportunidade para obter a atenção dos políticos. O Museu do Estado da Bahia não poderia deixar de contribuir para o evento, escreveu José Valladares para o Interventor Federal, ancorado no argumento de que se tratava de uma instituição dedicada "ao estudo de nosso passado com a finalidade de reinterpretáto para as gerações presentes e futuras"241, pleiteando, com isso, o Paço do Saldanha como casa "definitiva" para $\circ$ Museu242. Mesmo que o objetivo de uma nova mudança para outro edifício não fosse atingido, tal como gostaria, ele viu na preparação para as festividades um espaço aberto à arrumação interna ${ }^{243}$. No entanto, a participação mais importante do Museu nas festividades foi organizar o primeiro Salão Baiano de Belas Artes, que, aos olhos de José Valladares, colocava a Bahia entre os centros artísticos mais vivos do país ${ }^{244}$. Por sinal, organizar exposições temporárias fora do espaço do Museu foi a saída que ele encontrou para superar as dificuldades com o edifício, dinamizando as atividades e apoiando jovens artistas baianos dedicados à vertente da arte moderna. 


\section{Conservação}

Diferentemente dos entraves relativos às atividades expositivas circunscritas ao espaço disponível, os cuidados com a conservação e o restauro de peças do acervo puderam receber bastante atenção. Não são poucos os recibos comprovando encomendas de molduras para a galeria de pintura, a compra de suportes para o apoio de peças (como pentes e salvas de prata), assim como recibos de trabalhos de restauração de telas, de peças de mobiliário, porcelanas, pentes e leques, objetos de cerâmica, esculturas e mesmo de diapositivos que se prestavam como material para aulas. Muitos desses trabalhos eram feitos por encomenda ${ }^{245}$, ainda que o Museu contasse com profissionais especializados no quadro fixo de funcionários ${ }^{246}$, como a conservadora Letícia Fernanda Siqueira Trigueiros (com cursos na Sorbonne e Louvre), Herundina Ferreira Batista (diplomada em técnicas de museus pelo Museu Histórico Nacional no Rio de Janeiro) e Noêmia Godinho (formada pela Escola de Biblioteconomia da Bahia ${ }^{247}$. Certamente, a qualificação das funcionárias elevava o padrão dos serviços internos, dando suporte de excelência para cuidar do acervo (incluído o da biblioteca), compondo um quadro funcional que propiciava ao Museu condições de operar com apuro técnico alicerçado em conhecimentos específicos. A formação técnica especializada já era reconhecida, tanto que José Valladares era consultado por membros do governo para os assuntos relativos a museu; "uma grande coisa", escreveu, vendo nisso a prova de reconhecimento da "assistência técnica" 248 .

\section{Ampliação do acervo}

A ampliação do acervo é outro ponto a destacar. A questão é como, e em que direção, já que a Coleção Góes Calmon vinha a sobrepujar, de longe - ao menos pelas fontes consultadas -, qualquer referencia até mesmo à Coleção Abott, ou a outros tipos de objetos, caso dos etnográficos.

A entrada de peças se dava pelas formas tradicionais: compra e doação, no mais das vezes, e ocasionalmente transferências ("recolhimentos" realizados em outros órgãos públicos). Depois dessa Coleção, composta de 818 objetos, o critério geral para compras foi continuar a adquirir peças preferencialmente "de origem baiana ou historicamente ligadas ao nosso passado" 249. Ou seja, sedimentar ainda mais a procedência regional do acervo como marco de prestígio, continuando a escolher, se possível, peças de qualidade, incluindo as de ourivesaria baiana ${ }^{250}$. Afinal, a Bahia tinha, a respeitar, uma tradição "criadora de arte"251. O diretor havia se tornado um exímio conhecedor, que via nos objetos, como qualidades inseparáveis, a história e a estética, e tinha preparo e tino para perceber de imediato o valor de uma peça (no sentido histórico, estético e monetário), ainda que nem sempre pudesse determinar a finalidade de suas escolhas ${ }^{252}$.
241. Cópia anexada à carta enviada ao "Ilustre amigo Dr. Otávio Mangabeira”, no momento em que não havia dúvidas de que seria ele o governador do Estado, como escreveu José Valladares. $\mathrm{O}$ intuito era obter junto a Mangabeira apoio para conseguir a transferência do Museu para o Paço do Saldanha; cf. Memorial ao Exmo. Interventor Federal sobre a instalação definitiva do Museu do Estado como parte da contribuição do Governo do Estado nas comemorações do Quarto Centenário da cidade do Salvador, [1948 ou 1949]. Ver Gestão 1939-1959, pasta s.n. Arquivo MAB-BA.

242. Ibidem.

243. Outro aumento na verba deu condições para a compra de "4 mostruários de fabricação inglesa, com paredes e prateleiras de cristal", um deles posto na entrada para apresentar as últimas aquisições, com a expectativa de renovar a mostra que deveria acontecer duas vezes por ano. Ver Gestão 1939-1959, pasta s.n. Arquivo MAB-BA.

244. Ver tópicos Exposição-Material de Expediente, e Exposição. Museu do Estado..., 1949. Ver Gestão 19391959, pasta s. n. Arquivo MAB-BA.

245. A exemplo de recibos de 1940, 1941, 1947, 1949, 1957. Ver Gestão 1939-1959, pasta s. n. Arquivo MAB-BA. $O$ restaurador Edson Mota, perito do Sphan, prestou serviços de restauração para o Museu do Estado da Bahia; cf. Correspondência Rodrigo M. F. de Andrade para José Valladares, 4 fev. 1949. Correspondências Recebidas e Expedidas. José A. P. Valladares-Rodrigo M. F. de Andrade. 1944 a 1958, pasta s. n. Arquivo MAB-BA.

246. Em 1943, o quadro da Inspetoria de Museus e Monumentos contava com funcionários efetivos ( 1 inspetor, 
1 assistente, 1 auxiliar de 1 . classe, 1 conservador de 2 . classe, 1 porteiro de 1 . classe, 1 servente de 3 classe) e extranumerários (1 auxiliar técnico, 1 auxiliar de fiscalização, 1 datilógrafo, 1 servente de 1 . classe, 2 serventes de 3. classe). Isso consta dos estatutos que foram alterados pelo decreto 12.897 (13 nov. 1943); cf. Relatório... entre Agosto de 1943 e Setembro de 1945 . Ver Gestão 1939 1959, pasta s. n. Arquivo MAB-BA.

247. Cf. Museu do Estado. Dados relativos ao ano de 1948 . Ver Gestão 1939-1959, pasta s. n.Arquivo MAB-BA

248. José Valladares para Rodrigo M. F. de Andrade, 7 mar. 1945. Correspondências Recebidas e Expedidas. José A. P. Valladares-Rodrigo M. F. de Andrade. 1944 a 1958, pasta s. n. Arquivo MAB-BA.

249. Cf. Relatório...Agosto de 1943 e Setembro de 1945; tópico Entrada de objetos. Ver Gestão 1939-1959, pasta s.n. Arquivo MAB-BA.

250. Cf. Museu do Estado da Bahia. Dados relativos ao ano de 1949 e de 1948; tópico Aquisições. Ver Gestão 1939-1959, pasta s.n.Arquivo MAB-BA.

251.Ver Que nos trará 1949?, Diario de Noticias, 1 jan. 1949. Recortes de jornais. Biblioteca do MAB-BA.

252. O "descobrimento" de um crucifixo de jacarandá do século XVIII, "fora do comum", comunicado a Rodrigo (e com ótimo preço), foi informado ao interventor general Cândido Caldas. Este não quis correr o risco de adquiri-lo sem o respaldo de precedentes federais similares, mesmo que a verba estivesse consignada em orçamento. A excelência da peça contou com o apoio de Robert Smith e Elísio Lisboa; cf.José Valladares para Rodrigo M. F. de Andrade , 12 mar. 1947. Correspondências Re-
As "ofertas" eram outra via de ampliação do acervo do Museu. Os "ofertantes" enviavam os mais diversos tipos de objetos que, para o diretor, significavam estar o Museu repercutindo socialmente devido à boa propaganda. Tanto é que as primeiras ofertas, num total de 375 , chegaram pelas mãos de autoridades: o Secretário de Educação e Saúde, com uma coleção de documentos latas, cartas, atestados, álbum fotográfico com "relíquias históricas" da Bahia, uma chave de porta de um antigo prédio colonial); servidores públicos da Secretaria de Segurança Pública, com um "abundante material etnográfico"; e outros doadores com "peças de numismática" e "elementos de história"253.

As categorias "história" e "arte" parecem ter permanecido tão flexíveis que -para doações - podiam abarcar objetos tão diferentes como carimbos, mapas, impressos, retratos e vestuário, peças em cristal, medalhas, gravuras, cartões postais, clichê, distintivos, fotografias, uniforme da guarda nacional, documentos e retratos, cópias de gravura, desenhos. O próprio José Valladares doou " 2 quadros de formatura de médicos da faculdade de medicina da Bahia de 1920 e 1924", talvez - ou mais uma vez - preocupado com a mudança de costumes, que transformava os objetos, relatando essa tensão como cronista de artes plásticas ${ }^{254}$.

Em 1955, respondendo a uma solicitação do Conselho Internacional de Museus (lcom), José Valladares prestou a seguinte informação sobre o acervo (que, no conjunto, mantinha o ecletismo):

Presentemente, possui o Museu do Estado cerca de 9.500 objetos, compreendendo pinturas e desenhos, esculturas, gravuras e estampas, moedas e medalhas, cerâmica, peças de geologia e etnografia, indumentária, manuscritos e autógrafos, armas, mobiliário e alfaias, e peças outras que não se enquadram nas classificações acima. Dêste acervo destacam-se, pelo seu valor artístico ou histórico, as pinturas, as peças de louça e o mobiliário e as alfaias. Dada a falta de espaço tiveram estas preferências para a exposição, de sorte que, a julgar pelo material no momento à vista, deixa o Museu a impressão de apenas se ocupar de arte retrospectiva ${ }^{255}$.

Em 1950, com a redução no orçamento, as compras minguaram. Além disso, o mercado de antiguidades estava inflacionado, e o Museu não tinha como concorrer com os colecionadores particulares ${ }^{256}$. $\bigcirc$ maior número de entradas sendo por ofertas, dava o contrapeso para as poucas compras que puderam acontecer. A linha geral das compras, transferências e ofertas caminhava para a inclusão de peças afins ao conjunto geral do acervo, não só na vertente das artes decorativas mas também na categoria ampla de "históricos"257. Próximo ao final dessa década, entende-se, pelos relatórios, que estava aberta a passagem para a introdução de peças mais contemporâneas, como trabalhos de artistas plásticos baianos, de arte popular e de artesanato que, depois, iriam servir de núcleo inicial para o Museu de Arte Moderna, inaugurado em janeiro de 1960258.

Fato é que ao Museu chegavam peças recolhidas em terreiros de candomblé, mas ficavam ocultas - e silenciada sua representatividade social e cultural no espaço expositivo no Solar Góes Calmon -, ainda que, vale lembrar, 
no espaço anterior do Solar Pacífico Pereira houvesse material da seção etnográfica ${ }^{259}$. Mesmo na Bahia, a cultura afro-brasileira encontrava obstáculos a contornar ${ }^{260}$. Todavia, isso não significa ausência de interesse por parte do Inspetor, que, através das publicações do Museu ${ }^{261}$, manteve linha aberta para etnografia, arqueologia e manifestações populares; e, na condição de cronista, afirmou, por exemplo, o interesse e importância da arte popular para o panorama artístico do país, dando ênfase ao ponto de vista das artes plásticas 262 .

\section{Função educativa}

Para o Museu, responder pela função preponderante da educação foi meta definida, por sua importância cultural e cívica, na época de Isaias Alves na Secretaria de Educação e Saúde; e meta afinada às expectativas do Estado Novo na Interventoria de Landulpho Alves ${ }^{263}$. Mas, com o tempo, a ideia de programa educativo e de extensão cultural assumiu a forma de um composto de atividades registradas nos relatórios oficiais: exposições realizadas em outros espaços que não o do solar; as publicações do Museu, que poderiam servir para permutas com outras instituições; cursos e conferências loferecendo temas sobre arte ou história da arte no intuito de enriquecer seu ensino), ministrados por Letícia Trigueiros Danneman (funcionária do Museu), ou por personalidades que passaram pela Bahia, como Germain Bazin e Sergio Milliet; ou um curso livre de gravura (com duração de três meses) no estúdio de Mario Cravo, em 1950264.

Como material de divulgação, José Valladares pensou em informativos com reproduções de quadros ou objetos que fossem alusivos aos feriados nacionais, por sua importância histórica, fazendo valer o cumprimento da função cívica do Museu, numa justificativa usada para convencer as autoridades da necessidade de enveredar com maior aprofundamento na pesquisa do acervo ${ }^{265}$.

Pouco se lê sobre o atendimento a escolares; se estes participavam de visitas especiais, devem ter sido arroladas, nesses mesmos documentos, na parte referente à visitação, que decaiu com o endereço de Nazaré, no Solar Góes Calmon. $O$ índice de visitantes ali era "medíocre", levando em conta que o Museu ficava aberto à visitação pública nos fins de semana e que se contava com o serviço extraordinário dos funcionários ${ }^{266}$. Mesmo com a exposição e a programação propostas, recuperar a visitação que acontecia no Solar Pacífico Pereira - 15.839 visitantes/ano, em 1938 - levou tempo ${ }^{267}$. Ocorreram picos de visitação quando houve eventos na cidade do Salvador, por ocasião de congressos relativos às festas do centenário (1949), ou devido ao aumento da afluência de turistas. Pouco a pouco, escreveu José Valladares a Rodrigo, o Museu tornava-se um lugar de visita obrigatória ${ }^{268}$. Entretanto, ele alimentou o desejo de voltar para o centro da cidade, o que também não viu concretizar-se.

Há duas fases observáveis e bem diferentes entre si na dinâmica institucional do Museu do Estado da Bahia de 1938 a 1959. Na primeira, de cebidas e Expedidas. José A. P.Valladares-Rodrigo M. F. de Andrade. 1944 a 1958, pasta s. n.Arquivo MAB-BA.

253. Nem sempre as doações estão discriminadas nos relatórios, mas, no caso, constam os nomes de Altino Teixeira e Armênio Barbosa, da Secretaria de Segurança Pública; Francisco de Assis Bensabath (numismática); Engenheiro J. da Silva Campos (história); cf. Relatório, 1940; ver tópico Propaganda. Ver Gestão 1939-1959, pasta s. n.Arquivo MAB-BA

254. A transformação dizia respeito aos quadros de formatura, que antes ocupavam lugar de destaque nas casas de família e, por esses tempos, transformados em "maquete de monumento"; cf. José Valladares (1957, p. 99-101).

255. Cf. Informações para o Comitê Nacional ICOM, 13 maio 1955. Ver Gestão 1939-1959, pasta s. n. Arquivo MAB-BA.

256. Ibidem.

257. Ulpiano B. de Meneses (1998) explica que, em nossa sociedade, os atributos para objeto "histórico" são a peculiaridade, a singularidade e a aura (no sentido benjaminiano), associados à impossibilidade de qualquer substituição, respondendo por necessidades do presente cujo estatuto é de ordem ideológica e não funcional. O atributo "antigo" opera o valor privilegiando em particular as classes dominantes.

258. Cf. Sylvia Menezes de Athayde (1997, p. 11).

259. Para Anadelia Romo, a Bahia é um "museu vivo" (living museum). Considera José Valladares um valente defensor das tradições locais, ao expor objetos e indumentária das tradicionais baianas, com o apoio de Isaias Alves, então chefe da Secretaria de 
Educação e Saúde; a política do Estado Novo encorajou tal inclusão, mas não como elemento identitário local; ver Anadelia Romo (2009; 2010). De fato, na exposição José Valladares: o Mestre, realizada no MAB (junho, 2010), com curadoria de Sylvia Menezes de Athayde (diretora), há fotos em que se veem peças indígenas e afro-brasileiras (ou afro-baianas), expostas no Solar Pacífico Pereira, da mesma forma que grupos de escolares visitando o Museu.

260. Edson Carneiro, autor de "Candomblé na Bahia" (publicado pelo Museu do Estado da Bahia) temia o desprestígio pelo fato de ter discordado dos "historiadores oficiais" de Salvador. Ver Edson Carneiro para José Valladares, 22 nov. 1952.; ver Pasta Correspondência recebida, s.n. Arquivo MAB-BA. Em 1951 José Valladares informa a Carlos Galvão Krebs, folclorista gaúcho, que havia por volta de 121 terreiros de candomblé ou mais ; ver José Valladares para C.G.Krebs, 3 nov. 1951. Dr. José Antonio do Prado Valladares. Correspondências Recebidas e Emitidas.Anos 1944 a 1954, pasta 06. Arquivo MAB-BA.

261. Cerca de 15 títulos sobre assuntos culturais indígenas e afro-brasileiros foram publicados pelo Museu de 1941 a 1960.

262. Cf. Respectivamente: Interesse pela arte popular,crônica de 12 abr. 53, e em O mau gosto nas ruas da cidade, crônica de 16 maio 1954 e em José Valladares (1957, p.112).

263. Cf. Isaias Alves, 1939: 124.

264. Eventos que mereceram comentários: A lição Germain Bazin; A conferencia de Sergio Milliet;As gravuras de Poty; ver José Valladares (1951).

265. Ver Museu do Estado.
1938 a 1945, o Museu se encontrava em consolidação, instalado no Solar Pacífico Pereira. Ao assumi-lo, José Valladares tinha em mãos um acervo eclético (para representar a história) e a coleção Abott (para tratar da arte). Ele manteve, em parte, as práticas museológicas que encontrou, mas estava preparado com um projeto para mudar o rumo institucional, a ponto de tornar a instituição, de fato, um ponto de referência para a cultura baiana. Na segunda fase, de 1945 a 1959, a partir da mudança para o Solar Góes Calmon, a tônica de dinamização, como vimos, foi outra: mais apuro técnico, mais cuidado com a preservação dos objetos e com a proposta museográfica expositiva; atenção para com a biblioteca, como apoio da pesquisa; um programa de atividades culturais e de publicações dirigido para um público que se supõe interessado mas, provavelmente, restrito; escolhas determinadas, até certo ponto, para a ampliação do acervo, dando lugar a um deslocamento conceitual e das diretrizes expositivas. Convém relembrar que José Valladares conhecia bastante os museus no Brasi|269 e, numa crítica contundente, foi contrário a ideia de criação de um museu de arte na Bahia, clamando para que fosse dada maior atenção ao Museu do Estado, que já cumpria esse papel270.

\section{Quarenta anos do Museu do Estado da Bahia}

No horizonte da proposta de identificar os diferentes ideais de funcionamento na trajetória do Museu do Estado da Bahia de 1918 a 1959, entendemos que importa ressaltar alguns aspectos.

Antes de tudo, o atestado de que o primeiro museu estadual da Bahia esteve em atividade ao longo desse período, e tal atividade foi modificada sob determinados influxos e tendências culturais, que alteraram seu perfil e características. No decorrer desses quarenta anos, transformaram-se as perspectivas de patrimônio, de memória, história, cultura e educação e, no caso do Museu, foram sendo apropriadas e adequadas pelos gestores, ao implementarem suas ideias para fazê-lo funcionar, sem esquecer das contingências específicas do contexto baiano. A junção de coleções relevantes, as sucessivas mudanças de endereço até que ficasse alojado no Solar Góes Calmon ou, ainda, as leis e decretos que alteraram seu estatuto administrativo (por diferentes motivos, criando ou suprimindo seções, definindo denominações e junções) não foram os únicos fatos a tornar o percurso do Museu do Estado da Bahia representativo. É preciso considerar que museus constroem elos de associação com o poder, elos esses que interferem na construção das narrativas visuais a justificar o discurso apresentado e, por isso, "mostram" ideias e valores de forma particular ${ }^{271}$. Sendo assim, num determinado quadro sociocultural, os museus têm funções específicas a cumprir, uma vez que não estão isolados da estrutura social que thes dá sustentação.

O Museu do Estado da Bahia caminhou envolto em conflitos de natureza diversa, que o levaram a ter alterado seu modo de funcionamento. $\bigcirc$ 
deslocamento de um pequeno museu, gerado no Arquivo Público da Bahia, para transformar-se no museu oficial do Estado foi resultado de um processo de institucionalização e reconhecimento, em que se mesclaram as personalidades de gestores, suas expectativas pessoais (postas à prova diante da hierarquia administrativa), e uma série de relações locais e, mesmo nacionais, às quais a entidade respondeu. Tramas - pode-se dizer - que, como vimos, influíram na condução de seu destino. A trajetória do Museu não foi linear, e seu ideal de funcionamento não foi único: eis o ângulo pelo qual advogamos a importância de considerar o Museu do Estado da Bahia bem mais do que o ponto inaugural do Museu de Arte da Bahia.

Da Primeira República para o Estado Novo, muita coisa mudou. E mesmo depois. E as emanações dessas mudanças reverberaram na Bahia. A vida social e cultural na cidade de Salvador já vinha sendo modificada bem antes de 1918, pela introdução de elementos modernizadores, vinculados a um discurso civilizador $^{272}$. Uns tinham olhos para a defesa da herança colonial, outros para o progresso identificado ao moderno, sinalizando a tensão entre os opostos. $\bigcirc$ ímpeto de progresso e modernização continuou, décadas depois, quando a Bahia se viu motivada a participar do desenvolvimentismo mobilizado pela industrialização. E toda essa conjunção de aspectos políticos le mesmo econômicos) influiu também sobre o que era esperado e feito no Museu. Ao lado dessas influências, outra não menos significativa: os modelos de museu que serviram para modificar-Ihe o perfil. Na primeira e segunda fases (1918 a 1937), a inspiração declarada vinha dos museus brasileiros de história natural lo Paulista, - Goeldi e o Museu Nacional), mas a adaptação o fez mais próximo de um museu eclético, com seções que assim o representavam, mas sem a produção científica correspondente. Depois (1938-1959), o modelo seguido foi o dos museus norte-americanos que, como se sabe, dá ênfase bem maior à divulgação e à educação. As mudanças, então, vão se fazendo presentes especialmente no plano das práticas museológicas. Nesse percurso, o Museu passa de mostruário quase recluso a uma elaborada exposição, ambientada em um solar, conquistando assim mais presença e expressão social traduzidas em capital simbólico.

Oesperado "espírito dos antepassados", a intenção de preservar a história e de determinada memória social foi constante, mas alterada pelas intenções e intervenção de gestores que se tornaram porta-vozes de expectativas do Estado: ter um museu significava, como disse Borges de Barros, apresentar um adequado grau de cultura, garantir um índice de evolução e demonstrar o gosto refinado. E as coleções - Abott e Góes Calmon -, que acabaram por representálo, foram assumidas como signos da arte e da cultura baiana. Sem muita margem de engano, pode-se dizer que foi um serviço útil, mas, também, mais um elemento de distinção para a sociedade local no processo de modernização.
Dados relativos ao ano de 1948; cf. Gestão 1939-1959, pasta s.n.Arquivo MAB-BA

266. Cf. Museu do Estado. Dados relativos ao ano de 1949,1956 e 1958. Gestão 1939-1959, pasta s.n. Arquivo MAB-BA

267. Cf. Inspetoria de Museus e Monumentos. Movimento de Visitantes e Expediente 1938-1939; 7 jul. 1939. Gestão 1939-1959, pasta s.n.Arquivo MAB-BA,

268. Cf. Correspondência José Valladares para Rodrigo, 9 julho 1949. Em Correspondências Recebidas e Expedidas. José A. P. Valladares para Rodrigo M. F. de Andrade. 1944 a 1958, pasta s. n. Arquivo MAB-BA

269. Cf. José Valladares apresentou noticias sobre os museus no Brasil a exemplo de: Museus no Rio de Janeiro (publicada em A Tarde, 14 set. 1946); Dois museus de arte moderna (Diário de Noticias, 1948); Museus de São Paulo (Diário de Noticias, 22 ago. 1948); Museus, salões e coleções (Diário de Noticias, 11. 09.49); em Recortes de Jornais, artigos de José Valladares. Arquivo MAB-BA. E, ainda, Do Rio para a Bahia;A corte celeste de Abelardo Rodrigues; O Museu de arte popular de Pernambuco, ver, respectivamente, José Valladares (1957, p. 33-36; 55-57; 59-62).

270. Cf. Trata-se da crônica Museu de Arte; cf José Valladares (1957, p.83-85).

271. Cf. Durval Lara Filho (2006, p. 12, 15).

272. Ver Rinaldo C. N. Leite (1996); Raimundo N. da S. Fonseca (2002); Eduardo J. S. Borges (2003); Adroaldo de J. Beléns (2002); Jorge A. Uzêda (2006). 


\section{FONTES E REFERÊNCIAS}

\section{BIBLIOTECA DO MUSEU DE ARTE DA BAHIA}

Recortes de jornais, encadernados

A CASA da Bahia. A Tarde, Salvador, 27 out. 1952. Recortes de Jornais.

APOSENTADORIA do inspector da Pinacotheca. A Tarde, Salvador, 13 out.1937. Recortes de Jornais.

AS BIBLIOTECAS da Bahia. A Tarde, out. 1946. Recortes de Jornais.Artigos de J.Valladares, I. 19461951.

A TARDE, 27 out. 1952. Recortes de Jornais.

A TARDE, 14 nov. 1952. Recortes de Jornais.

FENDAS ameaçadoras põem em perigo a segurança do prédio. A Tarde, Salvador, 14 nov.1952. Recortes de Jornais.

IMPARCIAL, 14 nov. 1935. Recortes de Jornais.

QUE nos trará 1949? Diario de Noticias, 1 jan. 49. Recortes de Jornais.

SÉRIE Conhece tua cidade. A Tarde, 1958-1959. Recortes de Jornais.Artigos de José Valladares, II.

SÉRIE Bahia ameaçada. A Tarde, 1958-1959. Recortes de Jornais.Artigos de José Valladares, II.

UM PROBLEMA em foco. A Tarde, 22 jan. 1959. Recortes de Jornais.Artigos de J.Valladares. II.

Periódicos e outros

ACTO, 1. Secção. Annaes do Archivo Publico e do Museu do Estado da Babia, Salvador, v. 7, n. 10, p. I-IV, 1923.

A INSPECTORIA estadual dos monumentos nacionaes e a sua finalidade. Annaes do Archivo Publico e Inspectoria dos Monumentos, Salvador, n. 18, p. 555-581, 1931.

ANNAES do Archivo Publico, Salvador, v. 1, n. 2, 1917.

ANNAES do Archivo Publico, Salvador, v. 2, n. 3, 1918.

ANNAES do Archivo Publico e do Museu do Estado da Babia, Salvador, v. 3, n. 4-5, 1919.

ANNAES do Archivo Publico e Museu do Estado da Babia, Salvador, v. 12, n. 15, 1928.

ANNAES do Archivo Publico e Inspectoria dos Monumentos, Salvador, n. 18, 1931.

ANNAES do Archivo Publico da Babia, Salvador, v. 25, 1937.

ARAGÃO,Antonio Ferrão Moniz de. Mensagem apresentada à Assembleia Legislativa do Estado da Babia, Sessão Ordinária, 14. Legislatura pelo Dr.Antonio Ferrão Moniz de Aragão. Salvador: Imprensa Oficial do Estado, 1917.

Exposição apresentada pelo Dr. Antonio Ferrão Moniz de Aragão ao passar, a 29 de Março de 1920, o Governo da Babia ao seu successor o Exmo. Snr. Dr.José Joaquim Seabra, 
empossado nesse dia no cargo de Governador do Estado no quadriênio de 1920 a 1924. Salvador: Imprensa Oficial do Estado, 1920.

BARROS, Francisco Borges de. Relatorio. Anais do Arquivo Público, Salvador, v. 2, n. 3, p. 293-296, 1918.

Relatorio apresentado pelo director do Archivo Publico e do Museu do Estado, em 14 de janeiro de 1919. Annaes do Archivo Publico e Museu do Estado da Babia, Salvador, v. 3, n. 4-5, p. 295-299, 1919.

CALMON, Francisco Marques de Góes. Mensagem apresentada pelo Exm. Snr. Dr. Francisco Mar ques de Góes Calmon, Governador do Estado da Babia, à Assembleia Geral Legislativa por ocasião da abertura da 2. Reunião Ordinária da 18. Legislatura, em 7 de abril de 1926.

Mensagem apresentada pelo Exm. Snr. Dr. Francisco Marques de Góes Calmon, Governador do Estado da Babia à Assembleia Geral Legislativa por ocasião da abertura da 1. Reunião Ordinária da 19. Legislatura, em 7 de abril de 1927.

DECRETOS do anno de 1931 ( $N^{\circ}$ s 7.181 a 7.464). Secretaria do Interior e Justiça. Bahia : Imprensa Official do Estado, 1935

DIARIO Oficial do Estado da Babia, Salvador, v. 5, n. 187, p. 3861-3864, 27 jun. 1920.

FONTES, Fiel. Museu do Estado. Annaes do Archivo Publico, Salvador, v. 2, n. 3, p. 285-287, 1918.

LEI n. 2052, de 20 de março de 1928. Annaes do Archivo Publico e Museu do Estado da Babia, Salvador, v. 15, p. 3-4, 1928.

LEIS do Estado da Babia do anno de 1918. Salvador: Imprensa Oficial do Estado, 1921.

O DR.AFFONSO de E.Taunay no Instituto Geographico e Historico da Bahia. Revista do Instituto Geographico e Historico da Babia, Salvador, v. 54, p. 341-370, 1928.

RELATÓRIO apresentado ao Exmo. Snr. Dr. secretário do Interior e Justiça. Annaes do Archivo Publico da Bahia, Salvador, n. 25, 1937.

REVISTA do Instituto Geographico e Historico da Bahia, v. 53, 1927.

SEABRA, José Joaquim. Mensagem apresentada à Assembleia Legislativa do Estado da Babia em sua 1. Reunião da 16. Legislatura pelo Dr.José Joaquim Seabra, Governador do Estado. Salvador: Imprensa Oficial do Estado, 1922.

FONTES DO ARQUIVO DO MUSEU DE ARTE DA BAHIA (MAB-BA)

Gestão 1939-1959, pasta s. $n$.

INSPETORIA DE MUSEUS E MONUMENTOS. Dados relativos ao ano de 1958. Informações Relativas à Inspetoria de Museus e Monumentos, jul.-dez. 1939, 20 jan. 1940. . Movimento de visitantes e expediente 1938-1939, 7 jul. 1939. Quadro comparativo do movimento da Inspetoria de Museus e Monumentos, 1939, 1940 e 1941, 23 set. 1941. Relatório relativo ao ano de 1956 Relatório relativo ao ano de 1957 
Correspondências, relatórios e outros

CORRESPONDÊNCIAS [Loja Mattos para Gabriel Godinho], 30 jun. 1931.s. 1.

Correspondências expedidas, pasta s. $n$.

CORRESPONDÊNCIAS..., 28 out. 1937.

CORRESPONDÊNCIAS..., 12 nOv. 1937.

CORRESPONDÊNCIAS..., 22 dez. 1944.

Dr. F. Borges de Barros.Anos 1931 a 1934. Correspondências expedidas, pasta s. $n$.

CORRESPONDÊNCIAS, 15. jan. 1931.

CORRESPONDÊNCIAS, 3 mar. 1931.

CORRESPONDÊNCIAS, 16 maio 1931.

CORRESPONDÊNCIAS, 6 ago. 1931.

CORRESPONDÊNCIAS, 17 set. 1931.

CORRESPONDÊNCIAS, 1 mar. 1932.

CORRESPONDÊNCIAS, 5 maio 1932.

CORRESPONDÊNCIAS, 3 jun. 1932.

CORRESPONDÊNCIAS, 30 maio 1933.

CORRESPONDÊNCIAS, 19 set. 1933.

CORRESPONDÊNCIAS, 14 out. 1933.

CORRESPONDÊNCIAS, [s.d.] mar. 1934.

CORRESPONDÊNCIAS. 17 jul. 1934.

CORRESPONDÊNCIAS, 26 jul. 1934.

Dr.José Antonio do Prado Valladares. Correspondências Recebidas e Emitidas.Anos 1943-1958, pasta 04 .

Carta a Odorico Tavares, diretor do jornal Estado da Bahia, 26 jan. 1944.

Dr.José Antonio do Prado Valladares. Correspondências Recebidas e Emitidas.Anos 1944-1954, pasta 06.

Henry Alen Moe, Secretário Geral da Fundação NY, para José Valladares; 5 mar. 1948. 
Correspondências 1945-1949, pasta s. n.

VALLADARES, José. Relatório de viagem, 2 fev. 1945.

Gestão 1939-1959, pasta s.n.

Carta assinada pelo Zelador e Porteiro, encaminhada ao Diretor José Valladares, 20 de abril de 1945. (Arquivo MAB/BA).

Edson Carneiro para José Valladares, 22 nov. 1952.

Informações para o Comitê Nacional ICOM, 13 maio 1955.

José Valladares para Carlos Galvão Krebs, 3 nov. 1951.

José Valladares para Robert Smith, 9 jun. 1949.

José Valladares para Robert Smith, 15 out. 1944.

Relação dos objetos de maior volume, da coleção do Museu para calculo das despesas com a mudança para a Casa Góes Calmon, [193?].

Inspetoria de Museus e Monumentos. Relatório do movimento de 14 de outubro a 31 de dezembro de 1944.

Inspetoria de Museus e Monumentos. Relatório relativo ao ano de 1956, 13 ago. 56.

Inspetoria de Museus e Monumentos. Relatório relativo ao ano de 1957.

Inspetoria de Museus e Monumentos, Dados relativos ao ano de 1958.

Memorial ao Exmo. Interventor Federal sobre a instalação definitiva do Museu do Estado como parte da contribuição do Governo do Estado nas comemorações do Quarto Centenário da cidade do Salvador, [193?].

Museu do Estado. Dados relativos ao ano de 1948.

Museu do Estado. Relatório 1948.

Museu do Estado da Bahia. Dados relativos ao ano de 1949.

Museu do Estado da Bahia. Relatório 1949.

Museu do Estado da Bahia, Dados relativos ao ano de 1950.

Museu do Estado. Dados relativos ao ano de 1949, 1956 e 1958.

Oficio de 20 de janeiro de 1940.

Relatório, 1940.

Relatório de julho a dezembro de 1939.

Relatório de Vistoria do Prédio à Avenida Angélica, n. 198, Salvador, 21 fev. 1951.

Relatório encaminhado ao Secretário de Educação e Saúde em resposta ao ofício n. 432, relativo ao período de 1938 até junho de 1939, 7 jul. 1939.

Relatório para o Interventor Federal [então] Tenente Juracy Magalhães, 24 abr. 1931. 
Relatório sobre as Atividades Administrativas..., 7 jul. 1939 (por José Valladares).

Correspondências Recebidas e Expedidas.José A. P.Valladares-Rodrigo M. F. de Andrade. 1944 a 1958, pasta s. $n$.

José Valladares para Rodrigo M. F. de Andrade, 7 mar. 1944.

José Valladares para Rodrigo M. F. de Andrade, 4 dez. 1944.

José Valladares para Rodrigo M. F. de Andrade,Telegrama, 16 nov. 1944.

José Valladares para Rodrigo M. F. de Andrade, 19 nov. 1944.

José Valladares para Rodrigo M. F. de Andrade, 5 jan.1945.

José Valladares para Rodrigo M. F. de Andrade, 1 fev. 1945.

José Valladares para Rodrigo M. F. de Andrade, 7 mar. 1945.

José Valladares para Rodrigo M. F. de Andrade, 14 mar. 1945.

José Valladares para Rodrigo M. F. de Andrade, 19 jun. 1945.

José Valladares para Rodrigo M. F. de Andrade, 26 jun. 1945.

José Valladares para Rodrigo M. F. de Andrade, 13 set. 1945.

José Valladares para Rodrigo M. F. de Andrade, 4 dez. 1945.

José Valladares para Rodrigo M. F. de Andrade, 18 dez.1945.

José Valladares para Rodrigo Melo F. de Andrade [comunica que pediu a OtávioMangabeira para intervir junto a Cândido Caldas para a despropriação do Paço], 19 ago. 1946.

José Valladares para Rodrigo M. F. de Andrade, 12 mar. 1947.

José Valladares para Rodrigo M. F. de Andrade, 9 jul. 1949.

Rodrigo M. F. de Andrade para José Valladares, 18 dez. 1944.

Rodrigo M. F. de Andrade para José Valladares, 26 jun. 1945.

Rodrigo M. F. de Andrade para José Valladares, 18 out. 1946.

Rodrigo M. F. de Andrade para José Valladares, 4 fev. 1949.

\section{REFERÊNCIAS}

ABREU, Regina. Memória, história e coleção. Anais do Museu Histórico Nacional, Rio de Janeiro, v. 28, p. 37-64, 1996.

O Museu Histórico Nacional e a nostalgia de um império idealizado. In: HEIZER,Alda;VIDEIRA, Antônio Augusto Passos. Ciência, civilização e império nos trópicos. Rio de Janeiro:Access, 2001, p. 247-264.

ALBUQUERQUE, Wlamyra R. de. Algazarra nas ruas. Comemorações da Independência na Bahia (1889-1923). Campinas: Editora Unicamp; Centro de Pesquisa em Historia Social da Cultura, 1999. 
AGGIO,Alberto; BARBOSA,Agnaldo de Souza; COELHO, Hercídia Maria Facuri. Política e sociedade no Brasil (1930-1964). São Paulo:Annablume, 2002.

ALVES, Isaias. Educação e saúde na Babia na interventoria Landulpho Alves (abril 1938-junbo 1939). Salvador: Bahia Graphica, 1939.

ALVES, Marieta. Intelectuais e escritores baianos. Breves biografias. Salvador: Prefeitura Municipal de Salvador; Fundação Museu da Cidade; Funcisa, 1977.

AMADO, Jorge. Babia de Todos os Santos: guia de ruas e mistérios. 28. ed. Rio de Janeiro: Record, 1980.

ANDRADE, Rodrigo Melo Franco de. Rodrigo e o Shpan: coletânea de textos sobre o patrimônio cultural. Rio de Janeiro: MinC, 1987.

A ORDEM politica e a evolução artística (XVII). Cultura Política, Rio de Janeiro, v. 2, n. 17, p. 403404, jul. 1942.

ATHAYDE, Sylvia Menezes de (Org.). O Museu de Arte da Babia. São Paulo: Banco Safra, 1997.

BARATA, Mario. A importância e a técnica no museu contemporâneo. Cultura Política, Rio de Janeiro, v. 2, n. 17, p. 406-409, jul. 1942a.

Proteção ao nosso patrimônio histórico e artístico no quinquênio 1937-1942. Cultura Política, Rio de Janeiro, v. 2, n. 21, p. 327-354, nov. 1942b.

. Origens dos Museus Históricos e de Arte no Brasil. Revista do Instituto Histórico e Geográfico Brasileiro, Rio de Janeiro, v. 147, n. 350, p. 22-30, jan.-mar. 1986.

BARROS, Francisco Borges de. Da Amazonia ao Paraná. Diário de uma campanha cívica. Salvador: Imprensa Oficial do Estado, 1922.

Archeologia e bistória. Salvador: Imprensa Oficial do Estado, 1928.

A margem da bistoria da Babia. Salvador: Imprensa Oficial do Estado, 1934.

BECHARA FILHO, Gabriel. A construção do campo artístico na Babia e Paraíba (1930-1959). 2007. Tese (Doutorado em Ciências Sociais) - Programa de Pós-Graduação em Ciências Sociais, Faculdade de Filosofia e Ciências Humanas, Universidade Federal da Bahia, Salvador, 2007.

BELÉNS, Adroaldo de Jesus. A modernidade sem rostos: Salvador e a telefonia (1881-1924). 2002. Dissertação (Mestrado em História) - Programa de Pós-Graduação em História, Faculdade de Filosofia e Ciências Humanas, Universidade Federal da Bahia, Salvador, 2002.

BOAVENTURA, Edivaldo M. O Solar Góes Calmon. Salvador:Academia de Letras da Bahia, 2004.

BOCCANERA JuniorUNIOR, Silio. Babia Histórica. Reminiscências do passado. Registro do presente.Annotações (1549-1920). Salvador:Typographia Bahianna de Cincinnato Melchiades, 1921.

BOLAÑOS, Maria. La memória del mundo. Cien años de museología. 1900-2000. Gijón:Trea, 2002.

BORGES, Eduardo José Santos. "Modernidade negociada”, cinema, autonomia política e vanguarda cultural no contexto do desenvolvimentismo baiano (1956-1964). 2003. Dissertação (Mestrado em História) - Programa de Pós-Graduação em História, Faculdade de Filosofia e Ciên- 
cias Humanas, Universidade Federal da Bahia, Salvador, 2003. Disponível em: <http://www.ppgh. ufba.br/IMG/pdf/Modernidade_Negociada.pdf>

BOURDIEU, Pierre. Espaço social e poder simbólico. In: .Coisas Ditas. São Paulo: Brasiliense, 2004. p. 149-168.

BRASIL, Marta Maria da Silva. Edição de alguns poemas éditos e inéditos de Godofredo Filbo. 2006. Dissertação (Mestrado em Letras) - Programa de Pós-Graduação em Letras e Linguística, Instituto de Letras, Universidade Federal da Bahia, Salvador, 2006. Disponível em: $<$ http://www. bibliotecadigital.ufba.br/tde_busca/arquivo.php?codArquivo=451>.

BREFE, Ana Claudia Fonseca. O Museu Paulista:Affonso de Taunay e a memória nacional. 1917 1945. São Paulo: Editora Unesp; Museu Paulista, 2005.

CANDIDO, Antonio. Patrimônio interior. In: CAVALCANTI, Lauro (Org.). Modernistas na repartição. 2. ed. rev. Rio de Janeiro: Editora UFRJ; MinC-Iphan, 2000. p. 207-210.

CASTRO, Renato Berbert de. O historiador Francisco Borges de Barros. Revista do Instituto Geográfico e Histórico da Babia, Salvador, n. 87, p. 185-187, 1978.

Breviário da Academia de Letras da Babia: 1917-1994. 2. ed. Salvador: Conselho Estadual de Cultura, 1994.

CERAVOLO, Suely; SANTOS, Daisy C.Apontamentos sobre José Antonio do Prado Valladares: "um homem de museu”. Cadernos do Ceom: educação patrimonial, Chapecó, n. 26, p. 195-222, 2007.

COLEMAN, Laurence Vail. Directory of Museums in South America. Washington:American Association of Museums, 1929.

COUTINHO,Afrânio; SOUZA, J. Galante de (Org.). Enciclopédia de literatura brasileira, 2. Rio de Janeiro: FAE, 1981.

CRAVO, Mario. José Antônio do Prado Valadares. Lembrança do crítico e museólogo. In: $O$ desafio da escultura: a arte moderna na Bahia - 1940 a 1980. Salvador: Omar G., 2001.

DE LA PENHA, Guilherme M. S. M. et al. (Org.). O Museu Paraense Emílio Goeldi. São Paulo: Banco Safra, 1986

DIAS,André Luis Matteti. Profissionalização dos professores de Matemática na Bahia: as contribuições de Isaías Alves e de Martha Dantas. Letras e Artes, Ponta Grossa, v. 16, n. 2, p. 243-260, dez. 2008. Disponível em: <http://www.propesp.uepg.br/publicatio/hum/2008-2/Art.5.pdf >.Acesso em: 10 out. 2010.

FAUSTO, Boris. História do Brasil.4. ed. São Paulo: Edusp; FDE, 1996.

FIGUEIREDO, Paulo Augusto de. O Estado Novo e o Homem Novo. Cultura Política, Rio de Janeiro, v. 1, n. 1, p. 133-138, mar. 1941.

FONSECA, Maria Cecilia Londres. Patrimônio em processo.Trajetória da política federal de preservação no Brasil. 2. ed. Rio de Janeiro: Editora UFRJ; MinC-Iphan, 2005.

FONSECA, Raimundo Nonato da Silva. "Fazendo fita": cinematógrafos, cotidiano e imaginário em Salvador: Salvador: Edufba; Centros de Estudos Baianos, 2002. (Centro de Estudos Baianos, 150). 
FREYRE, Gilberto. O que foi o 1. Congresso Afro-Brasileiro do Recife. In: . Novos Estudos Afro-Brasileiros. São Paulo: Civilização Brasileira, 1937. p. 348-352.

GOMES,Angela de Castro. Em família: a correspondência entre Oliveira Lima e Gilberto Freyre. In: (Org.). Escrita de si. Escrita da história. Rio de Janeiro: Editora FGV, 2004. p. 51-75.

HOLLANDA, Guy de. Recursos educativos dos museus brasileiros. Rio de Janeiro: CBPE/Onicom, 1958.

INFLUÊNCIA política sobre a evolução social, intelectual e artística do Brasil (XVII). Cultura Política, Rio de Janeiro, v. 2, n. 17, p. 341-342, jul. 1942.

LARA FILHO, Durval. Museu: de espelho do mundo a espaço relacional. 2006. Dissertação (Mestrado em Ciência da Informação) - Escola de Comunicações e Artes, Universidade de São Paulo, 2006.

LEITE, Rinaldo Cesar Nascimento. E a Babia civiliza-se... Ideais de civilização e cenas de anticivilidade em um contexto de modernização urbana. Salvador, 1912-1916. Dissertação (Mestrado em História) - Faculdade de Filosofia e Ciências Humanas,Universidade Federal da Bahia, Salvador, 1996.

LIMA, Solange Ferraz de; CARVALHO, Vânia Carneiro de. Cultura material em um museu de história: as formas espontâneas de transferência do provado. In: FIGUEIREDO, Betânia Gonçalves; VIDAL, Diana Gonçalves (Org.). Museus: dos gabinetes de curiosidades à museologia moderna. Belo Horizonte:Argumentum; Brasilia: CNPq, 2005. p. 85-110.

LOPES, Maria Margaret. O Brasil descobre a pesquisa científica: os museus e as ciências naturais no século XIX. São Paulo: Hucitec, 1997.

LOURENÇO, Maria Cecília França.Museus acolbem moderno. São Paulo: Edusp, 1999.

MISAN, Simona. A implantação dos museus bistóricos e pedagógicos do estado de São Paulo (1956-1973). 2005. Tese (Doutorado em História Social) - Departamento de História, Faculdade de Filosofia, Letras e Ciências Humanas, Universidade de São Paulo, São Paulo, 2005.

NAPOLITANO, Marcos. Cultura Brasileira. Utopia e massificação (1950-1980). São Paulo: Contexto, 2008.

PAES, Fábio;ANDRADE, Maíta (Org.). Babia de todos os fatos. Cenas da vida republicana 18891991. 2. ed. Salvador:Assembleia Legislativa, 1997.

PERES, Fernando da Rocha. Nota retroativa. In: Protesto contra a demolição da Sé, 1928. Salvador: Universidade Federal da Bahia, CEB-UFBA, 1987. (Centro de Estudos Baianos, 127).

PINHEIRO, Maria Lucia Bressan. Neocolonial, modernismo e preservação do patrimônio no debate cultural dos anos 1920 no Brasil. 2005. Tese (Livre-docência) - Departamento de História da Arquitetura e Estética do Projeto, Faculdade de Arquitetura e Urbanismo, Universidade de São Paulo, São Paulo, 2005.

RIBEIRO JUNIOR, Ademir. Parafernália das mães-ancestrais. As máscaras gueledé, os edan ogboni e a construção do imaginário sobre as "sociedades secretas" africanas no Recôncavo Baiano. 2008. Dissertação (Mestrado em Arqueologia) - Programa de Pós-Graduação em Arqueologia, Museu de Arqueologia e Etnologia, Universidade de São Paulo, São Paulo, 2008. 
ROMO, Anadelia. O que é que a Bahia representa? O Museu do Estado da Bahia e as disputas em torno da definição de cultura baiana. Afro-Asia, Salvador, n. 39, 115-152, 2009.

Brazil's living museum. Race, reform, and tradition in Bahia. Chapel Hill:The University of North Carolina Press, 2010.

SAMPAIO, Consuelo Novais. Poder E representação: o Legislativo da Bahia na Segunda República, 1930-1937. Salvador:Assembleia Legislativa-Assessoria de Comunicação Social, 1992.

50 anos de urbanização. Salvador da Bahia no século XIX. Rio de Janeiro:Versal, 2005.

SANTOS, Mariza Veloso Motta. O tecido do tempo: a ideia de patrimônio cultural no Brasil 19201970. 1992. Tese (Doutorado em Antropologia Social) - Programa de Pós-Graduação em Antropologia, Departamento de Antropologia, Instituto de Ciências Humanas, Universidade de Brasília, Brasília, 1992.

SCHWARTZMAN, Simon; BONEMY, Maria Bousquet; COSTA, Vanda M.R. Tempos de Capanema. Rio de Janeiro: Paz e Terra; São Paulo: Edusp, 1984.

SILVA, Aldo José Morais. Instituto Geográfico e Histórico da Babia. Origem e estratégias de consolidação institucional (1894-1930). 2006. Tese (Doutorado em História ) - Programa de Pós-Graduação em História, Faculdade de Filosofia e Ciências Humanas, Universidade Federal da Bahia, Salvador, 2006.

SILVA, Paulo Santos. Âncoras de tradição. Luta política, intelectuais e construção do discurso histórico na Bahia (1930-1949). Salvador: Edufba, 2000.

SILVA, Paulo Sergio da. A Constituição Brasileira de 10 de Novembro de 1937. Um retrato com luz e sombra. São Paulo: Editora Unesp, 2008.

SMITH, Robert C. José Antonio do Prado Valladares (1917-1959). The Hispanic American Historical Review, Durham, v. 40, n. 3, p. 435-438,Aug. 1960.

TRIGUEIROS, Florisvaldo dos Santos. Museus. Sua importância na educação do povo. Rio de Janeiro: Pongetti, 1956.

Museu e educação. 2. ed. Rio de Janeiro: Pongetti, 1958.

UZÊDA, Jorge Almeida. O aguaceiro da modernidade na cidade do Salvador (1935-1945). 2006. Tese (Doutorado em História Social do Brasil) - Programa de Pós-Graduação em História, Faculdade de Filosofia e Ciências Humanas, Universidade Federal da Bahia, Salvador, 2006.

VALLADARES, José. Breves considerações sobre o Museu do Estado. América, Salvador, v. 2, n. 7 , 1940.

. Casas históricas americanas. Revista do Instituto Geográfico e Histórico da Babia, Salvador, n. 72, p. 279-293, 1945.

Museus para o povo. Um estudo sobre museus americanos. Salvador: Museu do Estado da Bahia; Secretaria de Educação e Saúde, 1946a. (Publicações do Museu, 6).

Guia do visitante (Válido de Julho de 1946 a Junho de 1947). Salvador: Museu do Estado da Bahia; Divisão de Imprensa e Turismo do Departamento Estadual de Informações, [1946?b]. 
Bahia and Its Museum. Bulletin of the Pan American Union, Washington, v. 82, n. 8, p. 449458, 1948.

. A Galeria Abbott. Primeira pinacoteca da Bahia. Salvador: Museu do Estado da Bahia; Secretaria de Educação e Saúde, 1951a. (Publicações do Museu, 12).

Bêabá da Babia. Guia Turístico. Ilustrações e mapa de Carlos Thieré. Salvador: Livraria Turista, $1951 \mathrm{~b}$.

Artes maiores e menores. Salvador: Universidade da Bahia, 1957.

Estudos de Arte Brasileira. Salvador: Museu do Estado da Bahia, 1960. (Publicações do Museu, 15).

VIANA, Hélder do Nascimento. Os usos do popular: coleções, museus e identidades, na Bahia e em Pernambuco, do início do século à década de 1950. 2002. Tese (Doutorado em História Social) - Faculdade de Filosofia, Letras e Ciências Humanas, Universidade de São Paulo, São Paulo, 2002.

VILAÇA, Marcos Vinícios R. Apresentação. In:ANDRADE, Rodrigo Melo Franco de. Rodrigo $e o$ Sbpan: coletânea de textos sobre o patrimônio cultural. Rio de Janeiro: MinC, 1987.p. 5-6.

Artigo apresentado em 2/2011. Aprovado em 5/201 1. 